Anna Beatriz Grigolon

\title{
IMPACTOS DOS PADRÕES DE CRESCIMENTO ESPACIAL E DE TRANSPORTES NO ENTORNO DE PÓLOS GERADORES DE VIAGENS
}

Orientador:

Prof. Assoc. Antônio Nélson Rodrigues da Silva

Dissertação apresentada à Escola de Engenharia de São Carlos da Universidade de São Paulo, como parte dos requisitos para a obtenção do título de Mestre em Engenharia Civil: Planejamento e Operação de Sistemas de Transportes. 
Ficha catalográfica preparada pela Seção de Tratamento da Informação do Serviço de Biblioteca - EESC/USP

G857i

Grigolon, Anna Beatriz

Impactos dos padrões de crescimento espacial e de transportes no entorno de pólos geradores de viagens / Anna Beatriz Grigolon ; orientador Antônio Nélson Rodrigues da Silva. -- São Carlos, 2007.

Dissertação (Mestrado-Programa de Pós-Graduação em Engenharia de Transportes e Área de Concentração em Planejamento e Operação de Sistemas de Transportes) -Escola de Engenharia de São Carlos da Universidade de São Paulo, 2007 .

1. Planejamento urbano e de transportes. 2. Pólos geradores de viagens. 3. Análise espacial. 4. ESDA.

5. Modelos de simulação urbana. 6. Autômatos celulares. I. Título. 
Aos meus pais, Lisete e José Carlos, pelo amor e pela minha formação intelectual e moral. 



\section{Agradecimentos}

À minha mãe, Lisete, pelo amor incondicional, amizade e incentivo. Pelo ensinamento maior de vida, para o SER, antes do TER.

Ao meu pai, José Carlos, que apesar de ter partido, possui grande parte dessa conquista, por acreditar no meu potencial e sempre falar de nós "com a boca cheia" de orgulho.

Aos meus irmãos, Lisanne e Gustavo, por sempre torcerem para que tudo de melhor aconteça em minha vida.

Ao meu sobrinho, João Pedro, que apesar de não saber ainda, nos ensinou que devemos valorizar cada dia das nossas vidas.

À minha tia, madrinha e segunda mãe, Malú, pelo carinho e por estar sempre presente.

Ao Ivan, por todos esses anos de convivência, amor e paciência, e por ter me ajudado na elaboração da parte gráfica deste trabalho.

À minha sogra e amiga, Ana Maria, pelo apoio e pela torcida.

Em especial, ao meu orientador, Antônio Nélson Rodrigues da Silva, pela oportunidade de crescimento e por toda a rica experiência que adquiri durante esses dois anos de convivência.

Ao Prof. Archimedes Azevedo Raia Jr., responsável pelo meu desenvolvimento acadêmico durante a graduação, pela recomendação ao mestrado e contribuição no Exame de Qualificação, e pela amizade construída ao longo desses anos.

Ao Prof. José Alberto Quintanilha, pelas contribuições no Exame de Qualificação.

A todos os professores e funcionários do Departamento de Transportes e do Cetepe.

Aos "irmãos acadêmicos", em especial, ao Gustavo, pela amizade e por ter estado sempre ao meu lado. Andréa Júlia, Vanessa Santos, Alexandra, Michael, Fabíola, Renata, Vanessa Yuassa, Leonardo, Simone e Marcela.

Aos amigos do Departamento de Transportes, pela agradável convivência durante esses dois anos.

Às minhas amigas que eu morei em São Carlos e que estão sempre em meu pensamento: Maria Claudia, Alice, Karlinha, Carol Cavalheiro, Maíra, Jú, Vivian, Paulinha, Thaís Araújo e Thaís Busquim.

Pelos momentos de descontração, que também foram importantes para a finalização desse trabalho, às minhas amigas queridas Dani e Jessica, e aos amigos: Fer Anjo, Rô, Fer Mendes, Perez, Samuca, Bárbara, Edu, Pri, Gabriel, Renata, Pedro, Mayra, Samantha, Gabi.

Aos amigos da DHL, pela convivência diária e palavras de incentivo.

À Prefeitura Municipal de Campinas, pela cessão dos dados necessários para esta pesquisa, e à Heloni Martinez, pela ajuda na obtenção desses dados.

Ao Conselho Nacional de Desenvolvimento Científico e Tecnológico (CNPq), pelo apoio financeiro sem o qual este trabalho não teria sido realizado.

E a todos aqueles que, direta ou indiretamente, colaboraram para este trabalho. 

"Se eu enxerguei mais longe foi por estar de pé sobre os ombros de Gigantes"

Isaac Newton 



\section{Resumo}

GRIGOLON, A. B. Impactos dos Padrões de Crescimento Espacial e de Transportes no Entorno de Pólos Geradores de Viagens. Dissertação (Mestrado) - Escola de Engenharia de São Carlos, Universidade de São Paulo, São Carlos, 2007.

O desenvolvimento das cidades freqüentemente propicia o aparecimento de empreendimentos de grande porte que, juntamente com o aumento da população e dos veículos, causam impactos nos sistemas de transportes. Dado que há fortes indícios que a localização e o porte destes empreendimentos, aqui denominados de Pólos Geradores de Viagens (ou PGVs), seja influenciado pela presença de outros PGVs, o objetivo deste trabalho foi avaliar esta hipótese em uma cidade média brasileira, através de duas vertentes da Análise Espacial: a estatística espacial e a modelagem espacial baseada na comparação de informações oriundas de diferentes entidades espaciais. Foram utilizados conceitos de Análise Exploratória de Dados Espaciais, tais como o índice e o diagrama de espalhamento de Moran, para a delimitação de regiões similares, divididas de modo a indicar pontos de associação espacial, em relação a uma variável analisada. Em seguida, a modelagem espacial foi feita com uma adaptação da técnica de Cellular Automata, usando Redes Neurais Artificiais. Dois modelos foram propostos e aplicados em um estudo de caso na cidade de Campinas, São Paulo, com base em diferentes variáveis. No primeiro modelo, somente variáveis representativas da ocupação comercial foram consideradas, enquanto que, no segundo modelo, foram introduzidas também variáveis caracterizando a infra-estrutura viária. Os resultados permitem observar um bom desempenho dos modelos, em particular na fase de validação. As projeções futuras obtidas com os modelos, no entanto, não parecem caracterizar adequadamente o surgimento, que seria naturalmente esperado, de novos pólos comerciais ao redor dos Shopping Centers estudados. Essa limitação foi surpreendentemente mais evidente no caso do modelo com variáveis de infra-estrutura viária.

Palavras-chave: pólos geradores de viagens, análise espacial, ESDA, modelos de simulação urbana, autômatos celulares, planejamento urbano e de transportes. 

GRIGOLON, A. B. Impacts of Transportation and Spatial Growth Patterns Around Major Trip Generators. Dissertation (Master) - São Carlos School of Engineering, University of São Paulo, São Carlos, 2007.

The development of cities often leads to the development of large business areas. Those areas, together with the growth of population and vehicles figures in the entire urban area, produce several impacts in the transportation systems. Given the evidences that the location and size of new Trip Generators (TG's) may be strongly influenced by existing TG's, the objective of this study was to evaluate that hypothesis in a Brazilian medium-sized city. Two branches of spatial analysis were explored in the present study while dealing with different sources of spatial information. They were: spatial statistics and spatial modeling. Firstly, concepts of Exploratory Spatial Data Analyses (ESDA), like Moran's I index and scatterplot, were used to characterize regions of similar behavior in terms of particular variables. Secondly, spatial modeling was carried out using Cellular Automata concepts and Artificial Neural Networks. Two models were proposed and applied in a case study carried out in the city Campinas, São Paulo, based on different variables. In the first model, only variables representing commercial land use were considered, while in the second model variables representing the transportation infrastructure supply were also added. The results found indicate a good performance of the models, particularly in the validation process. Their future projections, however, are apparently not able to represent the development of new commercial activities that would be naturally expected around the shopping malls investigated. Although that limitation was observed in both models, it was surprisingly more evident in the case of the model with variables of transportation infrastructure.

Keywords: trip generators, spatial analysis, ESDA, urban simulation models, cellular automata, urban and transportation planning. 



\section{Sumário}

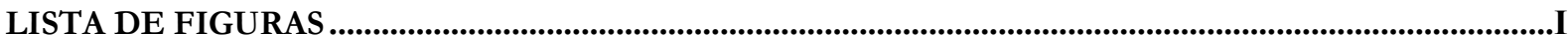

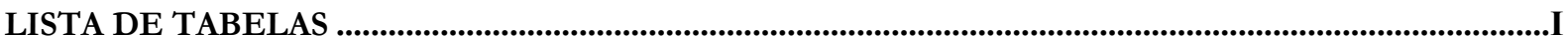

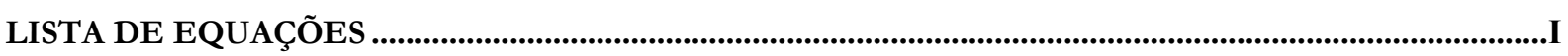

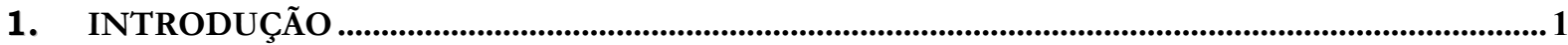

1.1. CARACTERIZAÇÃO DO PROBLEMA E JUSTIFICATIVA DA PESQUISA …............................................. 1

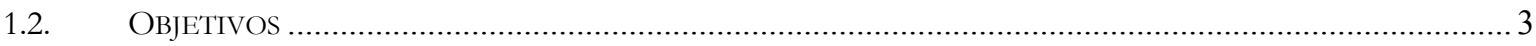

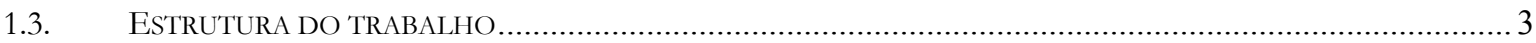

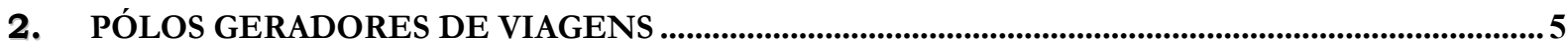

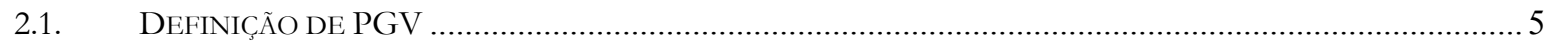

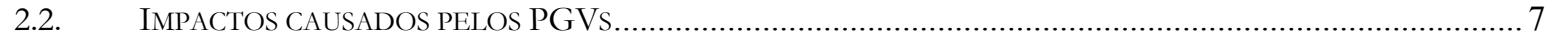

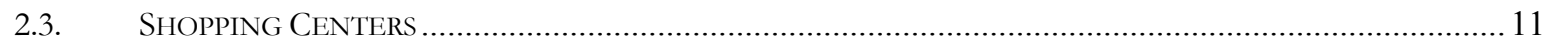

2.4. ÁREA DE INFLUÊNCIA E PADRÕES DE OCUPAÇÃO DO SOLO DE UM PGV …..................................... 13

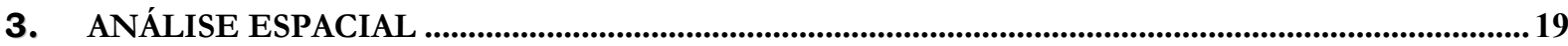

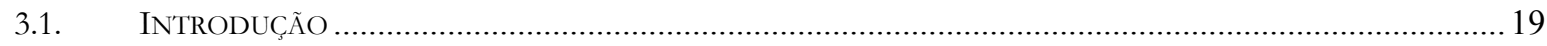

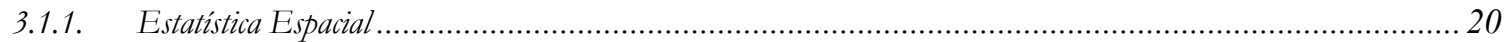

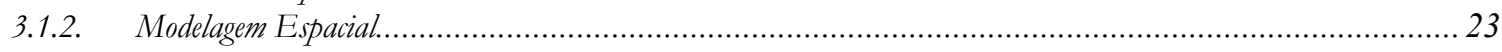

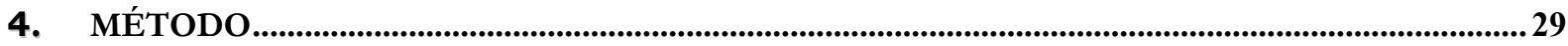

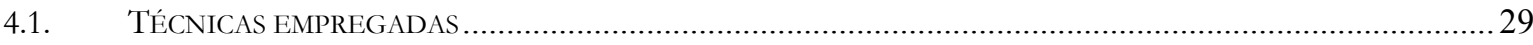

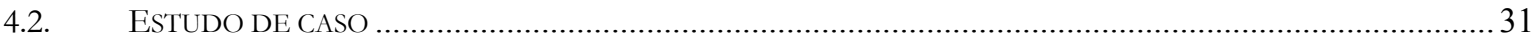

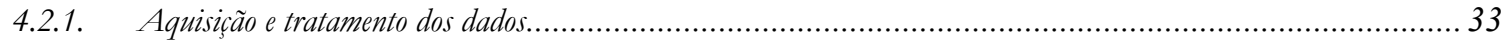

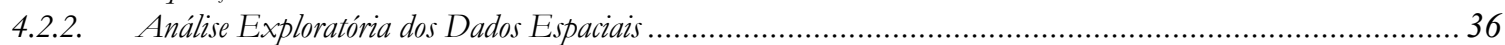

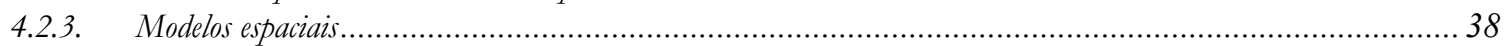

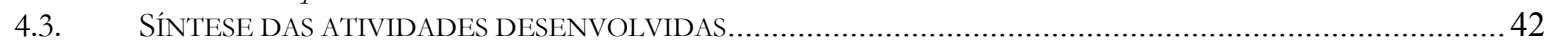

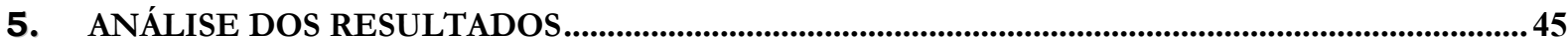

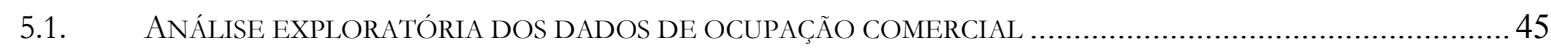

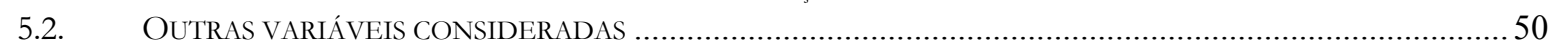

5.3. MODELO I - RESULTADOS DA VALIDAÇ̃̃o PARA O PERÍODO 1998-2003 …............................................51

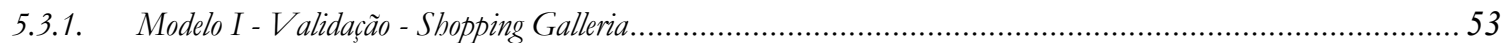

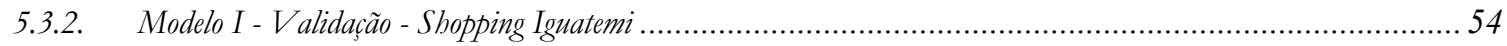

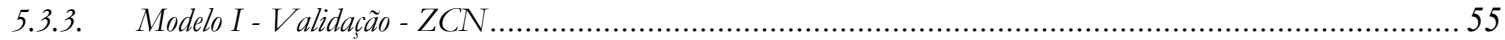

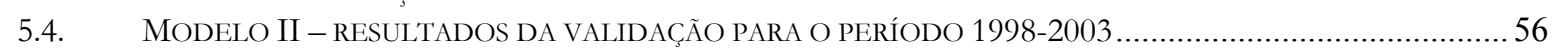

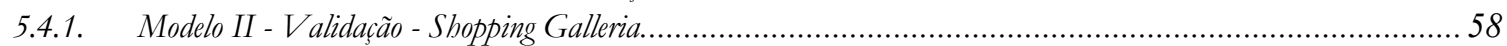

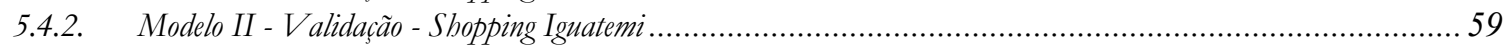

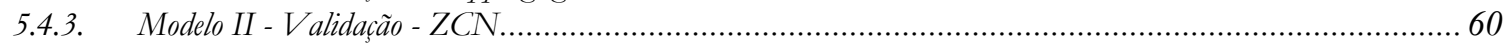

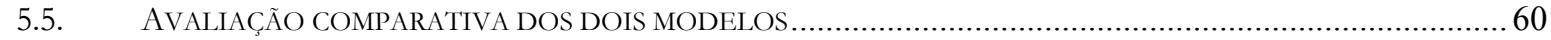

5.6. MODELO I - RESULTADOS DA PREVISÃO PARA O PERÍODO 2004-2009 …..............................................65

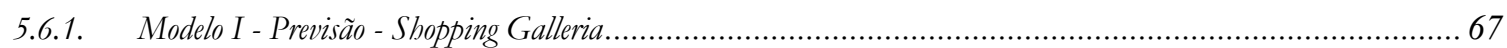

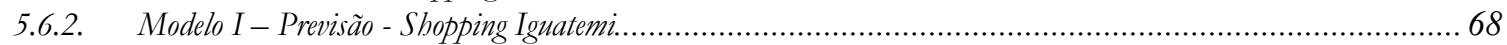

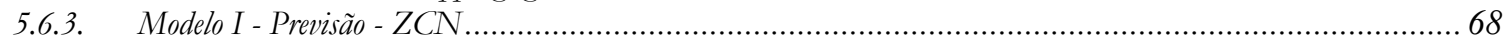

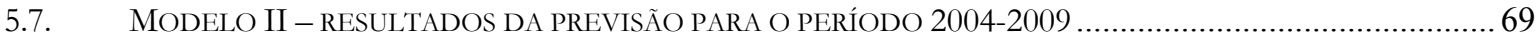

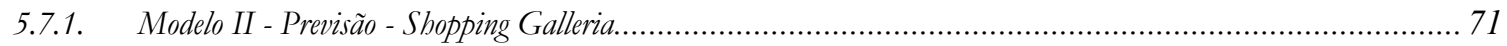

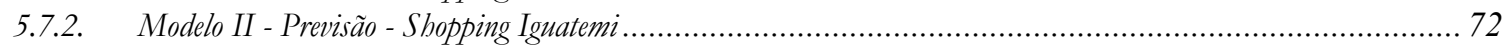

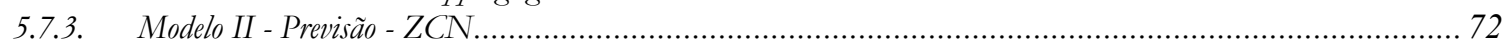

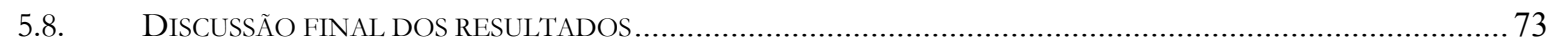

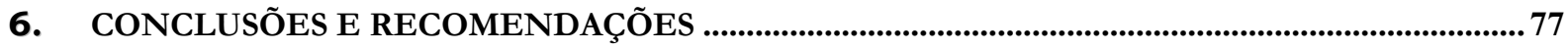

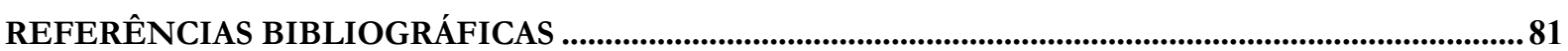





\section{Lista de figuras}

Figura 2.1: Teorias sobre os padrões de ocupação espacial dos PGV s.................................................................. 16

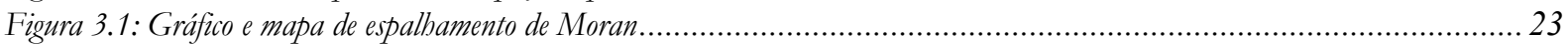

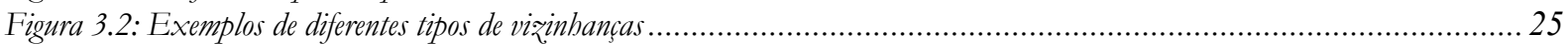

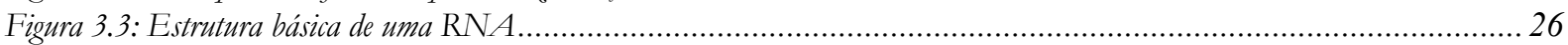

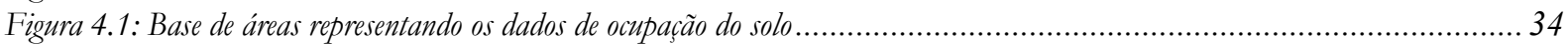

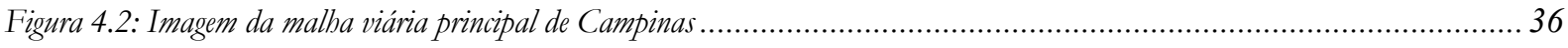

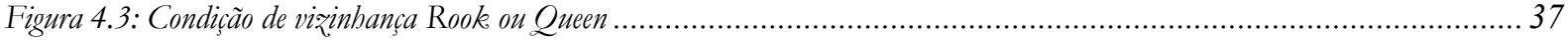

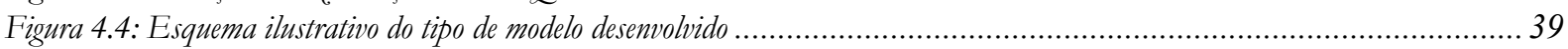

Figura 5.1: Box map representando a proporção de uso comercial até 1979 ..........................................................................47

Figura 5.2: Box map representando a proporção de uso comercial de 1980 a 1985 .......................................................... 48

Figura 5.3: Box map representando a proporção de uso comercial de 1986 a 1991 .................................................................. 48

Figura 5.4: Box map representando a proporção de uso comercial de 1992 a 1997 ............................................................ 49

Figura 5.5: Box map representando a densidade proporção de uso comercial de 1998 a 2003............................................... 49

Figura 5.6: Ocupação comercial real x estimada pelo Modelo I no período 1998-2003 ...................................................52

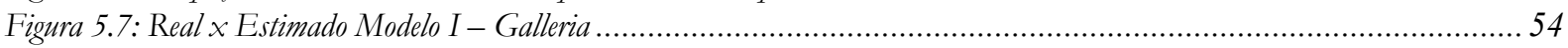

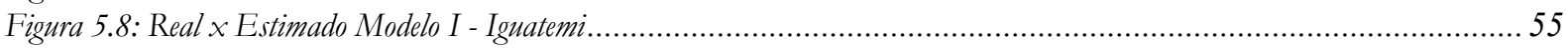

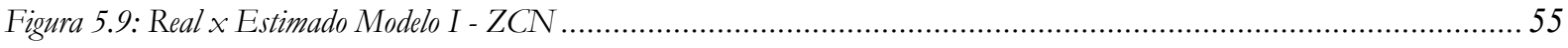

Figura 5.10: Ocupação comercial real x estimada pelo Modelo II no período 1998-2003 ...................................................5

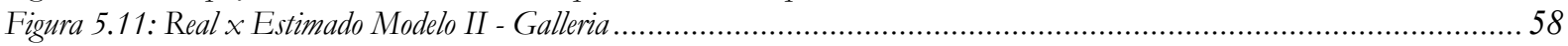

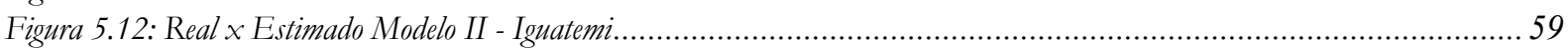

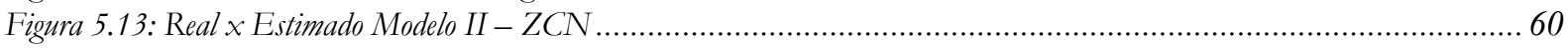

Figura 5.14: Comparação da situação real x estimada pelo Modelo I no período 1998-2003.............................................. 61

Figura 5.15: Comparação da situação real x estimada pelo Modelo II no período 1998-2003 ...........................................61

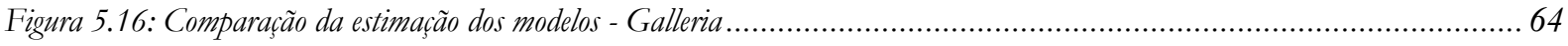

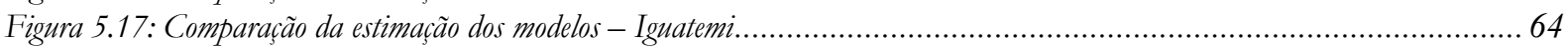

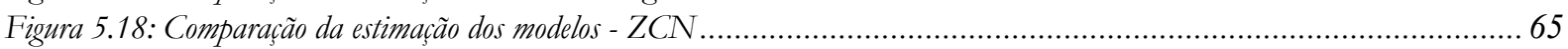

Figura 5.19: Ocupação comercial real x prevista pelo Modelo I no período 2004-2009.....................................................6 66

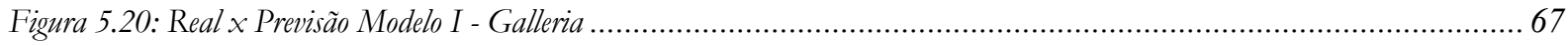

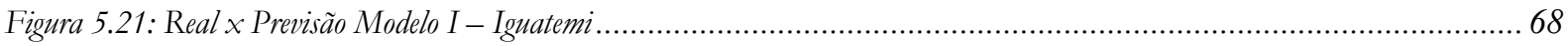

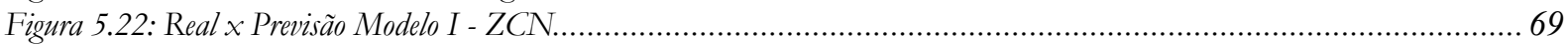

Figura 5.23: Ocupação comercial real x prevista pelo Modelo II no período 2004-2009........................................................... 70

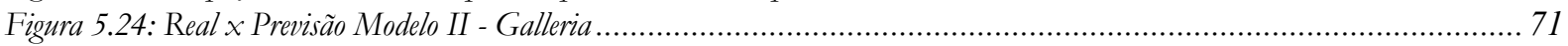

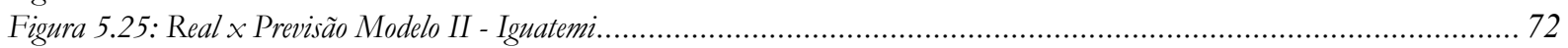

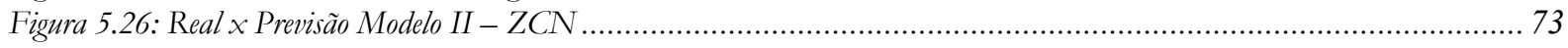

Figura 5.27: Número de ocupações por proporção de uso comercial para o Shopping Galleria - Modelo I .................................. 74

Figura 5.28: Número de ocupações por proporção de uso comercial para o Shopping Iguatemi-Modelo I................................. 74

Figura 5.29: Número de ocupações por proporção de uso comercial para o Shopping Galleria-Modelo II................................... 75

Figura 5.30: Número de ocupações por proporção de uso comercial para o Shopping Iguatemi-Modelo II................................. 75 



\section{Lista de tabelas}

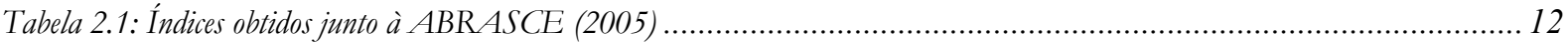

Tabela 2.2: Alguns trabalhos relacionados ao estudo dos Shopping Centers e de seus impactos no meio urbano, no Brasil................ 13

Tabela 2.3: Área de influência e percentuais de viagens (modificado - Portugal e Goldner, 2003).......................................15

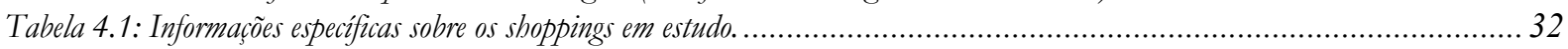

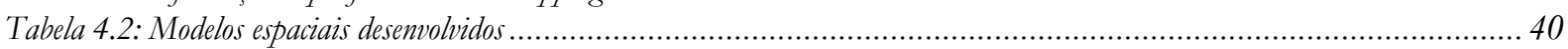

Tabela 4.3: V ariáveis utilizadas em cada modelo e em cada fase da modelagem por redes neurais............................................41

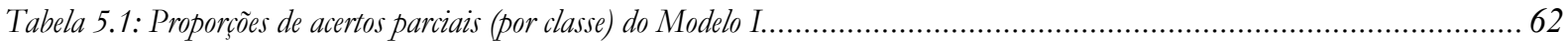

Tabela 5.2: Proporções de acertos parciais (por classe) do Modelo II .......................................................................63

\section{Lista de equações}

Equação 3.1: Índice de Moran (global)..... 



\section{Introdução}

Neste capítulo se encontram algumas características do problema estudado, que se refere aos Pólos Geradores de Viagens e seus padrões de expansão em zonas urbanas, com as justificativas da pesquisa, bem como o objetivo e a estrutura deste trabalho.

\subsection{Caracterização do problema e justificativa da pesquisa}

As cidades brasileiras, nas últimas décadas, passaram por processos de crescimento intenso, ligados à dinamização das atividades econômicas e às migrações populacionais. Associado a isto, sofreram outros impactos, como a reconstrução física e adaptações do sistema viário, quase sempre justificadas como alternativas capazes de proporcionar uma redistribuição de acessibilidade, entendida nesse contexto como a capacidade de movimentação entre pontos de origem e destino. O que ocorreu de fato é que o automóvel acabou modelando as cidades deste século, reformulando a noção de espaço e distância, além de modificar os hábitos das pessoas (Scarlato, 1989). 
As maiores cidades do Brasil, tal como ocorre com muitos países em desenvolvimento, foram transformadas, em décadas recentes, em espaços eficientes para o automóvel. A frota de automóveis cresceu substancialmente, alardeada como única alternativa eficiente de transporte para os cidadãos de mais elevados níveis de renda. O sistema viário sofreu ampliações e adaptações, órgãos públicos foram implantados para garantir boas condições de fluidez para o automóvel. Dessa maneira, formou-se a base para a implantação de uma cultura voltada para este modo de transporte, capaz de consumir um nível muito elevado de recursos (ANTP, 1999).

O Shopping Center pode ser considerado como um dos "ícones" da cultura ao automóvel, uma vez que, devido à sua localização, na maioria das vezes nas zonas periféricas da cidade, e à disponibilidade de locais para estacionamento, fazem com que este modo de transporte seja ainda mais utilizado.

Assim, os Shopping Centers, bem como qualquer empreendimento que tenha a mesma característica de atração ou produção de viagens (supermercados, escolas, hospitais etc.) podem ser considerados como "Pólos Geradores de Viagens" (PGVs), uma vez que, ao concentrar em um único local várias atividades específicas, geram grande quantidade de viagens.

Dessa forma, observa-se uma forte relação entre o empreendimento gerador de viagens e as características de uso e ocupação do solo, uma vez que, ao possibilitar o acesso por meio da infra-estrutura de transportes, outras atividades podem ser atraídas para as regiões vizinhas ao PGV.

É justamente neste ponto que o presente trabalho se baseia, tentando avaliar a hipótese de que os PGVs existentes possam influenciar na localização e atração de novos PGVs para as regiões vizinhas. Tendo em vista que um dos problemas enfrentados pelos planejadores públicos 
é a falta de ferramentas para prever e gerenciar o crescimento das áreas urbanas, a contribuição deste trabalho está em apresentar instrumentos que sejam eficazes para as estratégias de planejamento.

A previsão dos impactos dos padrões de crescimento espacial e de transportes no entorno de Pólos Geradores de Viagens pode, dessa forma, ser um instrumento útil no processo de tomadas de decisões para o planejamento urbano e de transportes, mesmo que as ferramentas aqui utilizadas, dentro dos conceitos da Estatística Espacial e da Modelagem Espacial, ainda não estejam plenamente difundidas no país.

\subsection{Objetivos}

- Modelar os padrões de crescimento dos PGVs utilizando técnicas de análise e modelagem espacial para previsão de impactos em transportes, em cidades médias brasileiras.

- Avaliar como a localização e o porte destes empreendimentos influenciam a implantação de outros PGVs.

- Contribuir para a investigação do fenômeno em cidades com características similares à estudada.

\subsection{Estrutura do trabalho}

No capítulo 2 são apresentados os resultados de uma revisão bibliográfica referente a Pólos Geradores de Viagens, em especial sobre os Shopping Centers. No capítulo 3 são discutidos alguns conceitos básicos sobre duas vertentes da Análise Espacial: a Estatística Espacial e a Modelagem Espacial. 
No capítulo 4 é apresentado o método adotado nesta pesquisa, em que são descritas as etapas de tratamento e formatação dos dados, análise exploratória dos dados espaciais e a etapa de modelagem, com detalhes sobre o modelo espacial que foi desenvolvido.

Os resultados e análises obtidos por meio da aplicação do método proposto são apresentados no capítulo 5 e no capítulo 6 estão as conclusões e recomendações para trabalhos futuros. Este trabalho finaliza com a apresentação das referências bibliográficas. 


\section{Pólos Geradores de Viagens}

Neste capítulo é apresentada inicialmente uma discussão sobre o conceito de Pólo Gerador de Viagens (PGV), seguida de uma relação sobre os principais impactos causados com a implantação de um PGV e algumas metodologias de previsão desses impactos. Após, há um destaque para os Shopping Centers, que motivaram o desenvolvimento deste estudo, seguido da discussão sobre a sua área de influência e os padrões de ocupação do solo de um PGV.

\subsection{Definição de PGV}

Os Pólos Geradores de Viagem (PGVs) são, segundo DENATRAN (2001) e CET(1983), empreendimentos de grande porte que atraem ou produzem grande número de viagens, causando reflexos negativos na circulação viária em seu entorno imediato e, em certos casos, prejudicando a acessibilidade de toda a região, além de agravar as condições de segurança de veículos e pedestres. 
Já em Portugal e Goldner (2003), a definição trata dos impactos no que diz respeito à produção de viagens: os PGVs são locais ou instalações de distintas naturezas, que desenvolvem atividades de porte e escala capazes de produzir um número significativo de viagens.

Em Grando (1986), são observados aspectos de circulação, fluidez e segurança do tráfego e acessibilidade: PGVs são empreendimentos que, mediante a oferta de bens e/ou serviços, geram ou atraem grande número de viagens, causando impactos na circulação de tráfego do entorno, tanto em termos de acessibilidade e fluidez do tráfego, geralmente com repercussões em toda uma região, quanto em termos da segurança dos veículos e pedestres.

O conceito de Pólos Geradores de Viagens (PGVs) foi incorporado recentemente na metodologia de análise de impacto das atividades urbanas sobre o comportamento das redes viárias, produto das novas visões que se introduzem nas técnicas de Planejamento. Atualmente tem sido adotado devido às características do processo de urbanização e renovação urbana, onde começam a aparecer atividades que modificam substancialmente o comportamento do trânsito na sua área de influência e que requerem uma avaliação pontual para, por um lado, possibilitar as medidas de gestão da demanda de transportes e, por outro, impor controles e/ou exigências adicionais aos encarregados do desenvolver essas atividades (Espejo, 2001).

O seu controle torna-se importante como forma de minimizar ou eliminar os impactos indesejáveis que possam ter sobre o transporte e o trânsito da sua área de influência e que são causas importantes das más condições de circulação nas grandes cidades brasileiras (ANTP, 2005). 


\subsection{Impactos causados pelos PGVs}

De acordo com DENATRAN (2001), a implantação e operação de pólos geradores de viagens comumente causa impactos na circulação viária, requerendo uma abordagem sistêmica de análise e tratamento que leve em conta simultaneamente seus efeitos indesejáveis na mobilidade e acessibilidade de pessoas e veículos e o aumento da demanda de estacionamento em sua área de influência.

Os impactos sobre a circulação ocorrem quando o volume de tráfego nas vias adjacentes e de acesso ao pólo gerador de viagem se eleva de modo significativo, devido ao acréscimo de viagens gerado pelo empreendimento, reduzindo os níveis de serviço e de segurança viária na área de influência. Tal situação produz muitos efeitos indesejáveis, tais como:

- Congestionamentos, que provocam o aumento do tempo de deslocamento dos usuários do empreendimento e daqueles que estão de passagem pelas vias de acesso ou adjacentes, além do aumento dos custos operacionais dos veículos utilizados;

- Deterioração das condições ambientais da área de influência do pólo gerador de viagem, a partir do aumento dos níveis de poluição, da redução do conforto durante os deslocamentos e do aumento do número de acidentes, comprometendo a qualidade de vida dos cidadãos;

- Conflitos entre o tráfego de passagem e o que se destina ao empreendimento e dificuldade de acesso às áreas internas destinadas à circulação e ao estacionamento, com implicações nos padrões de acessibilidade da área de influência imediata do empreendimento. 
Com relação ao aumento da demanda de estacionamento, os efeitos serão indesejáveis se o projeto do pólo gerador de viagem deixar de prever um número suficiente de vagas de estacionamento em seu interior, conduzindo o usuário ao uso irregular da via pública e, conseqüentemente, restringindo a capacidade da via, visto que os veículos passam a ocupar espaços até então destinados à circulação, reduzindo mais a fluidez do tráfego (DENATRAN, 2001).

É possível estabelecer uma forte relação entre o empreendimento gerador de viagens e as seguintes variáveis:

- Características do uso e ocupação do solo, através do desenvolvimento de atividades;

- Características socioeconômicas da população que se desloca para o empreendimento;

- Geração de viagens com conseqüente geração de tráfego e de trânsito.

As variáveis comumente utilizadas para a classificação de PGVs consistem basicamente na área construída e número de vagas para estacionamento, o que possibilita estimar a geração de viagens causada exclusivamente pelo empreendimento. Observa-se ainda um avanço na legislação paulista ao considerar impactos ambientais e urbanos causados por determinados empreendimentos, devendo tais empreendimentos serem compatibilizados à sua área de inserção (Kneib, 2004).

Os impactos causados nos padrões de ocupação do solo quando do surgimento de um PGV, qualquer que seja o porte da cidade, são, em curto prazo, relacionados somente a aspectos 
relativos à sua implantação. No entanto, a médio e longo prazo, o entorno do PGV passa a ser modificado, devido a sua influência em todos os tipos de usos. Por isso, para a previsão desses impactos, deve-se levar em conta aspectos relacionados ao uso de solo, ao sistema viário e ao transporte, tanto público como privado.

Para o sistema de transporte privado os impactos são, em suma, referentes ao tempo de viagem e à qualidade do trajeto. O primeiro é devido ao tráfego adicional que será gerado e o segundo, aos impactos nas condições físicas das vias que essa alteração de fluxo de veículos causará. Os mesmos impactos no sistema privado devem ser observados quando se analisa o transporte público. No entanto, devem-se adicionar os impactos na qualidade do serviço, uma vez que a demanda por transporte aumentará no itinerário que passa pelo PGV. Além disso, se o PGV estiver localizado em uma área já com grande atração de viagens, como próximo à Zona Central de Negócios, a demanda adicional poderia causar atrasos na linha e também lotação dos veículos.

Os impactos causados pelos PGVs nos sistemas viários e de transportes, associados ao grande número de empreendimentos e à diversidade de projetos e ambientes urbanos, estimularam o desenvolvimento de metodologias de previsão de impacto, inicialmente nos EUA e Europa, e, a partir da década de 1980, no Brasil (Portugal e Goldner, 2003). Segundo Giustina e Cybis (2003), as principais metodologias são as seguintes:

- Departamento de Transportes dos Estados Unidos da América;

- Institute of Transportation Engineers - ITE;

- Metodologia Espanhola;

- Companhia de Engenharia de Tráfego - CET - SP; 
- Metodologia de Grando;

- Metodologia aplicada em Porto Alegre.

Segundo Kneib (2004), essas metodologias consideram os impactos no sistema viário e na circulação, que são instrumentos de extrema importância para o planejamento operacional do sistema de transportes, o que possibilita aos gestores a adoção de medidas mitigadoras e compensatórias contra os possíveis impactos negativos decorrentes da implantação de um empreendimento, nos sistemas viário e de transporte. Entretanto, outros impactos devem ser considerados, pois a amplitude dos impactos originados pela implantação de um novo PGV vai além dos impactos ditos diretos, abordados nas metodologias conhecidas. Devem ainda ser considerados os impactos ditos indiretos, que são aqueles que influenciam a acessibilidade, alterando os padrões de uso e ocupação do solo, que podem contribuir com um número significativo de viagens.

Esta pesquisa não se restringe ao emprego dos métodos acima, uma vez que seu objetivo difere ligeiramente daquele observado na maioria dos estudos, que são em geral realizados para avaliar se a rede viária circunvizinha aos empreendimentos possui capacidade para absorver o tráfego gerado com um nível de serviço aceitável. No caso desta pesquisa, o objetivo inclui a avaliação da forma como a localização e o porte destes empreendimentos influencia a implantação de outros PGVs. Para tanto, o foco principal do trabalho serão os Shopping Centers. 


\subsection{Shopping Centers}

Surgidos no início da década de 50 nos Estados Unidos, os centros comerciais conhecidos como Shopping Centers (SC) são empreendimentos que oferecem, em espaço compartilhado, produtos e serviços diversos, além de atividades de lazer e entretenimento. Estas características conferem aos SC um grande poder atrativo, provocando um intenso movimento de veículos e pedestres em suas imediações, podendo causar desequilíbrios entre a oferta e a demanda de espaço viário nestas áreas (Ary, 2002).

O aspecto marcante nos SC não é o aparecimento de uma inovação de caráter físico e sim ganhos de eficiência associados a uma aparentemente simples realocação de fatores de produção. No Brasil, que tem apresentado elevadas taxas de urbanização, são encontrados vários SC implantados ou em fase de construção, que, pelo vulto dos investimentos necessários e o grau de irreversibilidade da tomada de decisão, demonstram ser estratégica a determinação de suas localizações. Um aspecto não menos estratégico e que tem sido pouco analisado é o impacto que os SC provocam no seu entorno em nível de uso do solo e nas modificações sócio-negociais no território (Masano, 1993).

A afluência de novos produtos e a consolidação de hábitos de consumo encontrariam expressão nas novas áreas de compras de padrão sofisticado, conhecidas como Shopping Centers. Com isso, presenciou-se, na década de 80, uma proliferação destes tipos de equipamentos, numa intensidade violenta tanto na capital paulista, como no interior e em outros centros urbanos do país (Vargas, 1993a). 
Segundo dados obtidos junto à ABRASCE (Associação Brasileira de Shopping Centers), a Indústria de SC em 2005 conta com 262 shoppings, sendo 241 em operação e 21 em construção. Em 1983, somente $15 \%$ dos empreendimentos estavam no interior do país. Hoje, este percentual se elevou para $49 \%$. As vendas dos shoppings em 2004 representaram $18 \%$ do faturamento de todo o varejo nacional, excluídos os setores automotivo e de derivados de petróleo. A indústria de SC vem demonstrando grande vitalidade, contribuindo para o progresso da qualidade de vida no Brasil e desempenhando importante papel na economia, como geradora de cerca de 484.110 empregos diretos e com expressiva integração com a comunidade. Alguns índices podem ser vistos na Tabela 2.1 .

Tabela 2.1: Índices obtidos junto à ABRASCE (2005)

\begin{tabular}{|c|c|c|c|}
\hline ANO & Número de Shoppings & $\begin{array}{c}\text { Faturamento do Setor } \\
\text { (R \$ bilhões) }\end{array}$ & $\begin{array}{c}\text { Tráfego de pessoas } \\
\text { (milhões de pessoas mês) }\end{array}$ \\
\hline 2000 & 230 & 23.0 & 125 \\
\hline 2001 & 240 & 25.3 & 135 \\
\hline 2002 & 252 & 27.9 & 160 \\
\hline 2003 & 254 & 31.6 & 175 \\
\hline 2004 & 257 & 36.6 & 185 \\
\hline
\end{tabular}

No trabalho de Masano (1993) foi observado que à medida que as cidades crescem ocorre descentralização da atividade comercial, quando então aquelas zonas centrais tendem, via de regra, a perder a vitalidade que é retratada numa diminuição no valor de troca do solo. Por outro lado, a implantação comercial em novas áreas, como no caso dos SC, cria uma valorização e modificação do uso do entorno. Considerando-se que o município de São Paulo é o maior em número de habitantes e o mais desenvolvido do país, e que, além disso, registra anomalias inerentes a uma péssima distribuição de renda, o estudo da implantação dos seus PGVs deve contribuir para uma reflexão não só em nível municipal como nacional. A Tabela 2.2 mostra uma relação de alguns trabalhos relacionados ao estudo dos Shopping Centers e de seus impactos no meio urbano, em diversos locais do país. 
Tabela 2.2: Alguns trabalhos relacionados ao estudo dos Shopping Centers e de seus impactos no meio urbano, no Brasil

\begin{tabular}{|l|l|}
\hline AUTOR(ES) & TÍTULO DO TRABALHO \\
\hline Grando (1986) & $\begin{array}{l}\text { A interferência dos pólos geradores de tráfego no sistema viário: } \\
\text { análise e contribuição metodológica para Shopping Centers. }\end{array}$ \\
\hline Impacto de Shopping Centers. \\
\hline Labhouet e Bruna (1991) & Atividade terciária e o espaço urbano: Shopping Center \\
\hline Vargas (1993a) & $\begin{array}{l}\text { Shopping Centers: novas relações entre a atividade comercial e o } \\
\text { espaço urbano. }\end{array}$ \\
\hline Vargas (1993b) & Comércio: localização estratégica ou estratégia na localização? \\
\hline Masano (1993) & $\begin{array}{l}\text { Os Shopping Centers e suas relações físico-territoriais e sócio- } \\
\text { negociais no município de São Paulo. }\end{array}$ \\
\hline Goldner e Portugal (1993) & $\begin{array}{l}\text { Metodologia de Avaliação de Impactos de Tráfego de Shopping } \\
\text { Centers: Uma Abordagem Multimodal. }\end{array}$ \\
\hline Bienenstein (1993) & Capital e Espaço Urbano: O Exemplo do Shopping Center. \\
\hline Frúgoli Jr. (1998) & Os Shopping Centers e o impacto nas cidades de médio porte. \\
\hline Montessoro (2000) & Os Shopping Centers e as estratégias de localização. \\
\hline Ary (2002) & $\begin{array}{l}\text { Análise da demanda de viagens atraídas por Shopping Centers em } \\
\text { Fortaleza. }\end{array}$ \\
\hline Portugal e Goldner (2003) & $\begin{array}{l}\text { Estudo dos Pólos Geradores de Viagens e de seus impactos nos } \\
\text { sistemas viários e de transportes. }\end{array}$ \\
\hline Melo Jr. e Monetti (2004) & $\begin{array}{l}\text { A importância na escolha do local de implantação para um } \\
\text { Shopping Center. }\end{array}$ \\
\hline Kneib (2004) & $\begin{array}{l}\text { Caracterização de empreendimentos geradores de viagens: } \\
\text { contribuição conceitual à análise de seus impactos no uso, } \\
\text { ocupação e valorização do solo urbano. }\end{array}$ \\
\hline Grigolon e Silva (2006) & $\begin{array}{l}\text { Impactos dos padrões de ocupação do solo no entorno de Pólos } \\
\text { Geradores de Viagens. }\end{array}$ \\
\hline Yheng, Li e Yu (2005) & A GIS approach to shopping mall location selection. \\
\hline $\begin{array}{l}\text { Optimizing the distribution of Shopping Centers with parallel genetic } \\
\text { algorithm. }\end{array}$ \\
\hline
\end{tabular}

\section{4. Área de influência e padrões de ocupação do solo de um PGV}

A área de influência, de acordo com Silveira (1991), representa a delimitação física do alcance do atendimento da maior parte de sua clientela. Da mesma forma que em Grando (1986), a área de influência de um empreendimento gerador de viagem específico, o Shopping Center (SC), é a área de mercado geograficamente definida, em que um conjunto varejista atrai a maior parte de seus clientes. Assim, a área de influência é um dado que permite avaliar o potencial mercadológico da área geográfica onde reside a maior parte dos futuros clientes do SC. 
De acordo com Portugal e Goldner (2003), umas das etapas elementares na avaliação dos impactos causados no sistema viário é o tratamento da área de influência do empreendimento, sendo esse estudo fundamental no processo que antecede a sua implantação. Isso permite analisar os possíveis focos de congestionamento, garantindo adequado planejamento do uso do solo e determinando as características socioeconômicas da população residente nos locais afetados pelo empreendimento, gerando assim uma análise de viabilidade econômica de implantação do futuro PGV.

A delimitação da área de influência normalmente é dividida em três categorias: área primária, secundária e terciária. Essa classificação reproduz o grau de atração de viagens, conseqüentemente, o grau de impacto que o empreendimento causa no sistema viário. Quesitos como: natureza e tamanho do empreendimento, acessibilidade, densidade e características socioeconômicas da população, barreiras físicas, limitações de tempo e distância de viagem, poder de atração e competição do futuro SC, distância ao centro da cidade e dos principais concorrentes, são utilizados para a delimitação da área de influência do empreendimento (Portugal e Goldner, 2003).

Em geral, as variáveis tempo de viagem e distância são os critérios mais utilizados para a definição do traçado das áreas de influência. A Tabela 2.3 relaciona parâmetros adotados em alguns trabalhos sobre o tema. 
Tabela 2.3: Área de influência e percentuais de viagens (modificado - Portugal e Goldner, 2003).

\begin{tabular}{|c|c|c|c|}
\hline Autores & Área Primária & Área Secundária & Área Terciária \\
\hline CET - SP (1983) & $\begin{array}{c}60 \% \text { das viagens estendem-se a uma distância de até } 5 \mathrm{~km} \text { do Shopping } \\
\text { Center, enquanto que } 80 \% \text { a uma distância de até } 8 \mathrm{~km} .\end{array}$ \\
\hline Grando (1986) & $\begin{array}{c}\text { Atrai } 45 \% \text { das viagens } \\
\text { de até } 10 \text { min }\end{array}$ & $\begin{array}{c}\text { Atrai } 40 \% \text { das viagens } \\
\text { de } 10 \text { a } 20 \text { min }\end{array}$ & $\begin{array}{c}\text { Atrai } 8,3 \% \text { das viagens } \\
\text { de } 20 \text { a } 30 \text { min }\end{array}$ \\
\hline Silveira (1991) & $\begin{array}{c}\text { Atrai } 37,7 \% \text { das } \\
\text { viagens de até } 10 \text { min }\end{array}$ & $\begin{array}{c}\text { Atrai } 24,5 \% \text { das } \\
\text { viagens de } 10 \text { a } 20 \text { min }\end{array}$ & $\begin{array}{c}\text { Atrai } 20,8 \% \text { das } \\
\text { viagens de } 20 \text { a } 30 \text { min }\end{array}$ \\
\hline
\end{tabular}

De acordo com o trabalho de Kneib (2004) os PGVs atribuem à sua área de influência características de centralidade, explicados pela sua implantação e operação, pois atraem atividades e alteram os padrões de uso e ocupação do solo no seu entorno, tal como as ZCNs. Por isso, podem causar alterações significativas nos padrões de uso, ocupação e valorização do solo em sua área de influência imediata.

Grigolon e Silva (2006), por outro lado, argumentam que o comportamento observado para o PGV não se daria de acordo com a teoria de centralidade, tal como para as ZCNs, e sim como conseqüência direta do mercado imobiliário. Os lotes mais próximos ao empreendimento ficariam retidos para posterior valorização, fazendo com que, à medida que se afastam do PGV, a "idade" dos imóveis comerciais cresça devido à influência de outros empreendimentos antes existentes nas vizinhanças e sobretudo como conseqüência de menores valores dos imóveis. A Figura 2.1 ilustra a diferença dos pontos de vista observado em Kneib (2004) e Grigolon e Silva (2006), respectivamente. 


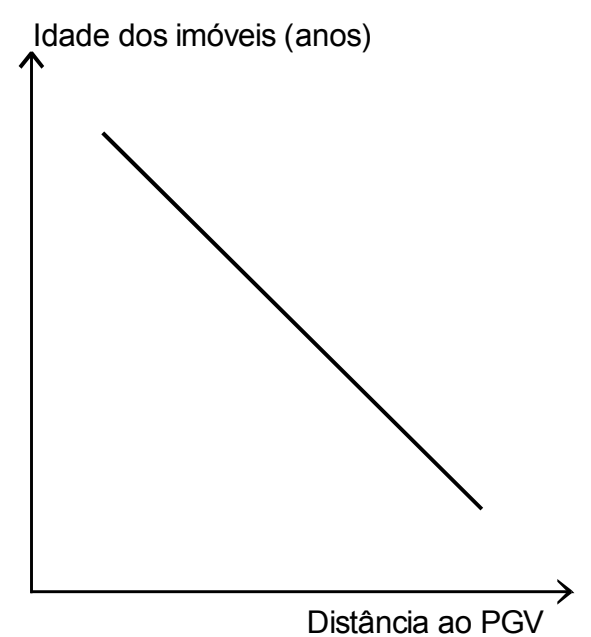

Teoria da Centralidade

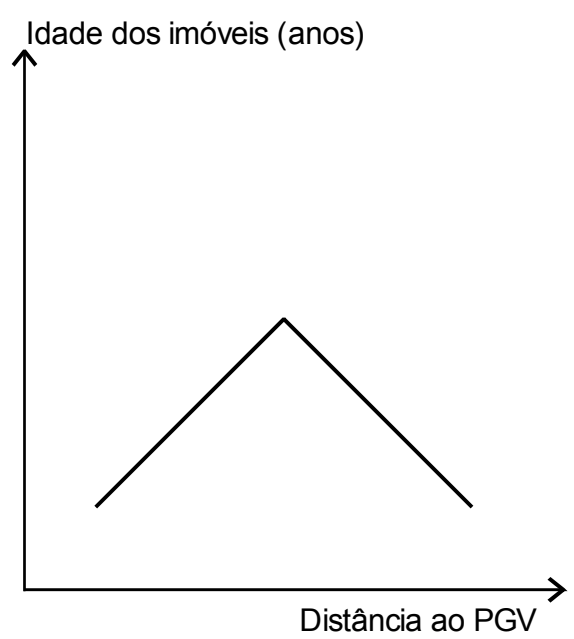

Hipótese de Grigolon e Silva (2006)

Figura 2.1: Teorias sobre os padrões de ocupação espacial dos PGVs

A escolha do local para implantação de um pólo gerador pode depender de alterações ou ampliações do sistema viário de entorno. Para a legislação do Município de Campinas, o processo de aprovação do projeto de construção ou da expedição de alvará de funcionamento do PGV somente poderá ser iniciado após a conclusão da análise da consulta sobre as condições necessárias de vagas, acessos e demais parâmetros e eventuais adequações no sistema viário e sua sinalização.

O trabalho de Cheng et al. (2005) mostra um processo de escolha do local para a implantação de um PGV usando Sistemas de Informações Geográficas (SIG). Na maioria das vezes, a escolha do local é feita pela simples análise em termos de cálculos rudimentares, experiências passadas ou mesmo por preferência. Além da localização e locação do futuro PGV, essa abordagem é adequada para outras estratégias de negócios, como penetração de mercado, previsão de negócios, influência no comportamento/perfil do consumidor etc. 
Embora o processo de escolha estratégica do local de implantação de um PGV seja importante tanto para projetos públicos quanto para privados, os grandes empreendedores comerciais escolhem o local para implantação do seu empreendimento em função das potenciais características de crescimento econômico da região. Muitas vezes, os locais escolhidos estão nas zonas periféricas justamente pelo fato do empreendedor estar interessado, além da área propriamente dita para a implantação do empreendimento, em adquirir as áreas circunvizinhas para reter sua ocupação para futura especulação imobiliária. No entanto, para tal é primordial que estas zonas periféricas sejam interligadas com o restante da cidade com uma estrutura viária mínima.

Já os pequenos empreendedores comerciais usam da infra-estrutura viária e dos grandes empreendimentos, que já atraem ou que futuramente irão atrair grande quantidade de viagens, para se instalarem nas imediações do PGV e ao longo das regiões próximas às vias existentes e usufruírem da alta demanda para a região.

Alguns trabalhos recentes e que apresentam relação com o tema por discutirem a relação de dependência espacial entre a infra-estrutura de transportes e o uso do solo são: Lemos, Santos e Portugal (2004; 2005; 2006), Silva e Vala (2001), Wedagama, Bird e Metcalfe (2005), Greenwald (2006), Casello (2006), Paez (2006), Carsjens e Ligtenberg (2006).

O presente trabalho visa apresentar uma contribuição para a continuidade das investigações sobre a inter-relação entre o uso do solo, mais especificamente daqueles associados a grandes PGVs, e a infra-estrutura de transportes, através de duas técnicas de análise espacial: a 
Estatística Espacial e a Modelagem Espacial. Alguns dos conceitos sobre esses temas são apresentados no próximo capítulo. 


\section{Análise espacial}

O objetivo deste capítulo é apresentar um referencial teórico sobre os principais conceitos relacionados à Análise Espacial, utilizados nesta pesquisa: a Estatística Espacial e a Modelagem Espacial.

\subsection{Introdução}

Segundo (Câmara et al., 2002a), a análise espacial é definida como o estudo, a exploração e modelagem de processos que se expressam através de uma distribuição no espaço. O propósito da análise espacial é mensurar propriedades e relacionamentos, levando em conta a localização espacial do fenômeno em estudo, característica fundamental para a sua análise. A análise espacial é composta por um conjunto de procedimentos encadeados cuja finalidade é a escolha de um modelo inferencial que considere explicitamente os relacionamentos espaciais presentes no fenômeno. Em geral, o processo de modelagem é precedido de uma fase de análise exploratória, associada à apresentação visual dos dados sob forma de gráficos e mapas e a identificação de padrões de dependência espacial. 
Existem, de acordo com Anselin (1992) e (Câmara et al., 2002b), três tipos de análise espacial:

- Análise de eventos ou padrões pontuais

- Análise de superfícies contínuas

- Análise de dados em áreas

A concentração dessa pesquisa é na análise de dados em área, utilizando duas vertentes da Análise Espacial: a Estatística Espacial e a Modelagem Espacial.

\subsubsection{Estatística Espacial}

Segundo Lopes (2005) o conjunto amplo de técnicas, que incluem métodos estatísticos e que procuram descrever a variação espacial do fenômeno em estudo, a partir de amostras disponíveis, é chamado de "Estatística Espacial". É um desdobramento da análise espacial, cujo objetivo é a quantificação da dependência espacial presente em um conjunto de dados.

A estatística espacial difere da estatística clássica pelo fato de considerar a localização espacial dos atributos. Dessa forma, um dos preceitos da estatística clássica, que é o da independência entre as variáveis, não se aplica à estatística espacial, uma vez que a localização espacial, a qual pode ser tratada como uma variável e ainda, dependente, constitui uma informação fundamental.

Quando são utilizadas técnicas de estatística espacial para análise de dados em áreas, estas são apresentadas em forma de índices que medem a associação espacial (Índice de Moran, por exemplo), gráfico de espalhamento (Box Map) e mapas (distribuição espacial). Estes índices 
auxiliam na identificação de agrupamentos de objetos cujos atributos possuem valores altos e baixos, áreas de transição e casos atípicos (Krempi, 2004).

Alguns exemplos da aplicação de estatística espacial em diversas áreas do conhecimento podem ser encontrados em: Kampel, Câmara e Quintanilha (2000); Kabos e Csillag (2002); Ramos e Silva (2003a; 2003b; 2007); Queiroz (2003); Teixeira (2003); Ramos, Silva e Miranda (2004); Krempi (2004); Silva (2004); Ping et al. (2004); Orford (2004); Premo (2004); Lopes (2005); Manzato, Soares e Silva (2006); Manzato e Silva (2006); Grigolon, Manzato e Silva (2007).

Parte do conjunto de técnicas que compõem a estatística espacial é tratado por Anselin (1995) como Análise Exploratória de Dados Espaciais, ESDA, do inglês: Exploratory Spatial Data Analysis, onde, além da necessidade da investigação dos valores extremos de uma determinada variável, é importante investigar o comportamento em relação à vizinhança.

Alguns conceitos sobre as técnicas de ESDA devem ser citados, pelo fato desta pesquisa ser aplicada com dados em áreas. O primeiro se refere à MATRIZ DE PROXIMIDADE ESPACIAL (W), também chamada de matriz de adjacência ou matriz de peso/ponderação espacial, é o elemento principal no estudo da dependência espacial de áreas. Com ela se estima a variabilidade espacial dos dados, descrevendo o arranjo espacial dos objetos.

A MÉdiA MÓVEL ESPACIAL $\left(\mathbf{W}_{\mathbf{Z}}\right)$, também conhecida como vetor de médias ponderadas ou média dos valores dos vizinhos, é utilizada para explorar a variação da tendência espacial dos dados, por meio da avaliação da média dos valores dos vizinhos.

Um dos INDICADORES DE AUTOCORRELAÇÃO ESPACIAL mais difundidos é o índice de Moran, que fornece uma medida geral da associação espacial existente no conjunto 
dos dados. Seu valor varia de -1 a 1 . Valores próximos de zero indicam a inexistência de autocorrelação espacial significativa entre os valores dos objetos e seus vizinhos. Valores positivos para o índice indicam autocorrelação espacial positiva, ou seja, o valor do atributo de um objeto tende a ser semelhante aos valores dos seus vizinhos. Valores negativos para o índice, por sua vez, indicam autocorrelação negativa (Neves et al., 2000). Pode ser calculado de acordo com a Equação 3.1.

$$
I=\frac{Z^{t} W_{z}}{Z^{t} Z}
$$

\section{Equação 3.1: Índice de Moran (global)}

O expoente t define vetor transposto, $\mathrm{Z}$ é um vetor de médias (desvios) e Wz é um vetor de médias ponderadas.

Embora seja capaz de apontar a tendência geral de agrupamento dos dados, o I de Moran é uma medida global e por isso não revela padrões locais de associação espacial, ou seja, a estrutura regional de autocorrelação espacial.

Uma maneira de visualizar a dependência espacial é através do diagrama de espalhamento de Moran, cujo gráfico é subdividido em quatro quadrantes que indicam pontos de associação espacial. Podem-se identificar quatro zonas distintas, normalmente definidas como quadrantes um (Q1), dois (Q2), três (Q3) e quatro (Q4).

- Q1: revela microrregiões com alto valor da variável sob análise, cercada de vizinhos que também possuem valores semelhantes (quadrante superior direito);

- Q2: revela microrregiões com baixo valor circundadas por outras de valores também baixos (quadrante inferior esquerdo); 
- Q3: aponta microrregiões de baixo valor que são vizinhas de outras com alto valor (quadrante superior esquerdo).

- Q4: aponta microrregiões de alto valor que possuem vizinhos com baixo valor (quadrante inferior direito);

Em Manzato (2007) encontra-se um exemplo de aplicação do diagrama de espalhamento de Moran (chamado de Box Map), juntamente com um mapa temático para visualizar os resultados, mostrados na Figura 3.3. Exemplos também podem ser vistos nos trabalhos de Yrigoyen (2005), Krempi (2004) e Lopes (2005), entre outros.
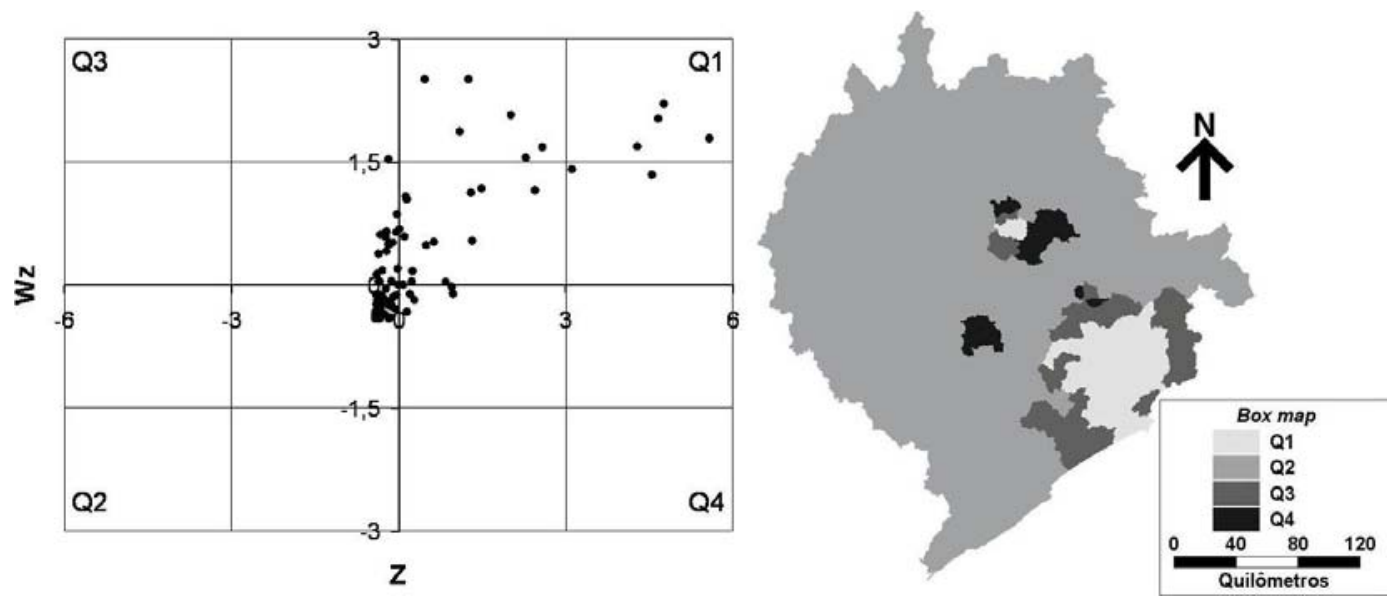

Figura 3.1: Gráfico e mapa de espalhamento de Moran

(Fonte: Manzato, 2007)

\subsubsection{Modelagem Espacial}

A modelagem espacial veio a complementar a análise espacial e os sistemas de informação geográficas por introduzir um caráter dinâmico aos fenômenos antes apenas analisados de forma estática. Para o planejamento de transportes, devido à alta complexidade de seus processos, os modelos dinâmicos foram muito úteis para gerar cenários múltiplos de decisão. Esse sucesso pode ser explicado pela possibilidade de se compreender dinâmicas entre elementos e através das simulações desenvolvidas (Silva, 2002). 
Recentemente têm-se observado o desenvolvimento da técnica de Autômatos Celulares, do inglês Cellular Automata (CA) para a simulação de diferentes cenários de desenvolvimento urbano, considerando-se as inúmeras variáveis das cidades. O conceito principal da utilização de CA é a possibilidade da extração de padrões regionais através do comportamento local de um reduzido número de elementos.

As técnicas CA realizam a avaliação das variáveis mais importantes para a evolução dos fenômenos em análise e, assim, criam-se mecanismos de previsão de tendências futuras. São sistemas dinâmicos nos quais o espaço e o tempo são discretos, com comportamento especificado em termos de uma relação local. O espaço é representado por uma grade uniforme composta de várias células, as quais podem assumir alguns estados predefinidos (Ramos e Silva, 2002).

Taylor (1992) afirma que os modelos CA procuram explicar alguns fenômenos através de regras simples, permitindo aos seus componentes a interação dinâmica até o fenômeno macroscópico emergir.

Anteriormente à utilização dos modelos é necessário tomar várias decisões para a construção de um CA específico, transformando o problema em estudo em um modelo de CA. Os mais importantes componentes a serem definidos são, de acordo com Ramos e Silva (2002) e White e Engelen (2000), Yang e Wang (2002):

- Uma rede ou um espaço regular;

- Estados que caracterizam as células;

- Definição da vizinhança de uma célula; 
- Regras de transição que determinam os estados de cada célula em função de suas vizinhanças;

- Uma seqüência de períodos temporais discretos, quando todas as células são atualizadas simultaneamente.

A vizinhança em que uma célula interage é a própria célula e o conjunto de células adjacentes. No caso de rede quadrada, dois tipos de vizinhança são comumente utilizados: von Neumann, na qual as células adjacentes a uma outra formam uma cruz centrada nesta; e a de Moore, na qual as células adjacentes formam um quadrado em torno da célula central. A vizinhança também pode ser arbitrária. Os três tipos de vizinhança são mostrados na Figura 3.2.
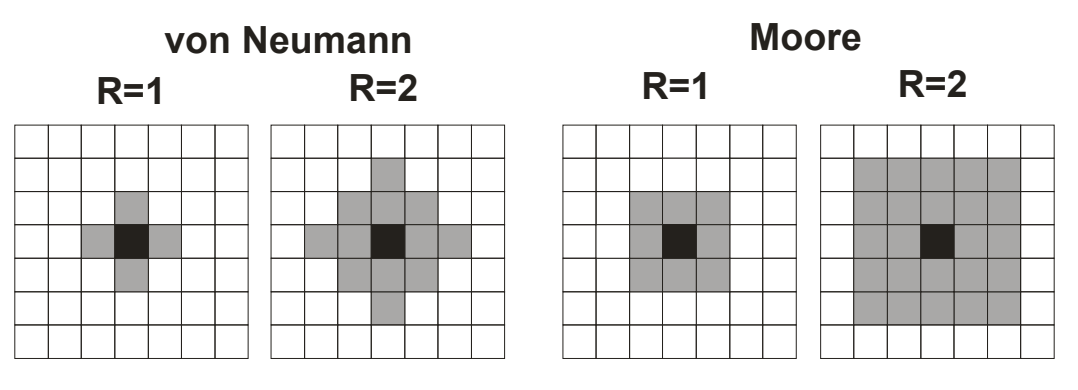

Arbitrária

Figura 3.2: Exemplos de diferentes tipos de vizinhanças (Fonte: Viher et al., 1998)

De acordo com Viher et al. (1998), a geometria da rede é baseada em sua dimensão e forma. Para facilitar a representação e visualização utiliza-se uma rede quadrada, na maioria dos casos. No entanto, sabe-se que os objetos das cidades não são regulares na maioria das vezes, portanto, a utilização das redes irregulares aumentaria o realismo dos modelos.

Os CA são normalmente implementados segundo critérios locais, isto é, as regras de transição são aplicadas na vizinhança de uma célula. No entanto, em muitos casos de processos urbanos, a função de transição deve levar em conta diferentes fatores, incluindo: os efeitos da 
vizinhança, o fator ambiental, as taxas demográficas da região, a demanda por uma determinada atividade econômica e o comportamento dos agentes econômicos (Pedrosa e Câmara, 2002).

Segundo Santos (2005), s regras de transição podem ser sintetizadas em três tipos:

- Determinística, que se destaca pela sua simplicidade e por permitir a reprodução das suas modelagens;

- Estocástica, onde são introduzidos fatores aleatórios com o objetivo de reproduzir aspectos não explicáveis pelos modelos;

- Obtidas por Redes Neurais Artificiais (RNA), onde os valores dos parâmetros são determinados automaticamente a partir de treinamento da rede neural com os dados, o que, por um lado, facilita a simulação, e por outro, não permite que se conheçam as regras de transição adotadas.

A última abordagem vem sendo muito utilizada quando comparada aos modelos estatísticos convencionais pelo fato das RNA apresentarem alto desempenho no tratamento dos dados e por serem robustas e tolerantes a erros. Portanto, para o presente trabalho, as regras de transição foram obtidas através das REDES NEURAIS ARTIFICIAS (RNA). A Figura 3.3 ilustra uma estrutura básica de uma RNA.

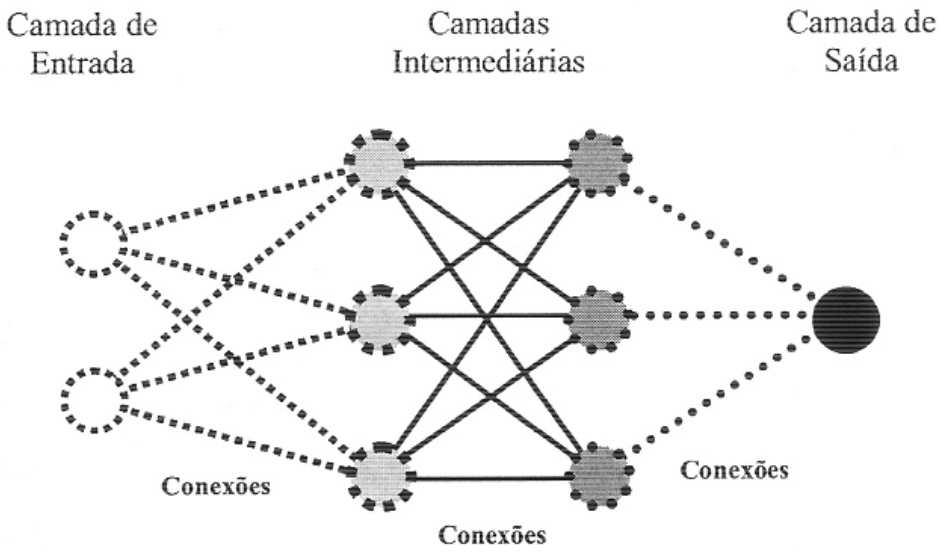

Figura 3.3: Estrutura básica de uma RNA

(Fonte: Silva et al., 2004) 
As RNA possuem também alguns componentes principais, a saber: conjunto de elementos de processamento, estado de ativação, função de saída para cada elemento de processamento, ligações entre elementos de processamento, propagação e função de combinação, ativação, aprendizagem e ambiente onde o sistema opera. A seguir são apresentados alguns detalhes desses componentes:

- Elementos de processamento: são os principais elementos de uma RNA e estão relacionados à sua topologia, ou seja, a especificação do número de neurônios que constituirá a rede, bem como a sua organização nas camadas;

- Estado de ativação: cada neurônio em uma RNA tem um estado de ativação associado, o qual depende do que se procura representar com o modelo. Em geral, o estado de ativação pode ser representado por uma função contínua ou discreta;

- Função de saída de cada elemento de processamento: os neurônios produzem um sinal de saída que está relacionado com a sua ativação por meio de uma função de transferência (função de saída). Esta função tem o objetivo de controlar a intensidade da função de ativação para se obter o desempenho desejado na rede;

- Ligações entre elementos de processamento: as ligações entre os neurônios são representadas por uma matriz de pesos e definem o conhecimento do sistema. Pesos positivos são ligações que excitam, gerando um reforço na ativação, e pesos negativos inibem a ativação do neurônio. 
- Propagação da função de combinação: são regras com as quais os valores de entrada de um neurônio são combinados com os valores da respectiva matriz de pesos para produzir a entrada líquida;

- Aprendizagem: processo em que a rede extrai informações relevantes dos exemplos a ela apresentados, criando uma representação própria para o problema.

Os Modelos de RNA se diferenciam dos modelos tradicionais de previsão por serem modelos não-paramétricos, envolvendo algoritmos de aprendizado. Tais algoritmos buscam imitar as interconexões do cérebro humano, com o intuito de incorporar o padrão de comportamento de uma série temporal de modo a prever, da maneira mais eficiente possível, valores futuros dessa série.

A obtenção de boas previsões com uma RNA depende: (i) do tipo de dados, (ii) da técnica do analista na escolha do modelo apropriado, e (iii) dos métodos numéricos usados para ajustar o modelo e calcular as previsões. Um bom ajuste da rede não é garantia de previsões acuradas, fato explicado pela incerteza quanto à arquitetura ideal da rede, dada a inexistência de um critério universalmente aceito de escolha da mesma. Tal problema reflete na incerteza quanto à determinação do tamanho da rede, em termos do número de entradas e do tamanho da camada oculta (Faraway e Chatfiled 1995).

Após os comentários sobre alguns conceitos básicos envolvendo a análise espacial e duas de suas vertentes (Estatística e Modelagem espacial), é apresentado no próximo capítulo o método proposto no estudo de caso aqui desenvolvido. 
Este capítulo descreve o método adotado para o estudo do impacto da localização de Pólos Geradores de Viagens (PGVs), discutindo-se primeiramente os principais aspectos relacionados à Estatística espacial e à Modelagem espacial referentes à aplicação no presente trabalho. Em seguida, esses aspectos são detalhados em um estudo de caso para o município de Campinas - SP, apresentando a origem dos dados utilizados, bem como o seu tratamento e formatação. Nesse capítulo também estão inseridas algumas características do município referentes aos seus aspectos político-administrativos e econômicos e também dos PGVs analisados.

\subsection{Técnicas empregadas}

Inseridos na Estatística espacial, os conceitos de Análise Exploratória de Dados Espaciais (ESDA, do inglês Exploratory Spatial Data Analysis), são utilizados para caracterizar regiões na área de estudo que apresentam comportamentos similares em termos de algumas variáveis. Essas técnicas de ESDA agrupam algumas ferramentas como índices, gráficos e mapas. O índice de Moran, em conjunto com os gráficos e mapas de Moran, são os mais utilizados, encontrados com 
freqüência na literatura em diversas aplicações (como, por exemplo, em Ramos e Silva, 2003a, 2003b e 2007; Ramos et al., 2004; Manzato et al., 2006 e Manzato e Silva, 2006).

Em particular no que se refere ao gráfico e mapa de Moran, os resultados podem ser classificados segundo quadrantes, normalmente definidos como quadrantes Q1, Q2, Q3 e Q4, conforme detalhado no capítulo 3.

Os três elementos principais para a utilização da análise exploratória de dados espaciais, a matriz de proximidade espacial ( $W$ ), o vetor de desvios $(Z)$ e o vetor de médias ponderadas $\left(W_{Z}\right)$, podem ser obtidos de diversas maneiras. O software SPRING foi utilizado, por exemplo, por Lopes (2005). Outra maneira é por meio do software TransCAD, como sugerido por Manzato (2007). Outras formas possíveis são o software ArcView, com a extensão Spacestat (Anselin e Bao, 1997; Anselin e Smirnov, 1998) incorporada ao programa, ou o pacote GeoDa (Anselin, 2003).

A justificativa de se utilizar esta técnica nesta pesquisa se deve ao fato de que a representação em mapas temáticos simplesmente por meio do valor numérico obtido torna difícil a comparação direta entre as diversas variáveis envolvidas. Desta forma, obtém-se uma padronização dos resultados por meio de um método que permite informar se existe ou não semelhança entre as variáveis ao considerar relações de vizinhança entre as entidades espaciais.

A Modelagem espacial, que é outra vertente da Análise espacial, foi também utilizada nesta pesquisa, se integrando à etapa da análise confirmatória de dados espaciais e que também se utiliza de ferramentas da Estatística espacial. O modelo proposto neste estudo utiliza, por exemplo, os dados relativos ao gráfico de Moran para identificar a importância relativa dos quadrantes a que pertencem os vizinhos ao estabelecer as regras de transição. Este processo é semelhante ao adotado nos Cellular Automatas (CAs) em dois aspectos: na adoção de regras de 
transição (que neste estudo foram obtidas, de acordo com a sugestão do trabalho de Ramos e Silva (2007), por meio de redes neurais) e pela hipótese básica de que relações locais geram padrões globais.

Após o conhecimento dos aspectos fundamentais que fazem parte das etapas metodológicas do presente estudo, é apresentado na seqüência um detalhamento das atividades para um estudo de caso desenvolvido para o município de Campinas, estado de São Paulo.

\subsection{Estudo de caso}

O município de Campinas possui 232 anos de emancipação política (14 de julho de 1774). Com uma área de $796 \mathrm{~km}^{2}$, Campinas é uma cidade espraiada, onde $53 \%$ do território corresponde à área rural, muito embora se trate mais exatamente de um "rural de expansão urbana", marcado fortemente pela atividade comercial, de prestação de serviços de alto valor agregado, e particularmente por configurar-se como espaço de moradia das camadas de alta renda.

A cidade propriamente "urbana" é uma cidade adensada (construtiva e demograficamente), caracterizada como espaço de circulação e mobilidade (inclusive da população da região metropolitana), vivência coletiva e sociabilidades. Maior cidade interiorana do país, Campinas contava em 2003 com aproximadamente um milhão de habitantes, contingente esse formado sobretudo entre os anos 70 e 80 , quando cerca de $2 / 3$ da população da cidade era constituída de pessoas não nascidas no município. O Índice de Desenvolvimento Humano médio é igual a 0,852 , classificado como alto em uma escala de valor máximo igual a 1 (Prefeitura Municipal de Campinas, 2006). 
No estudo de caso, foram analisadas três regiões da cidade: a Zona Central de Negócios (ZCN) de Campinas, com o ponto central situado na Prefeitura Municipal, indicando o centro histórico da cidade; e dois PGVs: o Shopping Iguatemi Campinas e o Shopping Galleria. O Shopping Iguatemi Campinas foi inaugurado em maio de 1980 e possui um total de 281 lojas, divididas entre âncoras, satélites, praça de alimentação e áreas de lazer. Pelo seu fácil acesso e pela variedade de lojas e serviços que oferece, o Shopping Center Iguatemi Campinas costuma receber uma média anual de visitantes estimada em 22 milhões. O Shopping Galleria foi inaugurado em outubro de 1992, conta com 145 lojas e, segundo consta em seu site na internet, possui uma área de influência de 510.580 habitantes, com um fluxo médio de mais de 5 milhões de visitas por ano.

Na Tabela 4.1 estão organizadas informações específicas dos dois empreendimentos.

Tabela 4.1: Informações específicas sobre os shoppings em estudo.

\begin{tabular}{|c|c|c|}
\hline & $\begin{array}{c}\text { SHOPPING CENTER } \\
\text { IGUATEMI CAMPINAS }\end{array}$ & GALLERIA SHOPPING \\
\hline Data de Inauguração & MAIO, 1980 & OUTUBRO, 1992 \\
\hline $\begin{array}{c}\text { Data de Filiação à } \\
\text { ABRASCE }\end{array}$ & $01 / 12 / 1978$ & $31 / 08 / 1998$ \\
\hline Área Bruta Locável & $58000 \mathrm{~m}^{2}$ & $19782 \mathrm{~m}^{2}$ \\
\hline Área Construída & $140000 \mathrm{~m}^{2}$ & $38920 \mathrm{~m}^{2}$ \\
\hline Área Total Terreno & $130000 \mathrm{~m}^{2}$ & $78125 \mathrm{~m}^{2}$ \\
\hline Lojas Âncora & 11 & $\mathrm{NA}$ TEM \\
\hline Lojas Satélite & 225 & 03 \\
\hline Pisos & 03 & 08 \\
\hline Escadas Rolantes & 06 & 02 \\
\hline Elevadores & 02 & 06 \\
\hline Vagas de Carro & 5305 & 1882 \\
\hline Cinemas & 08 & 06 \\
\hline
\end{tabular}

Após a descrição de algumas características principais da cidade e dos PGVs estudados no presente trabalho, a metodologia aqui desenvolvida envolve as três etapas aqui listadas, seguidas de suas respectivas explicações: i) Aquisição e tratamento dos dados; ii) Análise Exploratória de Dados Espaciais, através da Estatística espacial e; iii) Construção do modelo usando conceitos de Cellular Automata (CA) com a ferramenta de Redes Neurais Artificiais. 


\subsubsection{Aquisição e tratamento dos dados}

Para este estudo de caso, os dados utilizados para a primeira parte da análise foram obtidos junto à Prefeitura Municipal de Campinas. As informações, que foram disponibilizadas em base geográfica compatível com Sistemas de Informações Geográficas (SIG), são de uso de solo urbano por período, para uma grande parcela dos lotes urbanos, totalizando 170.497 registros, o que representa $47 \%$ da cidade.

Os dados originais estão representados por uma base geográfica de pontos, e contém informações sobre lotes residenciais, comerciais e industriais. O tipo de uso considerado para esse estudo foi o comercial, já que se pretende avaliar o impacto do surgimento de novos PGVs mediante a localização e porte de outros PGVs existentes, aqui tratados como lotes comerciais. Para a utilização dos conceitos de ESDA mencionados anteriormente, os dados (inicialmente em uma base de pontos) foram agregados em uma base de áreas, representando células regulares de 100 x 100 m. Após essa alteração, a nova base de dados (agora representada por áreas e não mais por pontos) ficou reduzida a 4858 registros. A Figura 4.1 mostra, à esquerda, a base de pontos sobreposta pela base de áreas representada pelas células e, à direita, um mapa temático representando uma contagem do número de pontos em cada célula. 

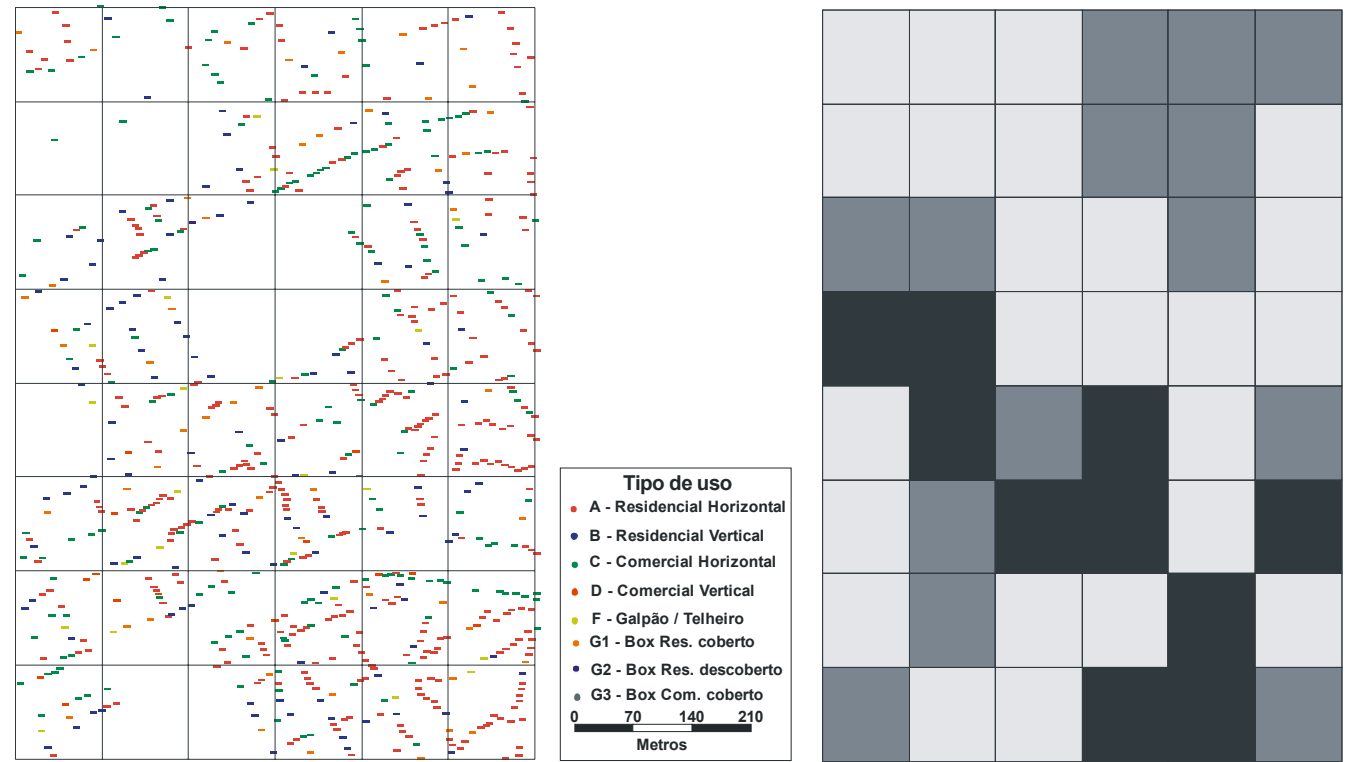

Pontos nas células 0 a 199

200 a 399 400 a 1000

Figura 4.1: Base de áreas representando os dados de ocupação do solo

Com a base de dados organizada e sabendo-se que o foco do trabalho aqui estudado está relacionado ao uso e ocupação do tipo comercial, duas variáveis principais são analisadas:

- Número absoluto de unidades comerciais, por período. Compreende a contagem apenas dos registros comerciais, excluindo-se todos os outros usos. Esse número será armazenado na célula de acordo com o exemplo mostrado na Figura 4.1;

- Proporção de uso comercial, por período. Variável obtida através da divisão do número absoluto de unidades comerciais pelo total de registros, para cada um dos períodos analisados. Esse número também estará contido nas informações das células, de acordo com a Figura 4.1.

Os períodos considerados são apresentados em cinco classes, a saber: i) até 1979; ii) de 1980 a 1985; iii) de 1986 a 1991; iv) de 1992 a 1997 e v) de 1998 a 2003. É importante salientar que os períodos foram separados de 6 em 6 anos para que em cada classe houvesse aproximadamente o mesmo número de registros. O período "até 1979", no entanto, possui registros que vão de 1920 até 1979. 
Para a segunda parte da análise foi necessária a aquisição de dados que representassem a infra-estrutura viária de Campinas, já que os Pólos Geradores de Viagens, além dos impactos que causam na circulação de tráfego e no entorno, geralmente com repercussão em toda a região (Grando, 1986), têm também sua localização fortemente influenciada pela infra-estrutura de transportes. Para isso, obteve-se, através do programa Google Earth, a imagem da malha viária principal de Campinas (Figura 4.2) e o processo de georreferenciamento foi feito manualmente pelo software TransCAD, da seguinte forma:

- Seleção de três pontos não alinhados para a marcação de suas coordenadas. Na Figura 4.2 estão assinaladas áreas em vermelho ilustrando as regiões onde os pontos estão situados. É recomendável que os três pontos formem uma área que abranja a área que se irá georreferenciar.

- Salvar a imagem do programa Google Earth com a extensão .TIF.

- No TransCAD, carregar a imagem TIF fornecendo as três coordenadas anotadas anteriormente. Dessa forma, a imagem estará conectada ao TransCAD, porém, nessa etapa, somente os três pontos serão conhecidos.

- Para que as vias sejam então georreferenciadas no TransCAD deve-se proceder à criação de um banco de dados de LINHAS.

- Desenhar a nova base de linhas a partir da imagem .TIF que servirá como guia para a criação da nova base contendo as principais vias de Campinas.

- Com o banco de dados de linhas contendo as vias principais de Campinas foi possível obter as duas variáveis de infra-estrutura de transportes: distância de cada célula à via (principal) mais próxima e densidade do sistema viário (principal) próximo a cada célula. Essas variáveis são apenas para o período de 
atual (2006), pelo fato de serem obtidas através de uma imagem que ilustra

a situação atual.

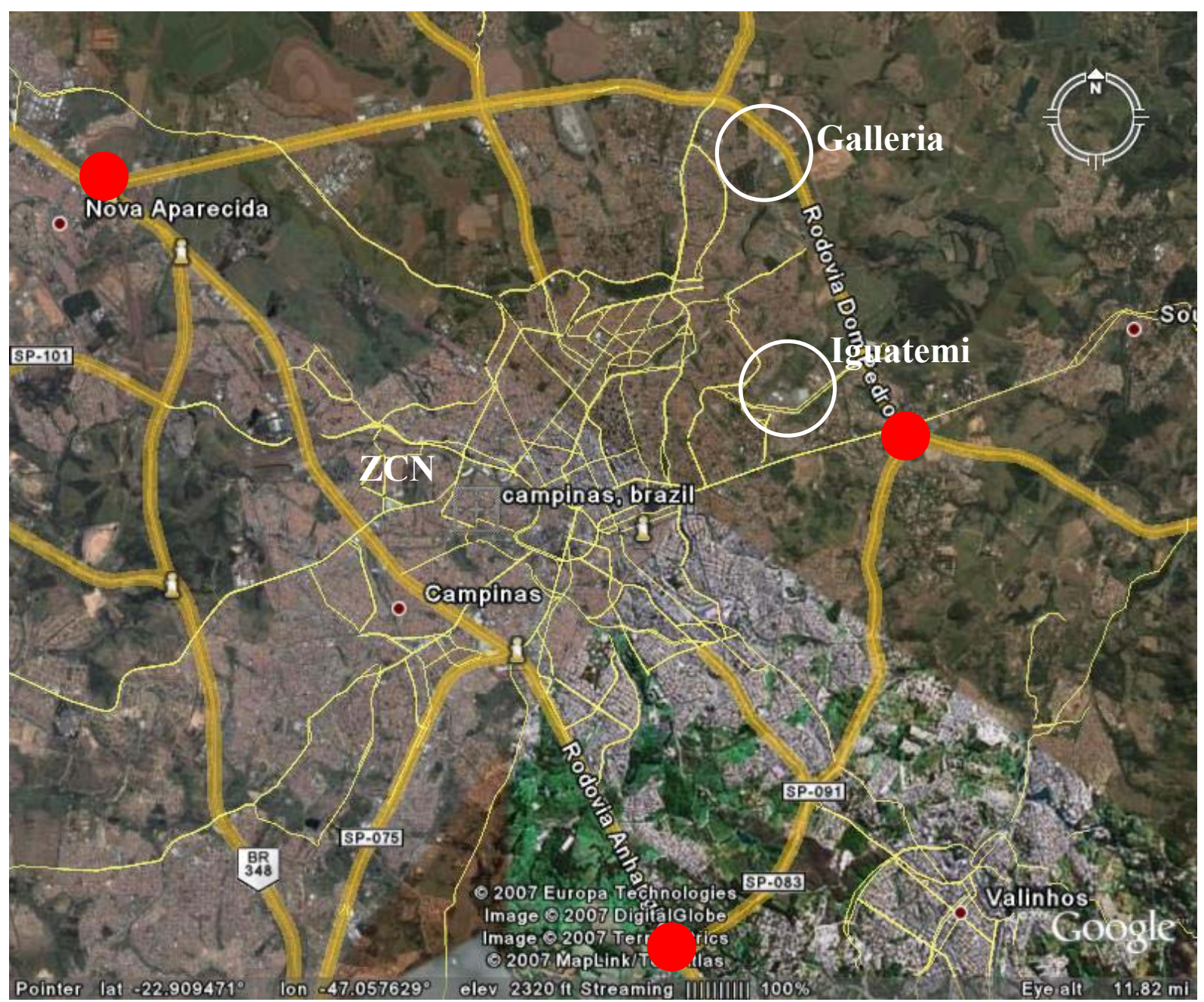

Figura 4.2: Imagem da malha viária principal de Campinas

Finalizada essa etapa de obtenção, tratamento e formatação dos dados procedeu-se à

Análise Exploratória dos Dados Espaciais sobre as variáveis de uso do solo, conforme se apresenta no próximo item.

\subsubsection{Análise Exploratória dos Dados Espaciais}

Esta segunda etapa da metodologia envolve uma Análise Exploratória dos Dados Espaciais, cujos fundamentos teóricos foram vistos anteriormente. Para esta análise, 
consideraram-se como mais relevantes apenas os dados de proporção de uso comercial. Uma análise preliminar considerando a variável número absoluto de unidades comerciais não se mostrou tão representativa em relação ao fenômeno estudado como a variável proporção de uso comercial, motivo pela qual apenas esta última mereceu uma análise mais detalhada.

O objetivo desta etapa é a verificação da influência do porte e localização de PGVs existentes na atração de novos PGVs, por meio da análise de uma variável relacionada à ocupação comercial (proporção de uso comercial).

As análises foram conduzidas por meio de ferramentas disponíveis no SIG ArcView, versão 3.2, utilizando-se também a extensão Spacestat (Anselin e Bao, 1997; Anselin e Smirnov, 1998) para o cálculo da matriz de proximidade espacial (W), além de uma planilha eletrônica. A matriz de proximidade espacial pode ser gerada por meio de duas alternativas relacionadas à condição de vizinhança: Rook ou Queen. No presente estudo, na geração da matriz de vizinhança, considerou-se os valores produzidos pela opção Queen, a qual considera os cantos das células como vizinhos, além da fronteira comum entre os lados das mesmas, como ilustra a Figura 4.3. As informações dessa matriz, utilizada em conjunto com uma planilha eletrônica previamente programada, calculam os outros elementos, $Z$ e $W_{Z}$, necessários para a análise.

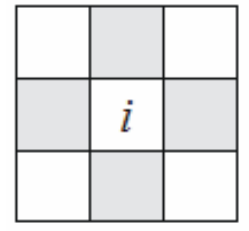

Rook

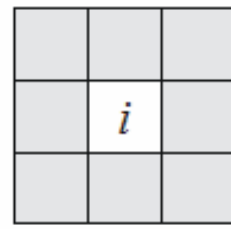

Queen

Figura 4.3: Condição de vizinhança Rook ou Queen

A partir dos resultados obtidos pelo indicador de ocupação comercial (proporção de uso comercial) e, de acordo com os conceitos de ESDA discutidos no capítulo 3, foram gerados mapas 
temáticos, classificados segundo os quadrantes do gráfico de Moran. Esses quadrantes representam a ocorrência das variáveis sobre o território, conforme pode ser constatado no Capítulo 5.

A aplicação da técnica de ESDA foi feita apenas sobre as variáveis de ocupação comercial, já que não eram conhecidos detalhes de variação da oferta de transportes ao longo do tempo que permitissem tal abordagem nesse caso. Seguindo o que sugere Manzato (2007), uma forma de se combinar diferentes indicadores pode ser por meio de modelos espaciais, alternativa que foi analisada no presente estudo e é detalhada no próximo item.

\subsubsection{Modelos espaciais}

Esta subseção trata da etapa referente à construção de um modelo de previsão utilizando conceitos de CA e, ainda, envolve a calibração, validação e aplicação do modelo propriamente dito para um período subseqüente.

Nesse sentido o modelo de previsão é baseado nas transições observadas nos períodos considerados (mencionados no item 4.2.1). Essas transições ao longo do tempo podem ser consideradas como mudanças de quadrantes do gráfico de Moran ao qual pertenciam os municípios. Motivados por algumas limitações de uma forma de modelagem que considerava regras de transição fixas (Ramos e Silva, 2003a e 2003b), Ramos e Silva (2007) apresentaram uma proposta que utiliza redes neurais artificiais para a modelagem das regras de transição. Demonstraram assim que o modelo sofreu sensíveis diferenças, apresentando algumas vantagens como: a possibilidade de se utilizar valores da variável analisada como valores de saída do modelo ao invés dos quadrantes e a possibilidade de se ter partes do conjunto de dados para validação e teste do modelo. 
No presente estudo, foi utilizado somente um tipo de modelo, testado com dois tipos de variáveis de entrada. O modelo é do tipo "3 IN 1 OUT", e foi construído com os 4858 registros referentes às variáveis de ocupação comercial, em que os valores de entrada do modelo eram variáveis de três períodos subseqüentes (por exemplo: até 1979, de 1980 a 1985, e de 1986 a 1991) e os valores de saída, referentes a um período (por exemplo, de 1992 a 1997). A Figura 4.4 ilustra um esquema desse tipo de modelo.

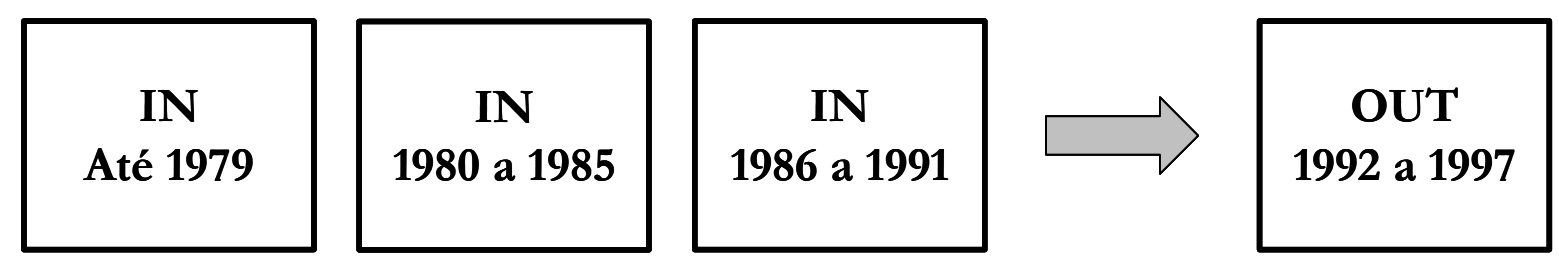

\section{MODELO “3 IN 1 OUT"}

Figura 4.4: Esquema ilustrativo do tipo de modelo desenvolvido

Embora a idéia inicial seja analisar a oferta de transportes em conjunto com a ocupação do solo, procurou-se avaliar o desempenho do modelo espacial utilizando-se duas combinações de variáveis. Quanto às variáveis utilizadas, o modelo foi subdividido em dois grupos, conforme é detalhado a seguir e sintetizado na Tabela 4.1.

- Modelo I: desenvolvido apenas com informações sobre a OCUPAÇÃO COMERCIAL. Estes modelos possuem as seguintes variáveis para cada célula: proporção de uso comercial, número absoluto de unidades comerciais, quadrante do gráfico de Moran ao qual pertencem, proporşão média de ocupação comercial dos vizinhos de cada célula e número de células vizinhas pertencentes a cada um dos quadrantes Q1, Q2, Q3 e Q4. 
- Modelo II: desenvolvido com informações sobre a OCUPAÇÃO COMERCIAL e com dados sobre a INFRA-ESTRUTURA DE TRANSPORTES incorporados, ainda que de forma parcial, posto que se referem somente a um período. Estes modelos possuem as mesmas variáveis do grupo anterior e a oferta de transportes é adicionada por meio das variáveis distância de cada célula à via (principal) mais próxima e densidade do sistema viário (principal) próximo a cada célula.

Tabela 4.2: Modelos espaciais desenvolvidos

\begin{tabular}{|c|c|}
\hline MODELO & VARIÁVEL \\
\hline (I) & Ocupação comercial \\
\hline (II) & Ocupação comercial \\
& + \\
& Infra-estrutura de Transportes \\
\hline
\end{tabular}

É importante salientar que as variáveis de ocupação comercial foram combinadas, para fins da modelagem, segundo códigos alfanuméricos que representam as classes de valores. Para a variável número absoluto de unidades comerciais foram adotadas as letras de "A" a "E" com os valores distribuídos igualmente entre as classes, variando do menor para o maior valor. Para a variável proporção de uso comercial foram adotados números de "1" a "5", também com valores crescentes distribuídos igualmente.

Portanto, o modelo desenvolvido neste trabalho utiliza a ferramenta de redes neurais para a modelagem do comportamento das transições observadas em cada célula, durante o período de 1920 a 2006. Com os dados dos períodos até 1979, de 1980 a 1985 e de 1986 a 1991 configurados como "entrada" e os do período de 1992 a 1997 configurados como "saída", foram selecionados aleatoriamente $25 \%$ dos dados para teste, $25 \%$ para validação e os $50 \%$ restantes foram 
utilizados para o treinamento da rede. Esta é a fase de calibração do modelo. A rede neural utilizada foi do tipo Multilayer Perceptron (MLP) com algoritmo de back propagation (Rumelhart et al., 1986).

Após essa etapa, a validação do modelo foi feita aplicando os dados dos períodos subseqüentes, a saber: de 1980 a 1985, de 1986 a 1991 e de 1992 a 1997 configurados como "entrada" e de 1998 a 2003 configurados como "saída". Finalmente, uma estimativa para um período de projeção futuro foi feito da mesma forma, aplicando-se os dados de 1986 a 1991, de 1992 a 1997 e de 1998 a 2003 configurados como "entrada" e, como "saída" do modelo, os resultados previstos para o período de 2004 a 2009. A Tabela 4.2 apresenta cada uma dessas fases juntamente com as variáveis envolvidas em cada modelo aqui desenvolvido.

Tabela 4.3: Variáveis utilizadas em cada modelo e em cada fase da modelagem por redes neurais

\begin{tabular}{|c|c|c|c|c|c|c|}
\hline \multirow{2}{*}{ MODELO } & \multicolumn{2}{|c|}{ FASE DE CALIBRAÇÃO } & \multicolumn{2}{|c|}{ FASE DE VALIDAÇÃO } & \multicolumn{2}{|c|}{ FASE DE PREVISÃO } \\
\hline & ENTRADA & SAÍDA & ENTRADA & SAÍDA & ENTRADA & SAÍDA \\
\hline I & $\begin{array}{c}\text { Variáveis de } \\
\text { ocupação comecial } \\
\text { nos períodos até } \\
\text { 1979, } 1980 \text { a } 1985, \\
1986 \text { a } 1991\end{array}$ & $\begin{array}{l}\text { Ocupação } \\
\text { comercial no } \\
\text { período de } \\
1992 \text { a } 1997\end{array}$ & $\begin{array}{c}\text { Variáveis de } \\
\text { ocupação comecial } \\
\text { nos períodos } 1980 \text { a } \\
\text { 1985, } 1986 \text { a } 1991 \text { e } \\
1992 \text { a } 1997\end{array}$ & $\begin{array}{l}\text { Ocupação } \\
\text { comercial no } \\
\text { período de } \\
1998 \text { a } 2003\end{array}$ & \begin{tabular}{|c|} 
Variáveis de \\
ocupação comecial \\
nos períodos 1986 a \\
1991 e 1992 a 1997 e \\
1998 a 2003
\end{tabular} & $\begin{array}{l}\text { Ocupação } \\
\text { comercial no } \\
\text { período de } \\
2004 \text { a } 2009\end{array}$ \\
\hline II & $\begin{array}{c}\text { Variáveis de } \\
\text { ocupação comecial } \\
\text { nos períodos até } \\
1979,1980 \text { a } 1985, \\
1986 \text { a } 1991 \text { e } \\
\text { variáveis de infra- } \\
\text { estrutura de } \\
\text { transportes }\end{array}$ & $\begin{array}{l}\text { Ocupação } \\
\text { comercial no } \\
\text { período de } \\
1992 \text { a } 1997\end{array}$ & $\begin{array}{c}\text { Variáveis de } \\
\text { ocupação comecial } \\
\text { nos períodos } 1980 \text { a } \\
\text { 1985, } 1986 \text { a } 1991 \text { e } \\
1992 \text { a } 1997 \text { e } \\
\text { variáveis de infra- } \\
\text { estrutura de } \\
\text { transportes }\end{array}$ & $\begin{array}{l}\text { Ocupação } \\
\text { comercial no } \\
\text { período de } \\
1998 \text { a } 2003\end{array}$ & \begin{tabular}{|c|} 
Variáveis de \\
ocupação comecial \\
nos períodos 1986 a \\
1991 e 1992 a 1997 e \\
1998 a 2003 e \\
variáveis de infra- \\
estrutura de \\
transportes
\end{tabular} & $\begin{array}{c}\text { Ocupação } \\
\text { comercial no } \\
\text { período de } \\
2004 \text { a } 2009\end{array}$ \\
\hline
\end{tabular}

Com esses modelos foram estimados os valores de ocupação comercial para o período 1998-2003, os quais foram representados por meio de mapas temáticos classificados segundo os quadrantes do gráfico de Moran e comparados com os dados reais. Além disso, o desempenho de cada modelo foi medido por meio do cálculo do número de acertos em cada quadrante e o seu acerto total. Finalmente, a partir dos modelos obtidos foi feita uma extrapolação para o período 2004-2009, verificando-se a ocupação comercial neste período. Os resultados desta etapa 
e de outras discutidas anteriormente podem ser observados no Capítulo 5. Adicionalmente, é apresentada no próximo item uma síntese das atividades desenvolvidas no presente estudo.

\subsection{Síntese das atividades desenvolvidas}

Com o intuito de facilitar o entendimento das etapas do presente estudo e possibilitar a reprodução do mesmo em trabalhos futuros, foi elaborada uma síntese das atividades desenvolvidas.

Nas etapas de obtenção, tratamento e formatação dos dados e análise exploratória dos dados espaciais, os seguintes passos foram desenvolvidos:

1. Aquisição de dados de uso e ocupação do solo contendo informações sobre (i) número absoluto de unidades comerciais, em períodos distintos e (ii) proporção de uso comercial, nos mesmos períodos considerados anteriormente, sendo essas informações disponibilizadas em base geográfica compatível com Sistemas de Informações Geográficas (SIG);

2. Ajuste da base de pontos, contendo as informações das variáveis citadas anteriormente, para uma base agregada de áreas, representada por células regulares de 100 x 100 m;

3. Determinação dos elementos $W, Z$ e $W_{Z}$, referentes à análise exploratória dos dados espaciais, para a variável proporção de uso comercial;

4. Determinação dos quadrantes a que pertence cada uma das células, para a variável proporção de uso comercial. Representação desses quadrantes em forma de mapas temáticos, classificados segundo os quadrantes Q1, Q2, Q3 e Q4. 
Com relação aos modelos espaciais, os passos necessários são:

1. Além da utilização das variáveis citadas anteriormente e do quadrante a que pertence cada célula (os quais já foram determinados), é necessário o cálculo das seguintes variáveis adicionais: proporção média de ocupação comercial dos vizinhos de cada célula e número de células vizinhas pertencentes a cada um dos quadrantes Q1, Q2, Q3 e Q4;

2. Construção dos modelos espaciais, de acordo com as informações das Tabelas 4.1 e 4.2;

3. Para a fase de treinamento da rede, seleção aleatória das proporções de registros para validação, teste e treinamento. O tempo destinado a esta fase depende do desempenho da rede, o qual é fornecido pelo próprio software, por meio do erro médio;

4. Para a fase de validação, construção de mapas temáticos com os resultados gerados pela rede. Comparar a porcentagem de acertos e erros, totais e parciais, dos quadrantes obtidos pelo modelo com os dados reais;

5. Para a fase de previsão, construção de mapas temáticos com os resultados gerados pela rede.

6. Repetir o procedimento de modelagem adicionando-se variáveis de infra-estrutura de transportes. Para isso, é necessária a aquisição de uma malha viária georreferenciada. Através dessa etapa é possível calcular valores das duas variáveis de infra-estrutura, consideradas nesta pesquisa: distância de cada célula à via (principal) mais próxima e densidade do sistema viário (principal) próximo a cada célula.

7. Criação de bandas ao redor dos PGVs em estudo e da ZCN, com extensão que represente significativamente a região da vizinhança que se deseja analisar.

8. Análise detalhada dos resultados do modelo para os PGVs e para a ZCN na fase de validação, através da comparação das classes de valores contendo as variáveis da situação real com a estimada pelo modelo. 
9. Análise detalhada dos resultados do modelo para os PGVs e para a ZCN na fase de previsão, através da comparação das classes de valores contendo as variáveis da situação real com a prevista pelo modelo.

10. Se for considerado para o estudo mais de um modelo com diferentes variáveis de entrada, proceder à avaliação comparativa dos resultados dos modelos desenvolvidos. 


\section{Análise dos resultados}

O capítulo em questão apresenta a descrição das análises dos resultados obtidos no estudo de caso do presente trabalho. Inicialmente são apresentados os resultados da Análise Exploratória de Dados Espaciais (ESDA), aplicada sobre a variável de ocupação comercial proporção de uso comercial, bem como comentários sobre as outras variáveis consideradas. A seguir são apresentados os resultados dos modelos espaciais desenvolvidos para o período 1998-2003, seguido da discussão do desempenho dos mesmos. Na seqüência são apresentados os resultados de projeções realizadas com os modelos para o período 2004-2009, e, por fim, uma avaliação comparativa dos resultados obtidos com os dois modelos.

\subsection{Análise exploratória dos dados de ocupação comercial}

As Figuras 5.1, 5.2, 5.3, 5.4 e 5.5 ilustram os resultados obtidos por meio da análise exploratória dos dados de proporção de uso comercial nos períodos até 1979, de 1980 a 1985, de 1986 a 1991, de 1992 a 1997 e 1998 a 2003, respectivamente. Estas figuras, que representam mapas temáticos classificados segundo os quadrantes do gráfico de Moran (Box map), apresentam áreas pertencentes ao quadrante Q1, os quais possuem valores altos de proporção de uso comercial 
cercados por vizinhos que também possuem valores altos. É importante observar que a maioria das áreas com valores altos se encontra na região correspondente à Zona Central de Negócios (ZCN), que aparece em destaque, bem como a localização dos Shoppings Galleria e Iguatemi. As áreas pertencentes ao quadrante Q2, ao contrário, indicam valores baixos para a variável proporção de uso comercial, cercado por vizinhos que também possuem valores baixos.

É importante ressaltar que a região estudada para o Shopping Galleria possui raio de 1700 metros, e de 1500 metros para o Shopping Iguatemi e para a ZCN. Essas regiões foram assim definidas de modo a não haver sobreposição entre as áreas, e de forma a abranger uma vizinhança representativa.

Observam-se também as áreas pertencentes ao quadrante Q3, os quais possuem valores baixos para a proporção de uso comercial, enquanto que os seus vizinhos possuem valores altos. Essa condição especial torna estas áreas potenciais ingressantes ao quadrante Q1. Além disso, constata-se por meio da análise das Figuras 5.1 a 5.5 algumas áreas pertencentes ao quadrante Q4, as quais possuem um alto valor de proporção de uso comercial e seus vizinhos possuem valores baixos. Essas áreas podem ter uma expressiva importância local por concentrarem serviços que atendam às áreas vizinhas.

Os índices de Moran obtidos para os respectivos períodos foram iguais a 0,2727; 0,2134; 0,2171; 0,2365 e 0,2497, o que indica um grau de autocorrelação espacial crescente, exceto pelo primeiro período, que apresentou um maior valor devido, muito provavelmente, ao fato de ser composto por registros de maior variabilidade, já que o período compreende valores da variável a partir de 1920 até 1979. 
Uma análise comparativa das Figuras 5.1 a 5.5, ainda que preliminar e apenas visual, já aponta modificações expressivas na variável em certas regiões da cidade, como, por exemplo, no entorno do Shopping Iguatemi, que foi implantado no segundo período considerado (1980).

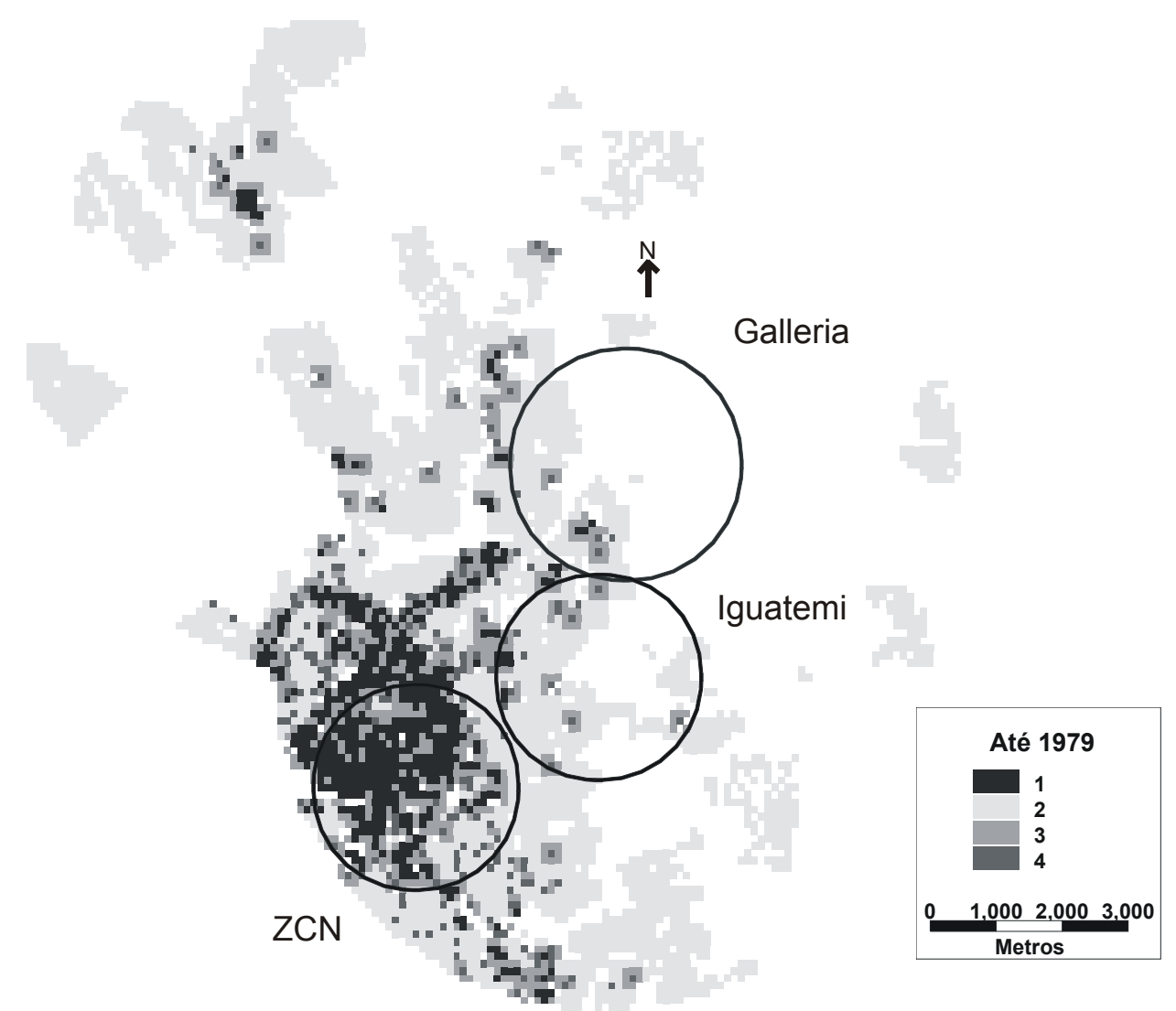

Figura 5.1: Box map representando a proporção de uso comercial até 1979 


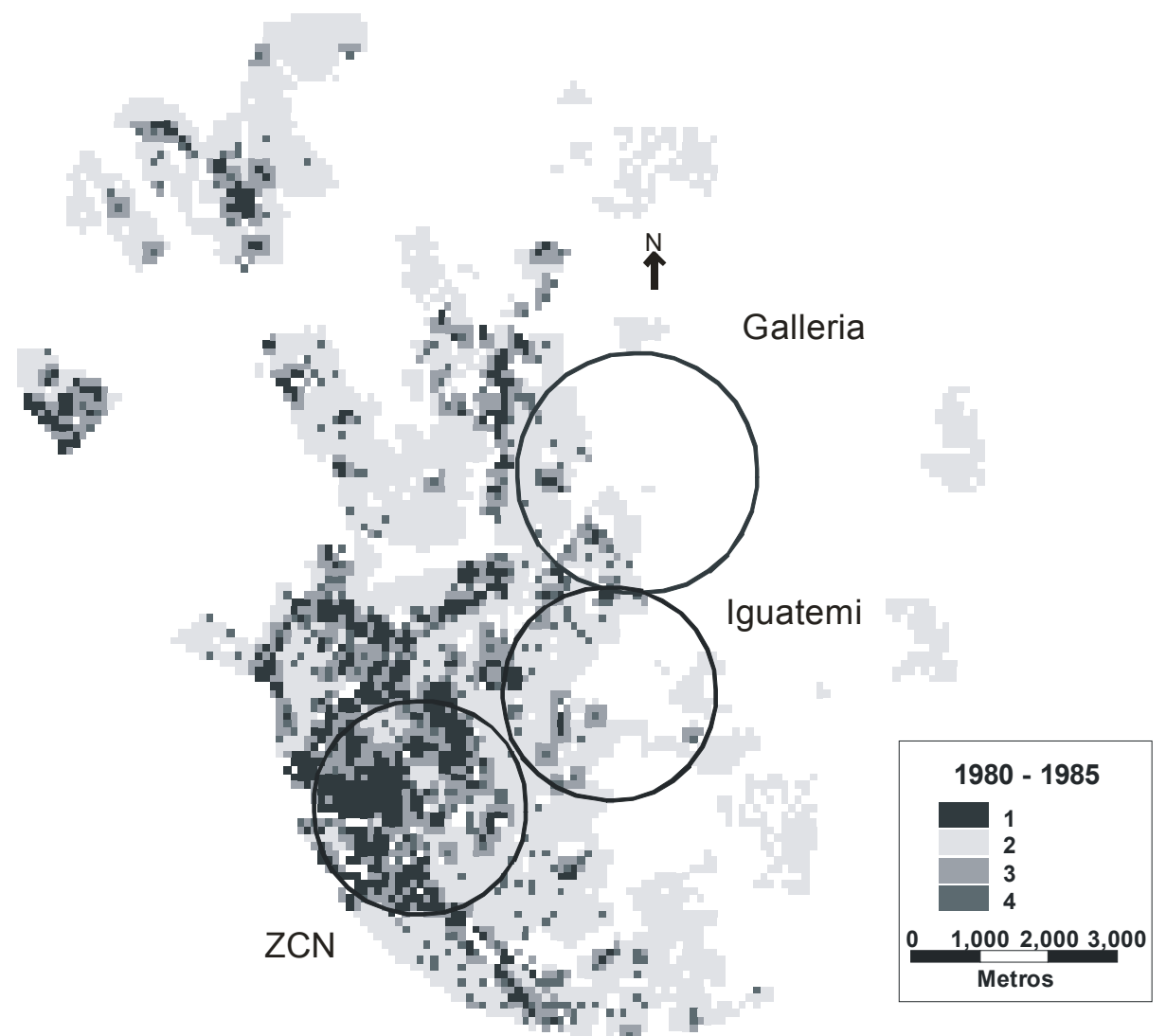

Figura 5.2: Box map representando a proporção de uso comercial de 1980 a 1985

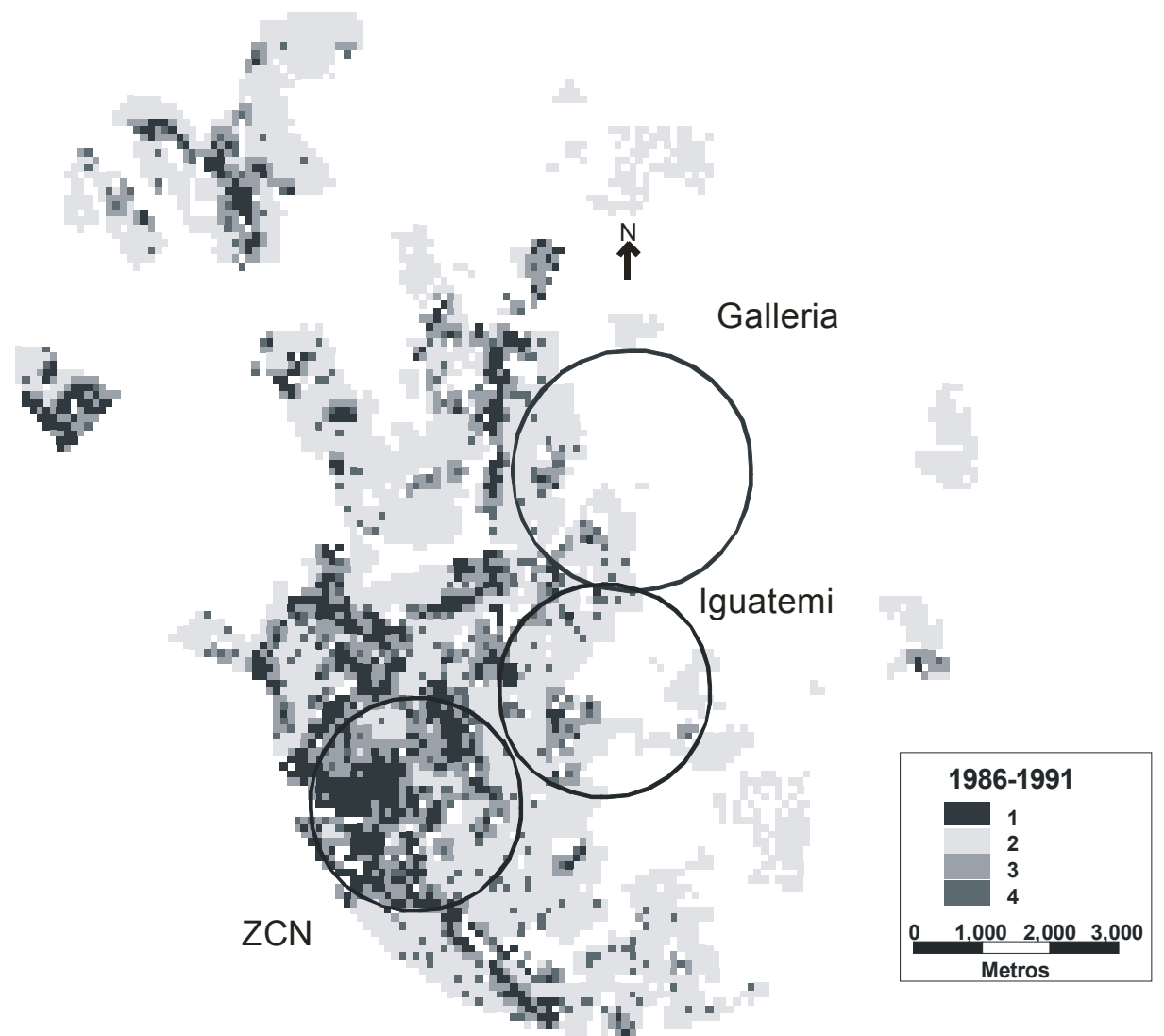

Figura 5.3: Box map representando a proporção de uso comercial de 1986 a 1991 


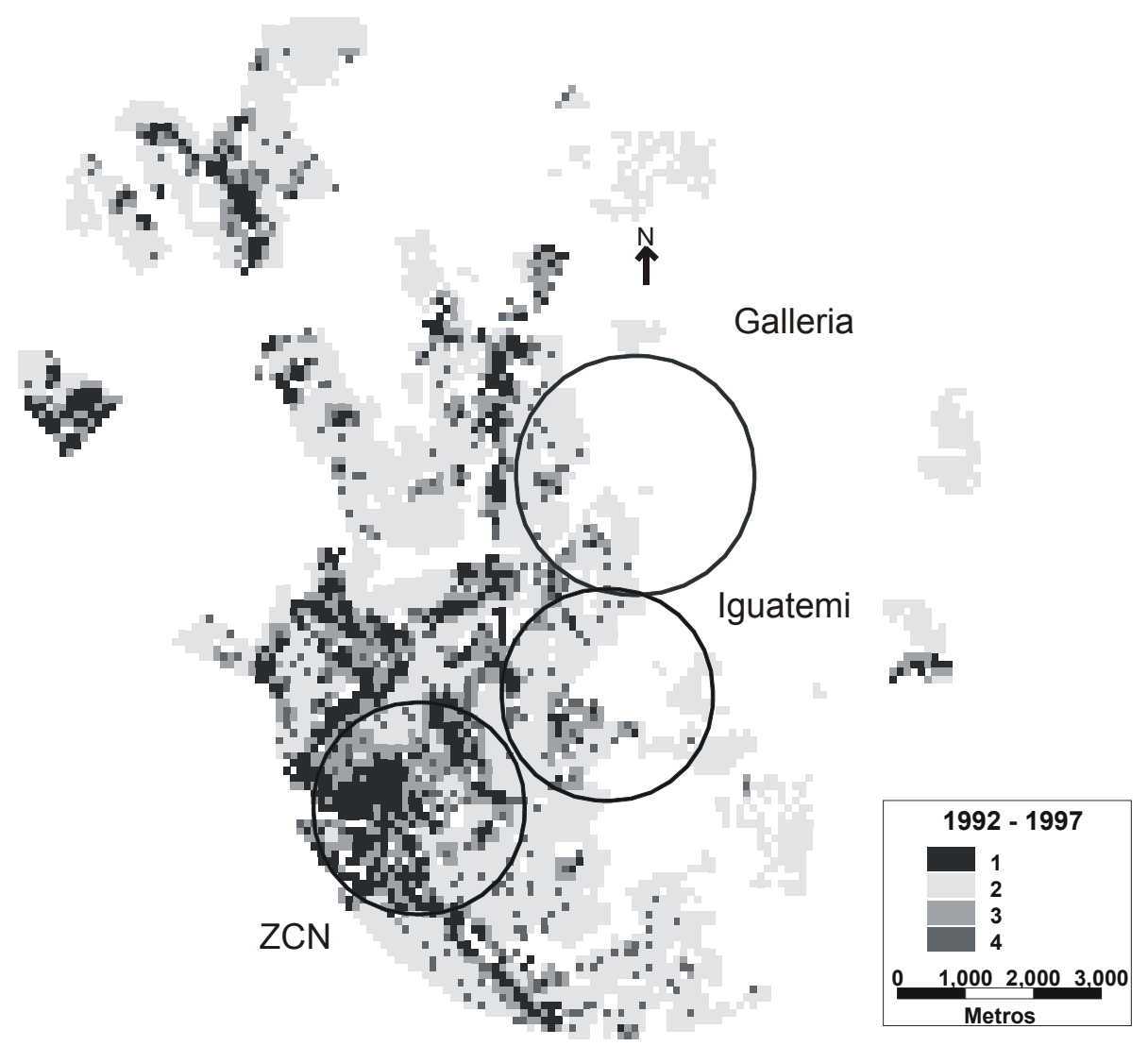

Figura 5.4: Box map representando a proporção de uso comercial de 1992 a 1997

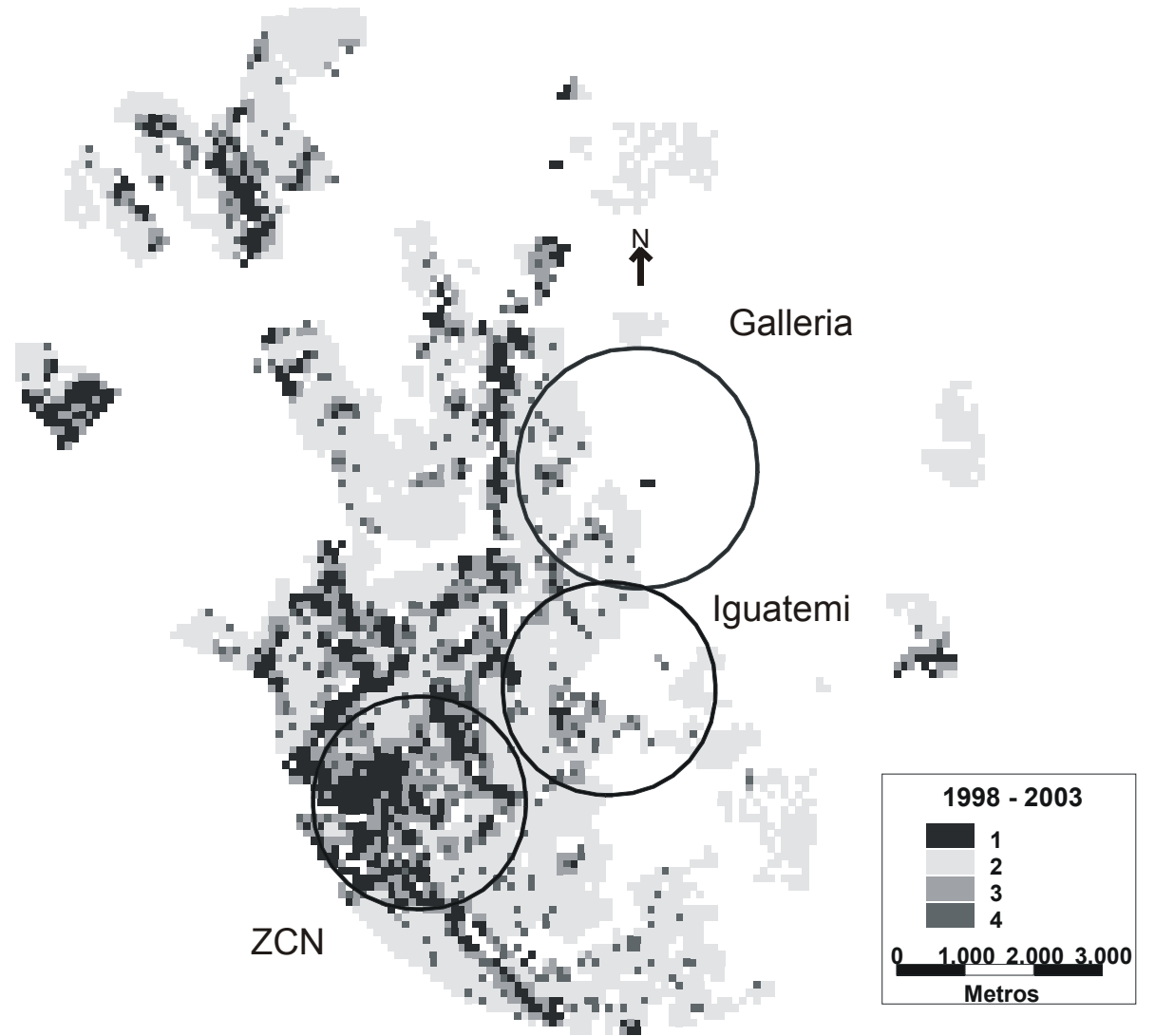

Figura 5.5: Box map representando a densidade proporção de uso comercial de 1998 a 2003 


\subsection{Outras variáveis consideradas}

Ao contrário do que foi observado para a variável proporção de uso comercial, a variável número absoluto de unidades comerciais não apresentou um padrão espacial bem definido em nenhum dos períodos analisados. Por este motivo, não é apresentada aqui a análise exploratória conduzida para a variável número absoluto de unidades comerciais. Isso não significa que a variável deva ser desprezada, uma vez que ela complementa a informação da variável proporção de uso comercial, como será comprovado na aplicação.

No caso das variáveis relacionadas à infra-estrutura de transportes, distância de cada célula à via mais próxima e densidade do sistema viário próximo a cada célula, também não foi conduzida a análise exploratória, uma vez que não se dispunha de registros temporais que permitissem separar os registros das variáveis ao longo do tempo.

Dessa forma, conforme é apresentado no item a seguir e já discutido na metodologia, duas combinações podem ser feitas por meio dos modelos espaciais: (i) combinação das duas variáveis de ocupação comercial (número absoluto de unidades comerciais e proporção de uso comercial) e (ii) combinação das duas variáveis de ocupação comercial (número absoluto de unidades comerciais e proporção de uso comercial) com variáveis de infra-estrutura de transportes (distância de cada célula à via mais próxima e densidade do sistema viário próximo a cada célula). Assim, são testadas diferentes alternativas para se obter um modelo que expresse de maneira razoável a inter-relação entre uso do solo com fins comerciais e uma medida da oferta de transportes ao longo do tempo. 


\subsection{Modelo I - resultados da validação para o período 1998-2003}

O modelo I foi construído com base apenas nas informações de ocupação comercial (número absoluto de unidades comerciais e proporção de uso comercial). Os resultados do modelo desenvolvido no presente estudo são apresentados na Figura 5.6, através de um mapa temático de classes compostas por uma combinação de variáveis:

(i) número absoluto de unidades comerciais. A variável, que continha valores de 0 a 323 unidades comerciais foi igualmente divididas em 5 classes (A, B, C, D, E):

\begin{tabular}{|c|c|c|c|c|}
\hline \multicolumn{5}{|c|}{ Número absoluto de unidades comerciais } \\
\hline A & B & C & D & E \\
\hline $0-65$ & $66-130$ & $131-205$ & $206-270$ & $271-323$ \\
\hline
\end{tabular}

(ii) proporção de uso comercial. Essa variável também foi dividida em 5 classes (1, 2, 3, 4, 5):

\begin{tabular}{|c|c|c|c|c|}
\hline \multicolumn{5}{|c|}{ Proporção de uso comercial } \\
\hline 1 & 2 & 3 & 4 & 5 \\
\hline 0 a $20 \%$ & $20 \%$ a $40 \%$ & $40 \%$ a $60 \%$ & $60 \%$ a $80 \%$ & $80 \%$ a $100 \%$ \\
\hline
\end{tabular}

Além disso, para facilitar a comparação, é fornecido também, na mesma figura, mapa temático dos dados reais referentes ao período 1998-2003. 


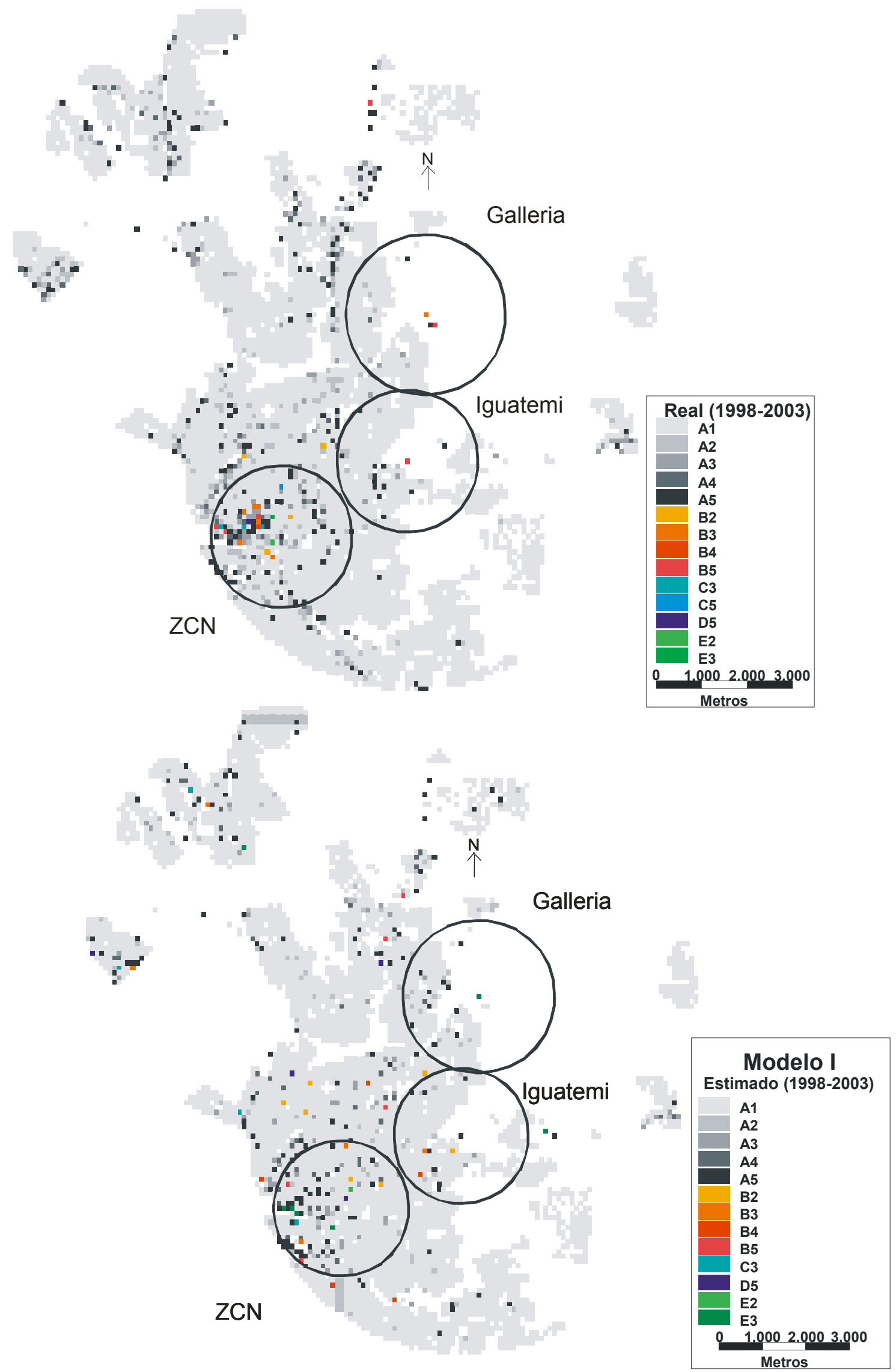

Figura 5.6: Ocupação comercial real x estimada pelo Modelo I no período 1998-2003 
Os resultados encontrados indicam um bom desempenho do modelo. $\mathrm{Na}$ fase de calibração, este apresentou 85,47 \% de acerto para os dados de validação e 85,60 \% de acerto para os dados de teste. Assim, este modelo foi aplicado para a previsão em um período subseqüente, de 2004 a 2009, conforme descrito no item 5.6. É importante observar que o resultado apresentado pela Figura 5.6 se refere à fase da validação do modelo (100 \% dos dados).

Apesar de o modelo ter apresentado um bom desempenho, para a análise dos PGVs é necessária uma abordagem mais detalhada, que será conduzida nos subitens a seguir.

\subsubsection{Modelo I - Validação - Shopping Galleria}

A Figura 5.7 é composta pela região estudada para o Shopping Galleria (1700 metros de raio), mostrando uma comparação da situação real e da estimada pelo Modelo I, para o período 1998-2003.

Como pode ser observado na Figura 5.7, o modelo não acerta completamente na célula central, representada pelo Shopping. Na ilustração real, a classe é B3, e o modelo estimou E3, portanto, ocorre um erro no número absoluto de unidades comerciais e um acerto na proporção de uso comercial.

Nas duas células bem próximas ao Shopping, o valor real é A5 e B5, e o modelo estimou a classe A1 para ambas as células, portanto, o modelo subestima esses valores. No entanto, nas imediações, o modelo parece captar a influência do crescimento de unidades comerciais da situação real, representada no cenário estimado pelos pontos escuros (A5). 


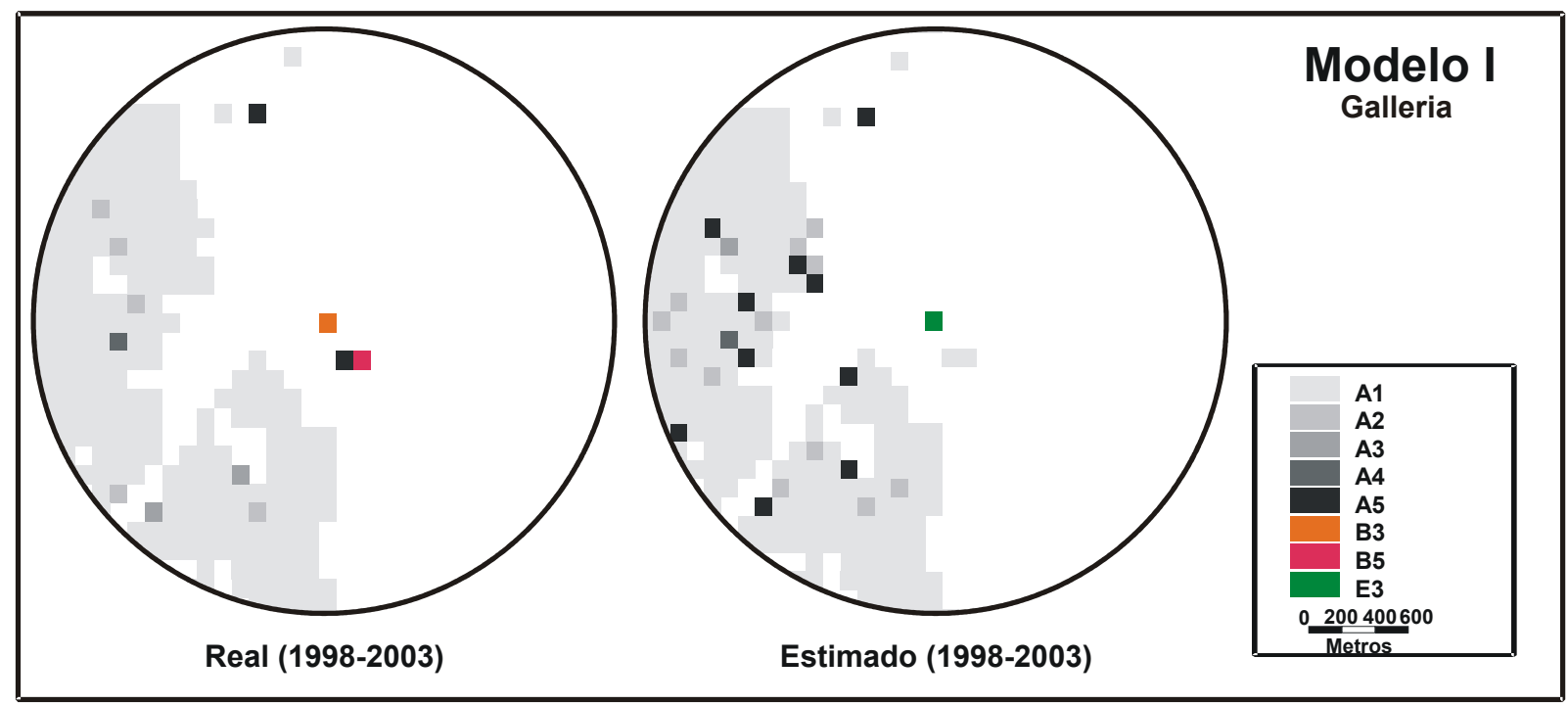

Figura 5.7: Real x Estimado Modelo I - Galleria

\subsubsection{Modelo I - Validação - Shopping Iguatemi}

A análise da comparação da situação real com a estimada pelo Modelo I para o Shopping Iguatemi é mostrada da Figura 5.8.

Assim como ocorreu para o Shopping Galleria, na célula central, que representa o Shopping, o modelo estima um valor diferente. Onde, na situação real, a classe é B5, o modelo estima A5, indicando novamente um erro parcial.

No entanto, ele aproxima as previsões nas vizinhanças, quando se observa a ocorrência da classe A5 (cor preta) no caso real e no estimado. Portanto, o modelo foi capaz de captar os locais onde se situam as classes com os maiores valores nas imediações da área analisada. 


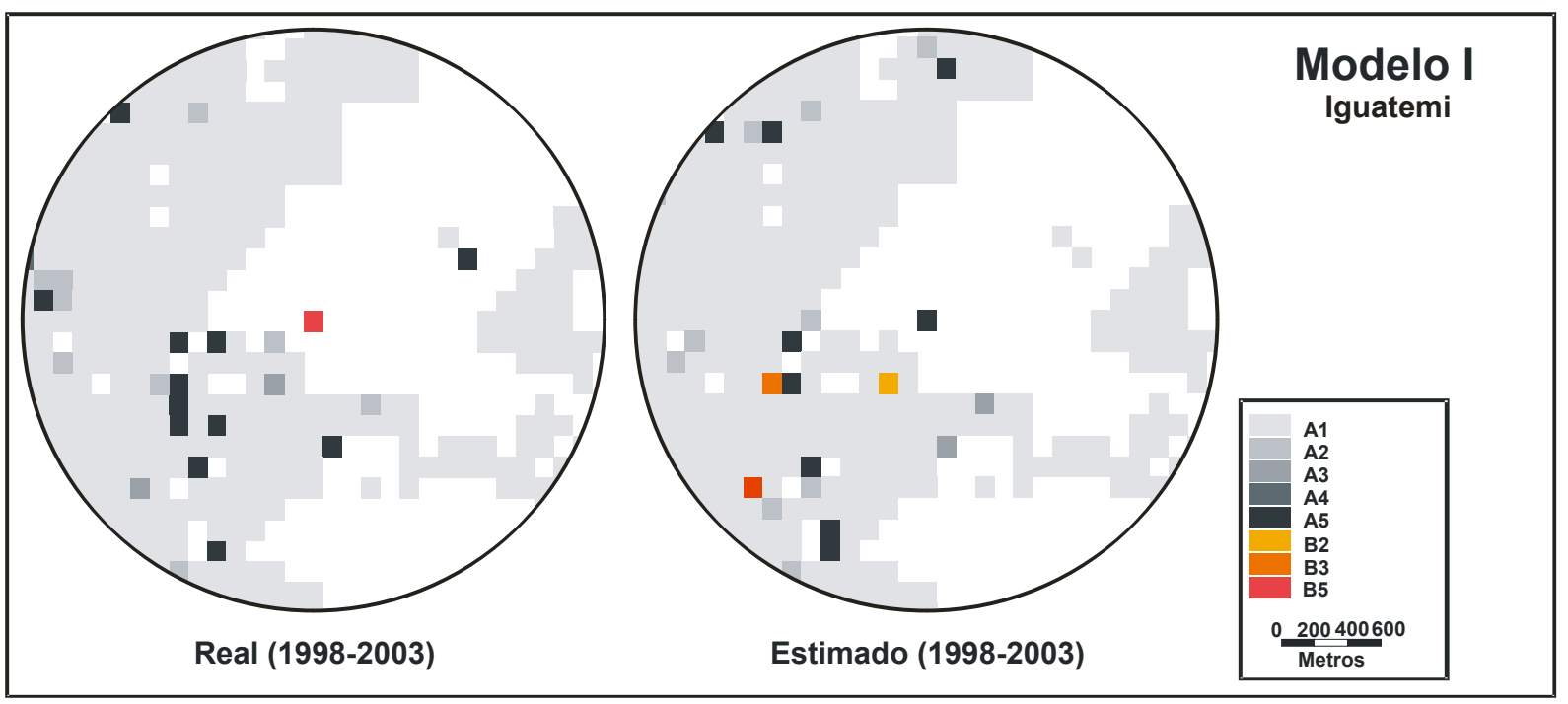

Figura 5.8: Real x Estimado Modelo I - Iguatemi

\subsubsection{Modelo I - Validação - ZCN}

A Figura 5.9 mostra a comparação da situação real com a estimativa do Modelo I para o caso da Zona Central de Negócios (ZCN).

Como o padrão de ocupação espacial neste caso é muito heterogêneo, uma análise visual fica bastante comprometida. Porém, pode-se afirmar que, de maneira geral, o modelo subestima os valores reais, uma vez que aparecem muitas células na classe A1. No entanto, ele consegue captar os locais onde há a ocorrência de classes com valores maiores.

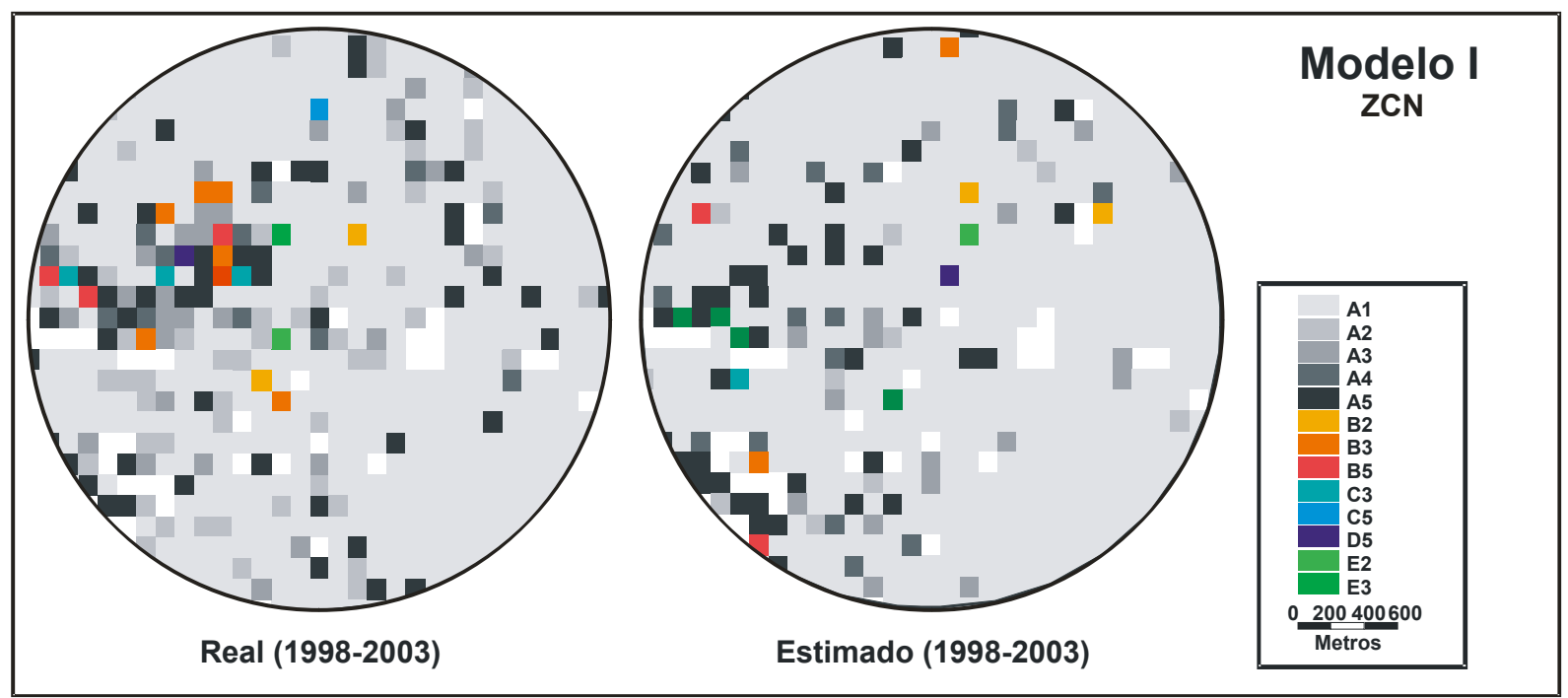

Figura 5.9: Real x Estimado Modelo I - ZCN 
Para a verificação da influência da incorporação de uma variável que representa a infraestrutura viária ao modelo "3 IN 1 OUT" proposto, foi construído o Modelo II, conforme é detalhado no item a seguir.

\subsection{Modelo II - resultados da validação para o período 1998-2003}

O Modelo II foi construído com base nas informações de ocupação comercial (número absoluto de unidades comerciais e proporção de uso comercial) e de infra-estrutura de transportes (distância de cada célula à via mais próxima e densidade do sistema viário próximo a cada célula). O resultado do modelo espacial desenvolvido nesta etapa é apresentado na Figura 5.10. Essa figura ilustra as variáveis combinadas número absoluto de unidades comerciais e proporção de uso comercial estimadas para o período 1998-2003 por meio do Modelo II. Além disso, para facilitar a comparação, é fornecido também, na mesma figura, mapa temático dos dados reais referentes ao período 1998-2003.

Da mesma forma que observado para o Modelo I, os resultados do Modelo II indicam um bom desempenho. $\mathrm{Na}$ fase de calibração do modelo, este apresentou 97,44\% de acerto nas classes para $25 \%$ dos dados de validação e $89,63 \%$ de acerto nas classes para os dados de teste. Assim, este modelo foi aplicado para a previsão em um período subseqüente, de 2004 a 2009, conforme descrito no item 5.7. É importante observar que o resultado apresentado pela Figura 5.10 se refere à fase da validação dos modelos (100\% dos dados). 


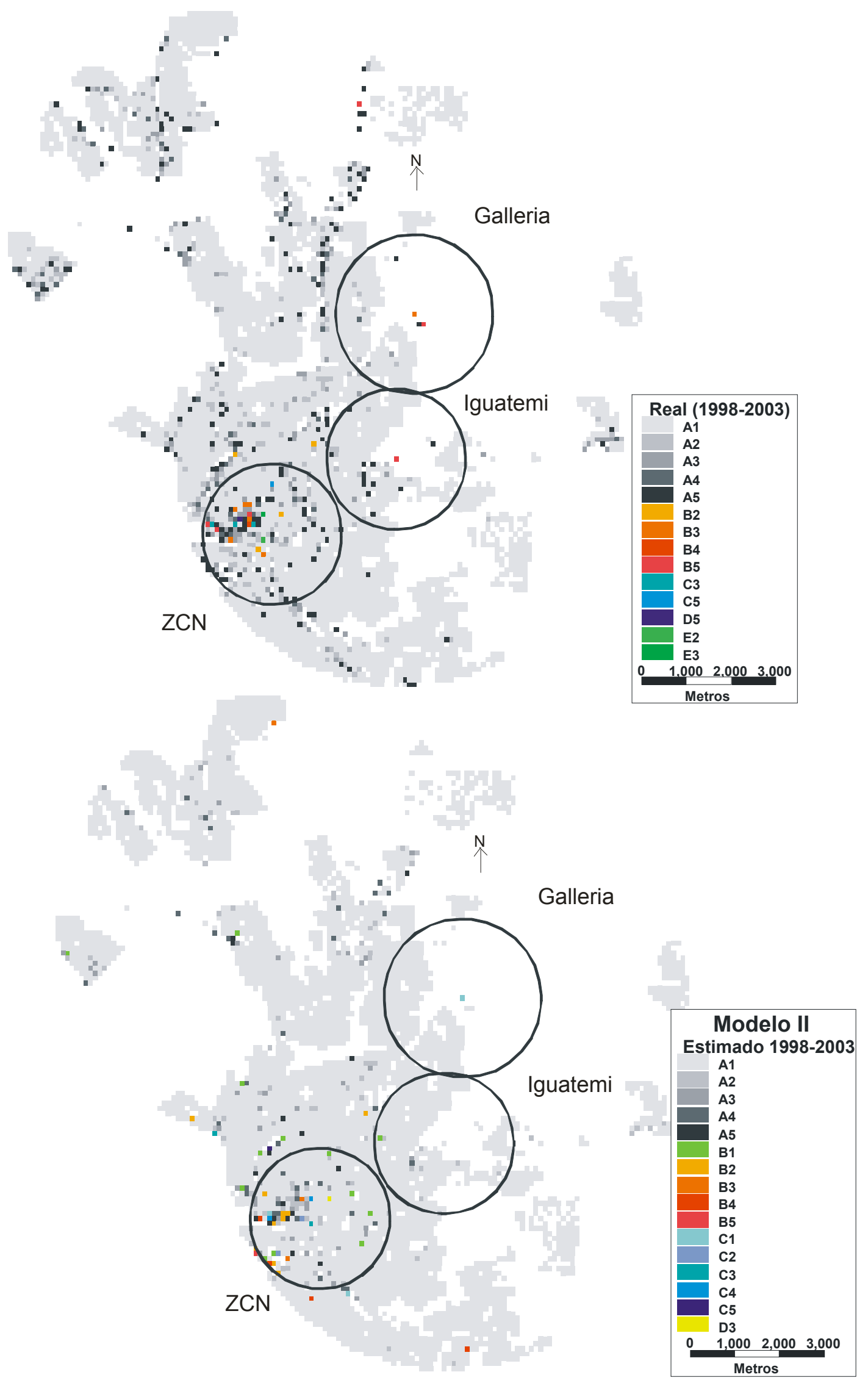

Figura 5.10: Ocupação comercial real x estimada pelo Modelo II no período 1998-2003 
Apesar do bom desempenho do Modelo II, procedeu-se a mesma análise realizada para o Modelo I, conforme é descrito nos subitens a seguir.

\subsubsection{Modelo II - Validação - Shopping Galleria}

A Figura 5.11 mostra a região analisada para o Shopping Galleria, mostrando uma comparação da situação real e da estimação pelo Modelo II, para o período 1998-2003.

Como pode ser observado na Figura 5.11, o modelo não acerta completamente na célula central que representa o Shopping, onde, na situação real atual a classe é B3 e o modelo estima C1. Portanto, ocorre um erro em ambas as classes da variável proporção de uso comercial e número absoluto de unidades comerciais, embora uma classe apresente um aumento e a outra uma redução.

Nas duas células bem próximas ao Shopping, o valor real é A5 e B5, e o modelo estimou a classe A1 para ambas as células, da mesma forma que para o Modelo I, portanto, subestima os valores. Já nas imediações, o modelo não foi capaz de captar nenhuma região com ocupação comercial mais intensa.

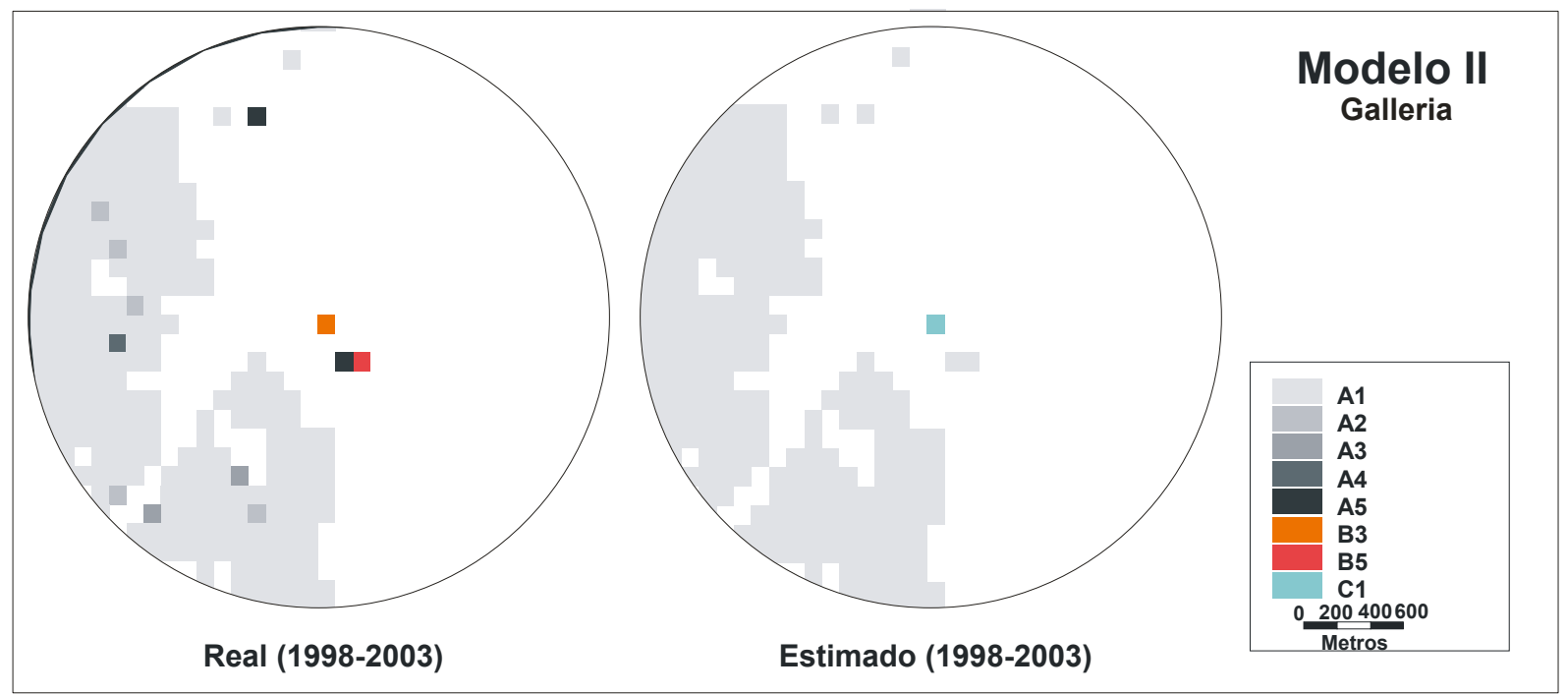

Figura 5.11: Real x Estimado Modelo II - Galleria 


\subsubsection{Modelo II - Validação - Shopping Iguatemi}

Para o Shopping Iguatemi, a análise da comparação da situação real com a estimada pelo Modelo II é mostrada da Figura 5.12.

A célula central, que representa o Shopping, apresentou na estimação uma classe diferente da situação real. Onde, na situação real, a classe é B5, o modelo estima A1, apresentando um resultado pior que no Modelo I, que estimou a classe A5.

Nas estimativas para a vizinhança, o modelo captou levemente dois locais onde se situam as maiores classes no cenário real: (i) no cenário estimado, aparece a classe B1 (verde claro) e na situação real aparecem as classes A3 e A5 e (ii) onde aparece uma célula A4 na estimativa, aparece uma região composta por valores A5, na situação real.

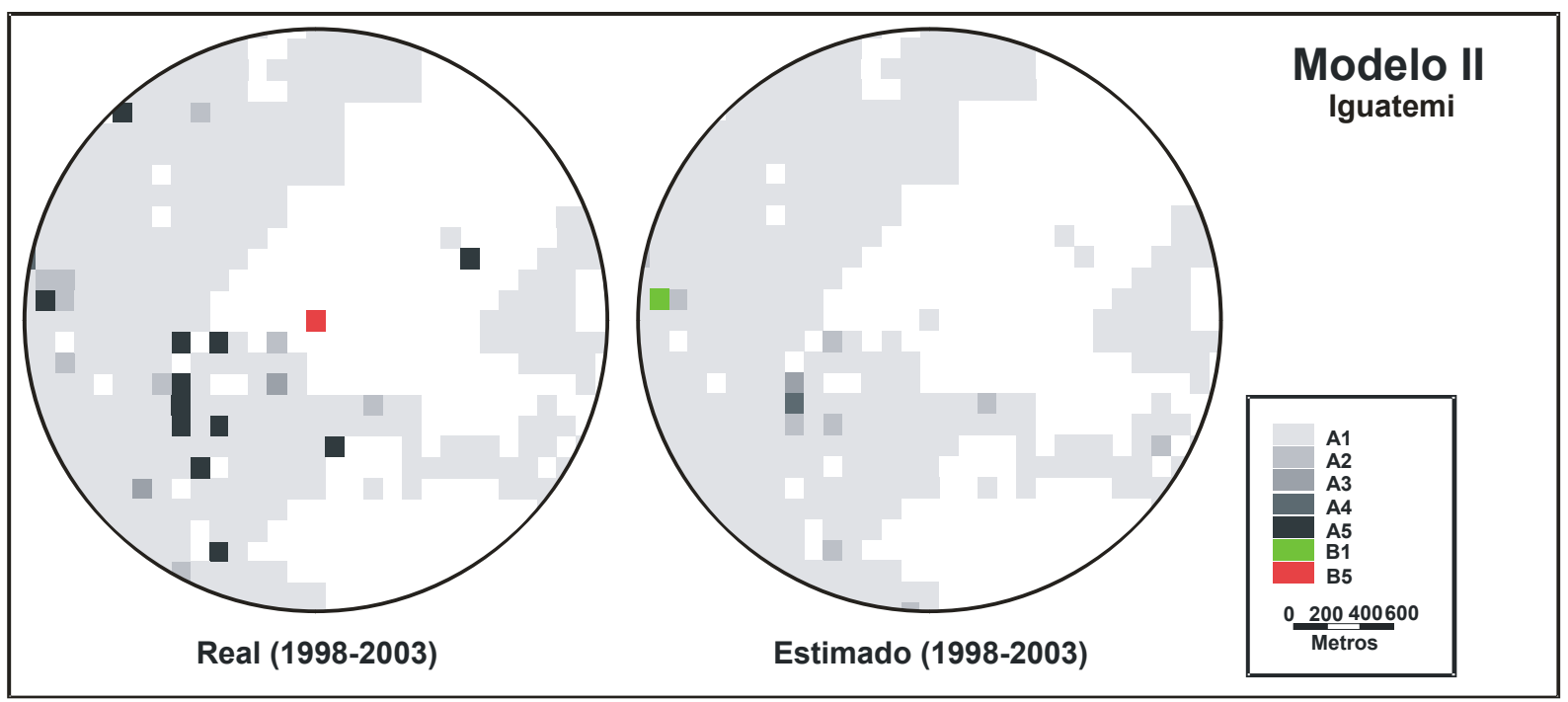

Figura 5.12: Real x Estimado Modelo II - Iguatemi 


\subsubsection{Modelo II - Validação - ZCN}

A comparação da situação real com a estimativa do Modelo I para o caso da Zona Central de Negócios (ZCN) é mostrada na Figura 5.13.

Da mesma forma que para o Modelo I, o Modelo II consegue captar o local onde há a ocorrência de classes maiores. Porém, a estimativa deste modelo se mostra bem mais conservadora que a observada no Modelo I, uma vez que prevê menos células situadas em classes mais elevadas.

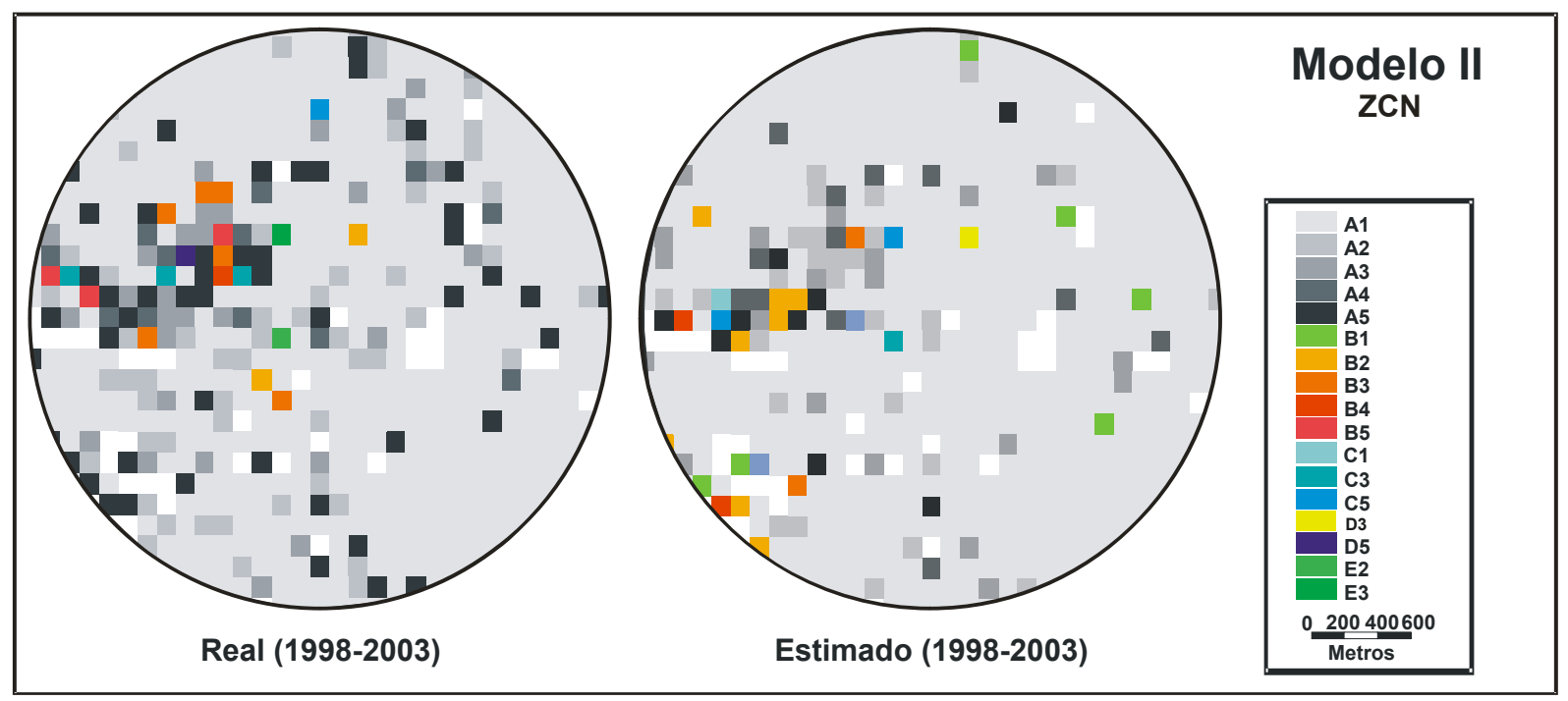

Figura 5.13: Real x Estimado Modelo II - ZCN

\subsection{Avaliação comparativa dos dois modelos}

Para avaliar qual dos dois modelos desenvolvidos apresentou o melhor desempenho, procedeu-se à analise do mapa temático contendo as proporções de acertos e erros, parciais e totais de cada modelo. A Figura 5.14 apresenta os resultados para o Modelo I e a Figura 5.15, para o Modelo II. 


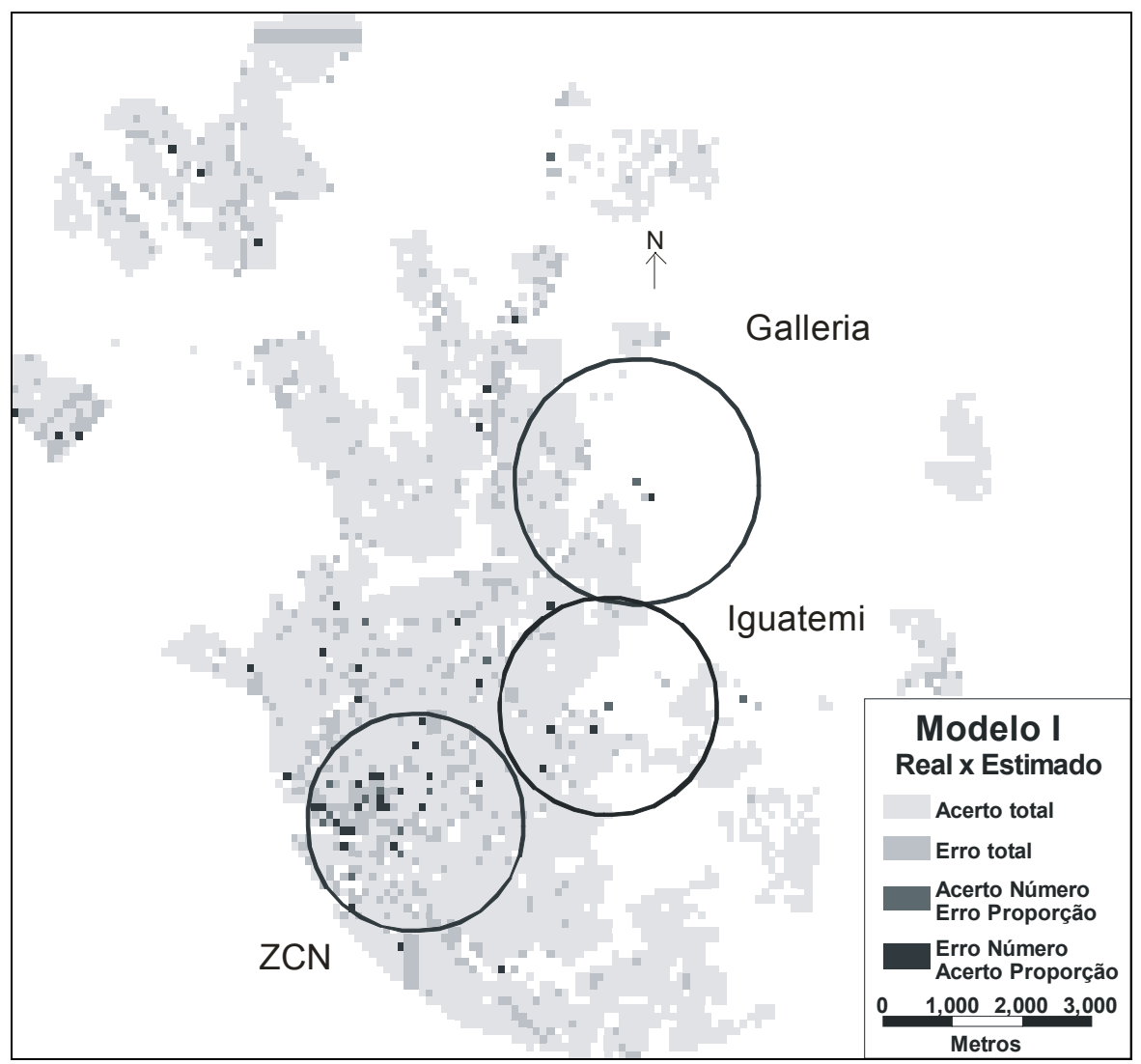

Figura 5.14: Comparação da situação real x estimada pelo Modelo I no período 1998-2003

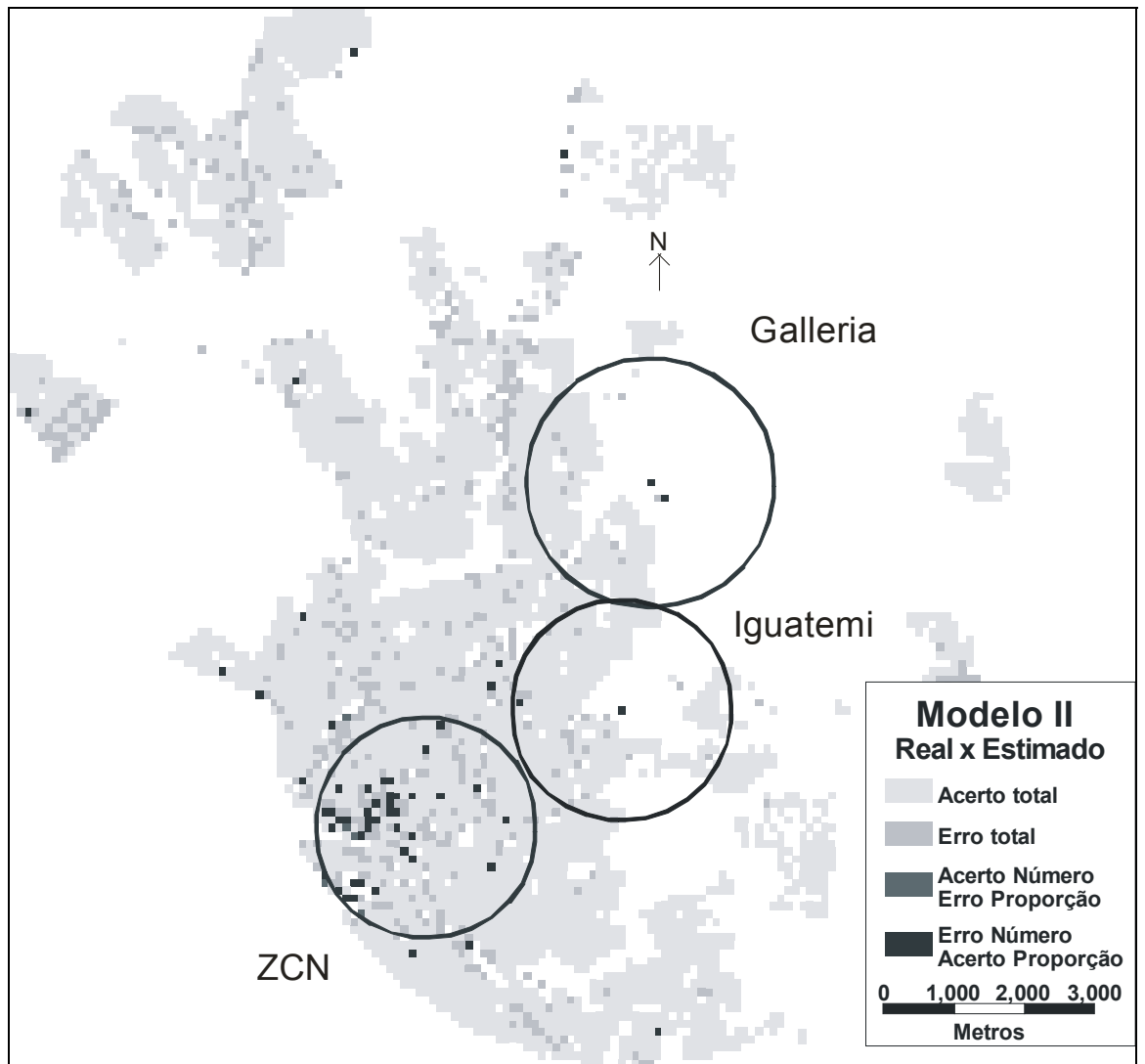

Figura 5.15: Comparação da situação real x estimada pelo Modelo II no período 1998-2003 
Quando ocorreu o acerto em ambas as parcelas que compunham a variável alfanumérica número absoluto de unidades comerciais e proporção de uso comercial, a célula é representada pela classe “acerto total". Para erro em ambas as variáveis, a classe é "erro total". Quando ocorreu acerto na variável número absoluto de unidades comerciais e erro na proporção de uso comercial ou vice-versa, foram considerados, respectivamente, os valores "acerto número/erro proporção" e "erro número/acerto proporção".

Adicionalmente, apresenta-se nas Tabelas 5.1 e 5.2 as proporções de acertos e erros, totais e parciais dos Modelos I e II. É importante ressaltar que esses valores são para o conjunto total analisado, não se restringindo às regiões estudadas.

Tabela 5.1: Proporções de acertos parciais (por classe) do Modelo I

\begin{tabular}{|c|c|c|c|c|}
\hline CLASSE REAL & ACERTO & $\begin{array}{l}\text { ACERTO Num } \\
\text { ERRO Prop }\end{array}$ & $\begin{array}{c}\text { ERRO Num } \\
\text { ACERTO Prop }\end{array}$ & ERRO \\
\hline $\mathrm{A1}$ & $84,62 \%$ & $6,38 \%$ & - & $0,23 \%$ \\
\hline A2 & $0,39 \%$ & $2,57 \%$ & $0,02 \%$ & $0,02 \%$ \\
\hline A3 & $0,25 \%$ & $0,97 \%$ & - & - \\
\hline A4 & $0,23 \%$ & $0,64 \%$ & - & $0,02 \%$ \\
\hline A5 & $0,54 \%$ & $2,18 \%$ & $0,10 \%$ & $0,06 \%$ \\
\hline B1 & - & - & - & - \\
\hline B2 & - & - & $0,02 \%$ & $0,12 \%$ \\
\hline B3 & - & - & $0,02 \%$ & $0,08 \%$ \\
\hline B4 & - & - & - & $0,10 \%$ \\
\hline B5 & - & - & $0,04 \%$ & $0,06 \%$ \\
\hline C1 & - & - & - & - \\
\hline C2 & - & - & - & - \\
\hline C3 & - & - & - & $0,08 \%$ \\
\hline C4 & - & - & - & - \\
\hline C5 & - & - & - & - \\
\hline D1 & - & - & - & - \\
\hline D2 & - & - & - & - \\
\hline D3 & - & - & - & - \\
\hline D4 & - & - & - & - \\
\hline D5 & - & - & - & $0,08 \%$ \\
\hline E1 & - & - & - & - \\
\hline$\overline{E 2}$ & - & - & $0,02 \%$ & - \\
\hline E3 & - & - & $0,08 \%$ & $0,06 \%$ \\
\hline$\overline{E 4}$ & - & - & - & - \\
\hline E5 & - & - & - & - \\
\hline SOMA & $86,02 \%$ & $12,74 \%$ & $0,31 \%$ & $0,93 \%$ \\
\hline
\end{tabular}


Tabela 5.2: Proporções de acertos parciais (por classe) do Modelo II

\begin{tabular}{|c|c|c|c|c|}
\hline CLASSE REAL & ACERTO & $\begin{array}{l}\text { ACERTO Num } \\
\text { ERRO Prop }\end{array}$ & $\begin{array}{c}\text { ERRO Num } \\
\text { ACERTO Prop }\end{array}$ & ERRO \\
\hline A1 & $87,90 \%$ & $7,00 \%$ & - & $0,23 \%$ \\
\hline A2 & $0,39 \%$ & $1,48 \%$ & - & $0,14 \%$ \\
\hline A3 & $0,19 \%$ & $0,72 \%$ & - & - \\
\hline A4 & $0,10 \%$ & $0,60 \%$ & - & $0,04 \%$ \\
\hline A5 & $0,14 \%$ & $0,21 \%$ & - & - \\
\hline B1 & - & $0,02 \%$ & - & $0,25 \%$ \\
\hline B2 & - & - & $0,04 \%$ & $0,16 \%$ \\
\hline B3 & - & - & - & $0,06 \%$ \\
\hline B4 & - & - & - & $0,08 \%$ \\
\hline B5 & - & - & $0,02 \%$ & - \\
\hline C1 & - & - & - & $0,06 \%$ \\
\hline $\mathrm{C2}$ & - & - & - & $0,04 \%$ \\
\hline C3 & - & - & - & $0,04 \%$ \\
\hline $\mathrm{C4}$ & - & - & $0,02 \%$ & $0,02 \%$ \\
\hline C5 & - & - & $0,02 \%$ & - \\
\hline D1 & - & - & - & - \\
\hline D2 & - & - & - & - \\
\hline D3 & - & - & $0,02 \%$ & - \\
\hline D4 & - & - & - & - \\
\hline D5 & - & - & - & - \\
\hline E1 & - & - & - & - \\
\hline E2 & - & - & - & - \\
\hline E3 & - & - & - & - \\
\hline E4 & - & - & - & - \\
\hline E5 & - & - & - & - \\
\hline SOMA & $88,72 \%$ & $10,02 \%$ & $0,12 \%$ & $1,13 \%$ \\
\hline
\end{tabular}

Analisando-se as Tabelas 5.1 e 5.2, pode-se observar que o Modelo II possui maior percentual de acerto total $(88,72 \%)$ contra $86,02 \%$ do Modelo I. No entanto, o Modelo II também possui maior percentual de erro total $(1,13 \%)$ em relação ao Modelo I $(0,93 \%)$. Portanto, não é possível concluir qual modelo é o melhor somente pela análise numérica.

Para auxiliar na escolha do melhor modelo somente analisando-se as regiões em estudo Shoppings Galleria e Iguatemi e ZCN. As Figuras 5.16, 5.17 e 5.18 mostram uma análise gráfica dos Modelos I e II.

A Figura 5.16 mostra a ilustração da comparação dos modelos para o Shopping Galleria e revela que no Modelo I há mais células na classe "erro total” do que observado no Modelo II. No entanto, a célula que representa o Shopping em si não apresenta uma alteração relevante, uma vez que no Modelo I ocorre "acerto no número e erro na proporção" e no Modelo II, "erro no 
número e acerto na proporção". Para as duas células bem próximas ao Shopping ocorre o mesmo.

Neste caso, o modelo selecionado como melhor é o Modelo II.

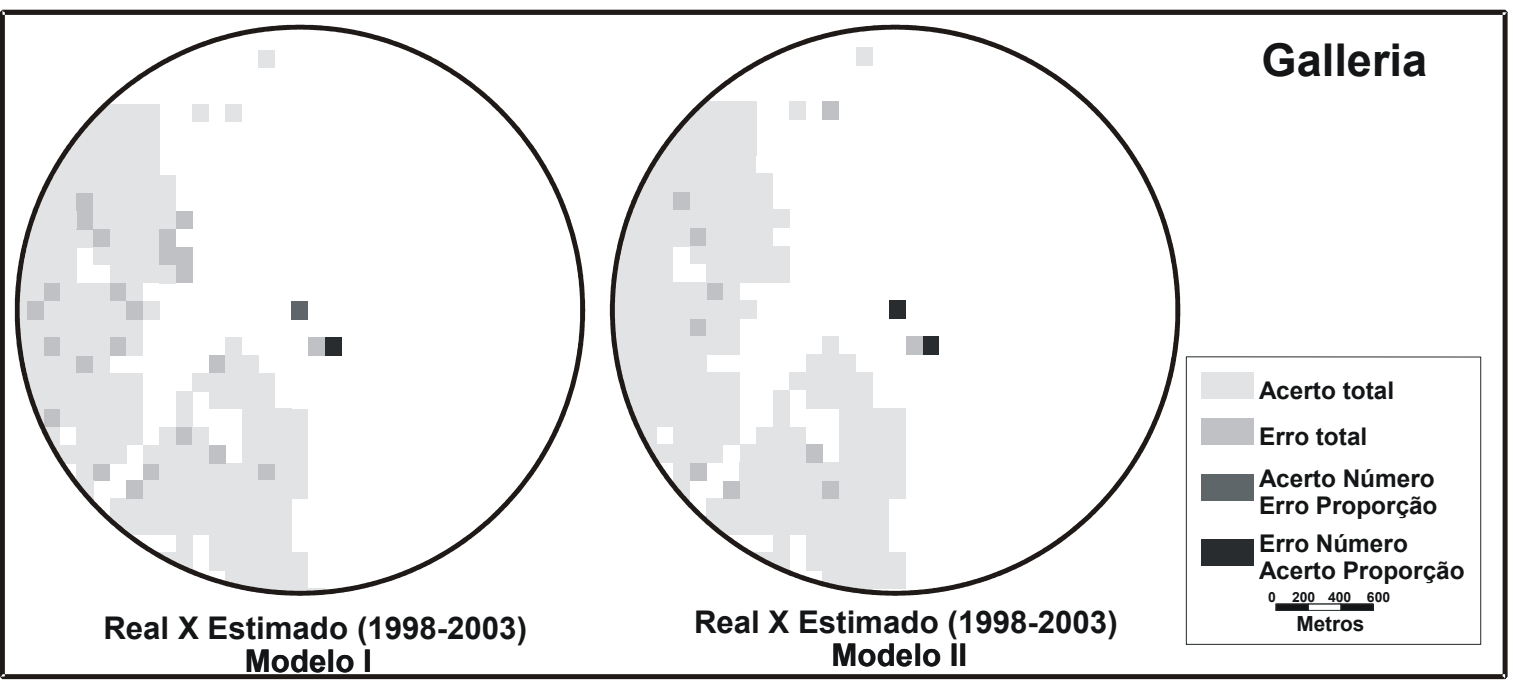

Figura 5.16: Comparação da estimação dos modelos - Galleria

Para a comparação dos modelos na área em estudo para o Shopping Iguatemi (Figura 5.17), o erro total ocorre praticamente com a mesma intensidade em ambos os modelos, porém, o Modelo I contém mais células com erros parciais. Também para esta região o Modelo II teve melhor desempenho.

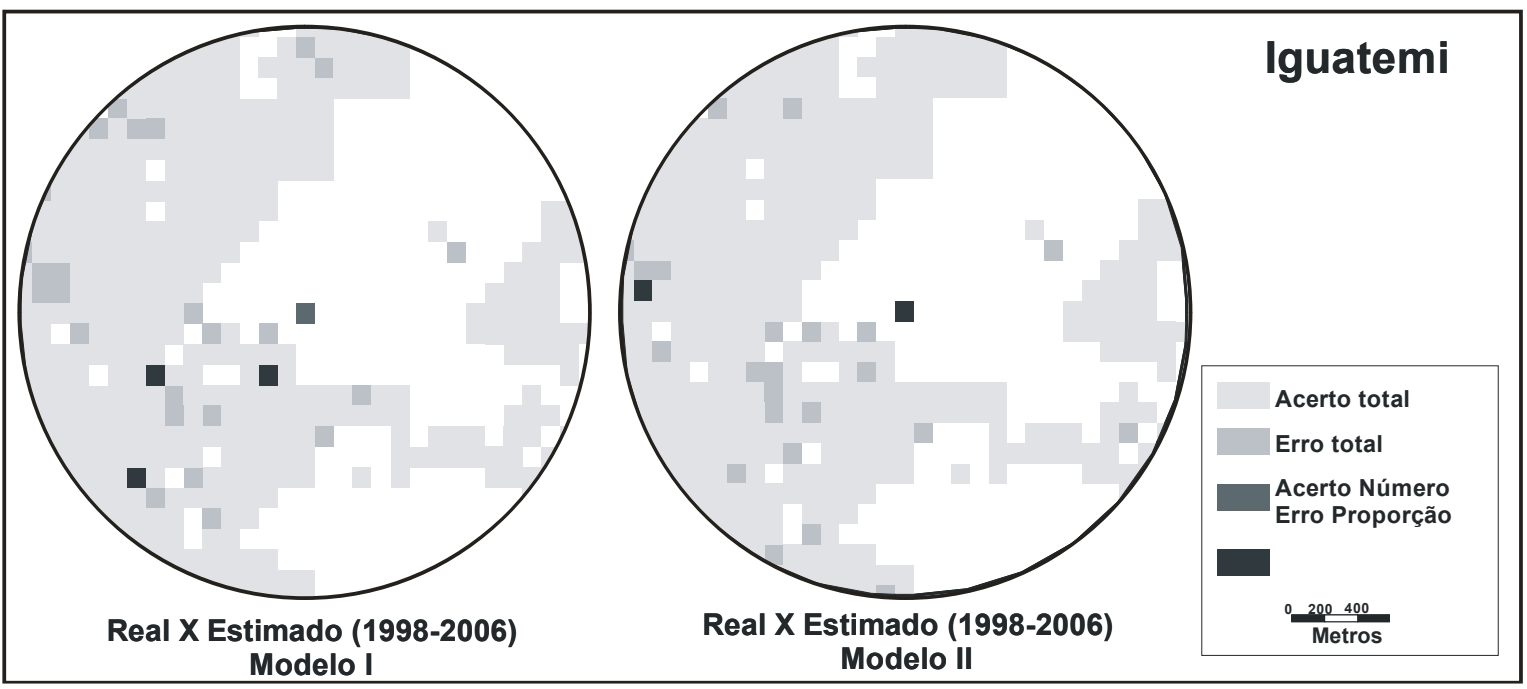

Figura 5.17: Comparação da estimação dos modelos - Iguatemi 
A comparação dos modelos para a ZCN está mostrada na Figura 5.18. Observa-se, ainda que não claramente, que o Modelo I contém mais ocorrências de erro total. Já o Modelo II, contém maior ocorrência da classe "erro no número e acerto na proporção". Neste caso, o Modelo II é também considerado como melhor.

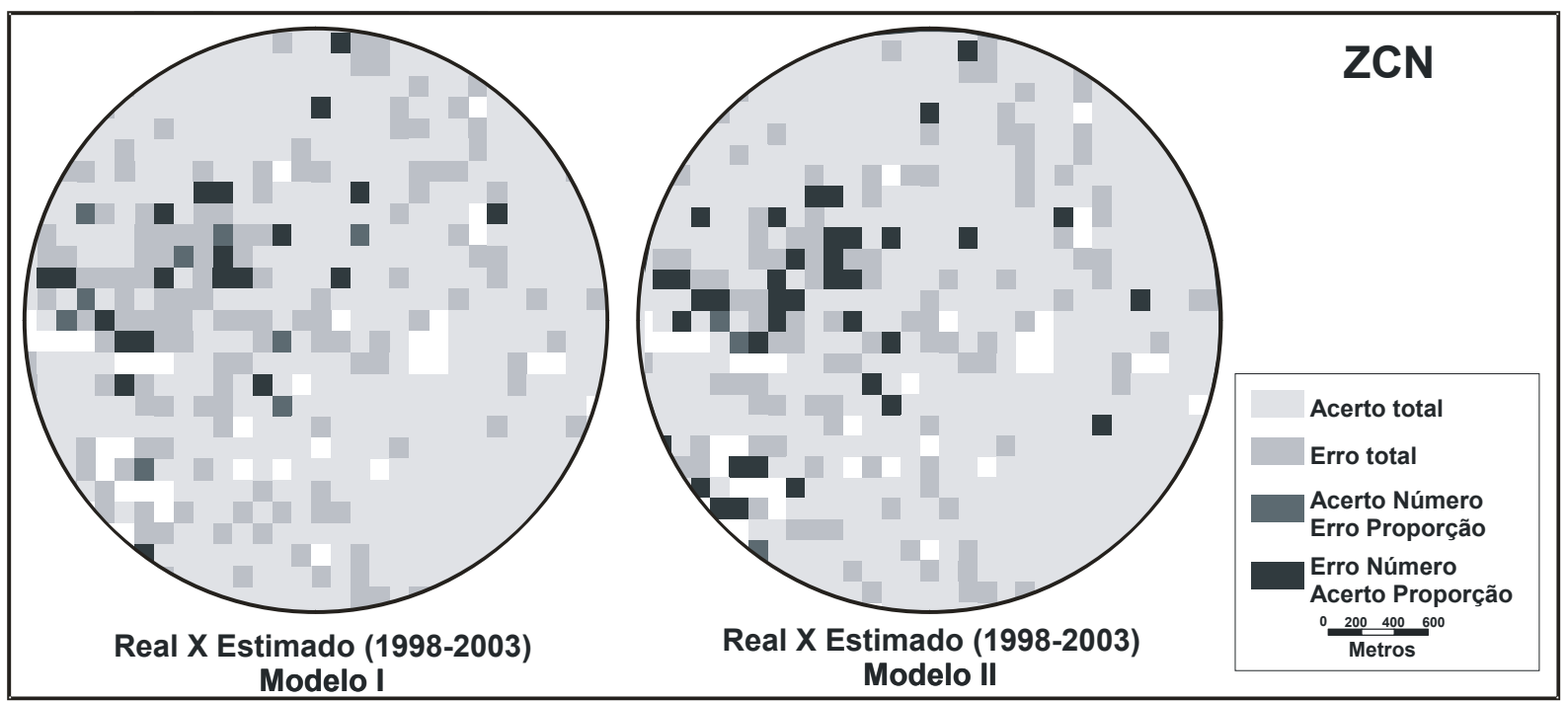

Figura 5.18: Comparação da estimação dos modelos - ZCN

Apesar do Modelo II ter apresentado uma ligeira superioridade em relação ao Modelo I, é interessante observar o que acontece com as projeções nos dois casos, em particular com as regiões ao redor dos dois Shoppings estudados, que são o foco desse estudo.

\subsection{Modelo I - resultados da previsão para o período 2004-2009}

Em uma tentativa de se visualizar o cenário para um período de projeção no futuro, aplicou-se o modelo espacial determinado anteriormente para se estimar a ocupação comercial no período 2004-2009. A Figura 5.19 ilustra o mapa temático segundo as classes de variáveis alfanuméricas descritas anteriormente, relacionadas à ocupação comercial, com a estimativa para o período 2004-2009. 


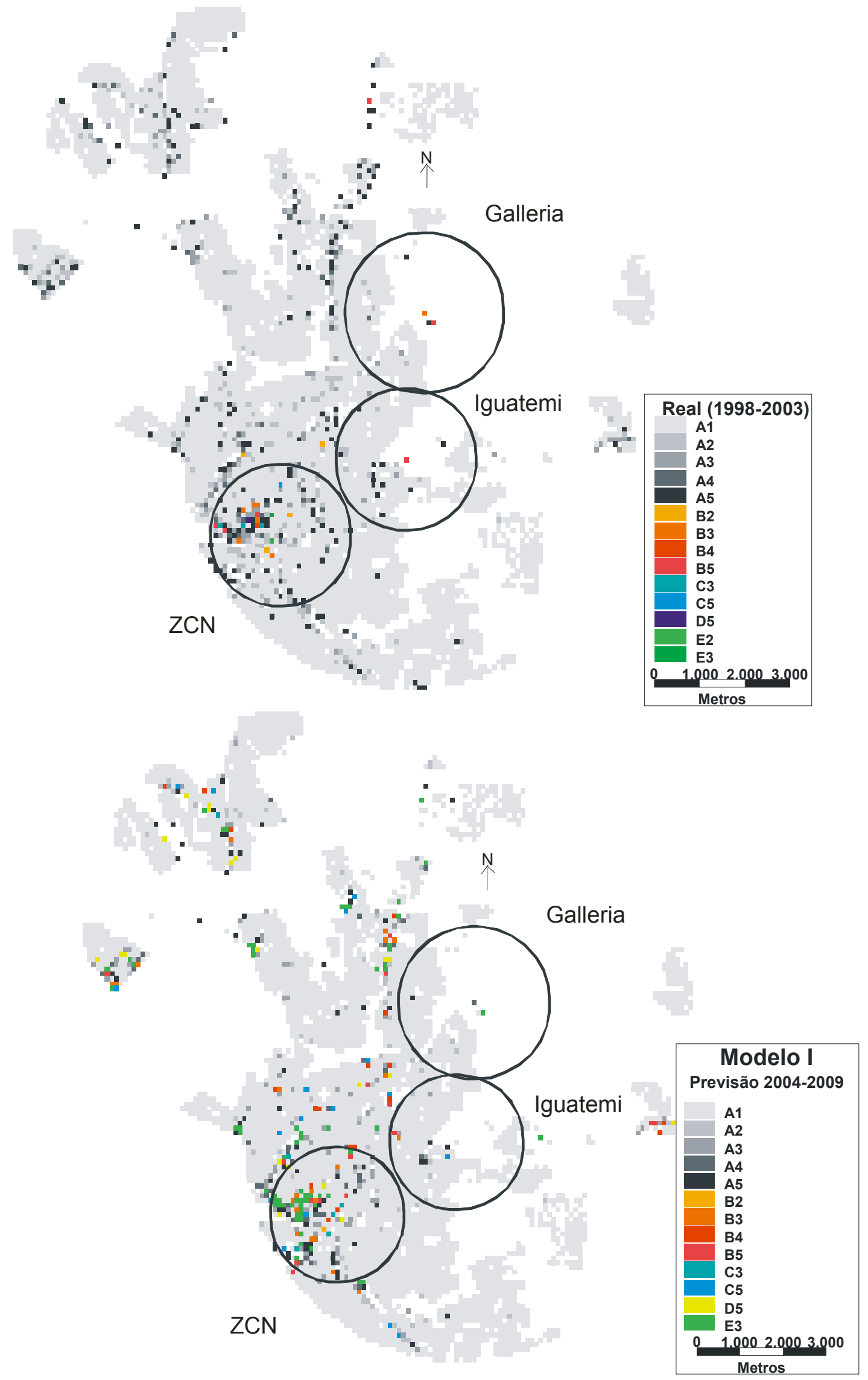

Figura 5.19: Ocupação comercial real x prevista pelo Modelo I no período 2004-2009 
Embora a previsão para toda a área analisada seja importante para fins de planejamento, os resultados da previsão ao redor dos Shoppings Centers Galleria e Iguatemi são particularmente relevantes para o presente estudo. Assim, nos subitens a seguir, são apresentadas as análises para os Shoppings, bem como para a região da ZCN.

\subsubsection{Modelo I - Previsão - Shopping Galleria}

A previsão do Modelo I para o Shopping Galleria está representada pela Figura 5.20. Da mesma forma como ocorreu para a fase de validação, o modelo parece não ser capaz de representar a célula que contém o Shopping, pois a classe real hoje é B3 e o modelo previu como sendo A4 no período subseqüente. Nesse caso, o erro foi para ambas as parcelas da variável, sendo que houve uma redução no número absoluto de unidades comerciais e um aumento na proporção de uso comercial.

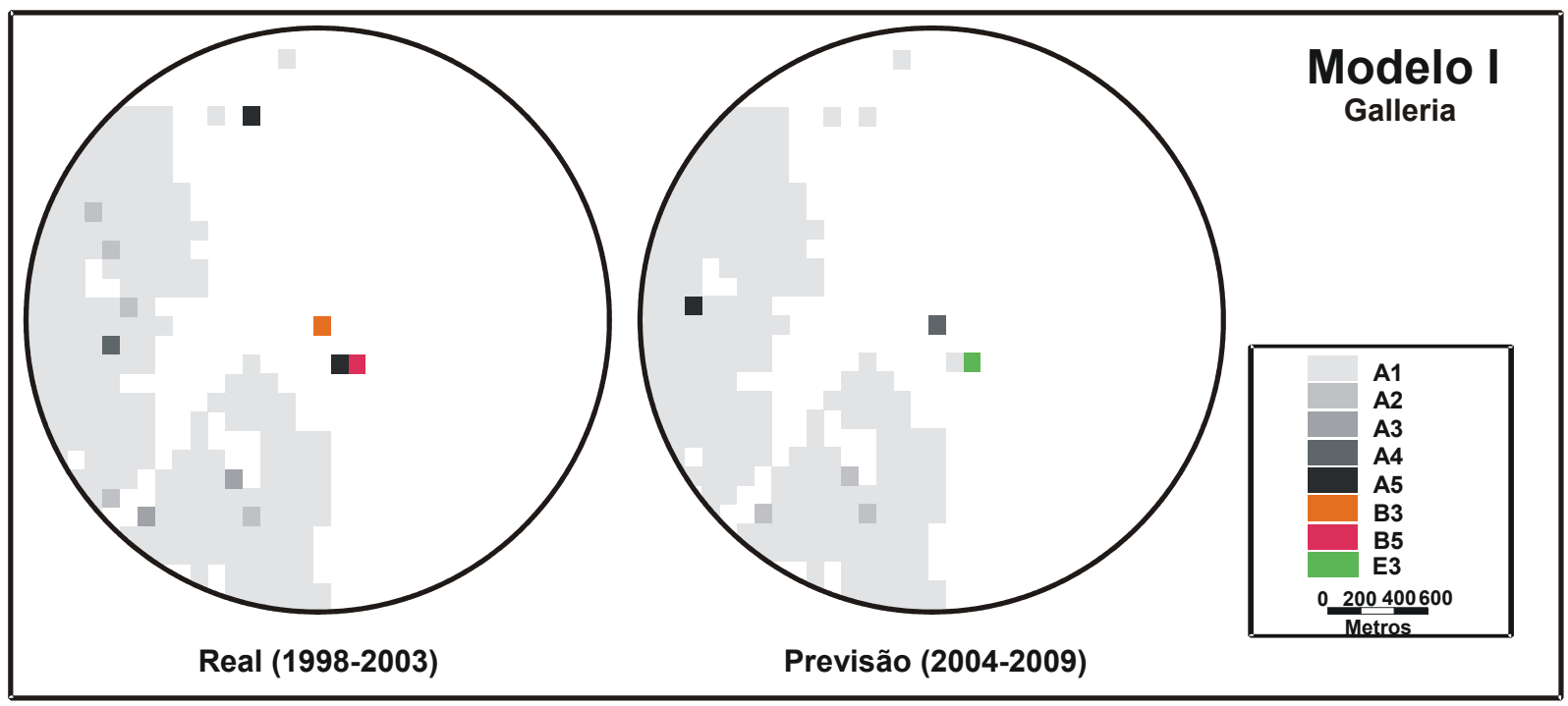

Figura 5.20: Real x Previsão Modelo I - Galleria

Nas duas células bem próximas ao Shopping o modelo altera significativamente apenas um dos valores (onde era B5 se torna E3), porém, para a outra célula, ele parece subestimar a classe 
da situação real (de A5 para A1). Nas zonas periféricas ele capta razoavelmente o crescimento das classes que é observado nas imediações no caso real, prevendo apenas uma célula com valor A5 e outras três com valor A2.

\subsubsection{Modelo I-Previsão - Shopping Iguatemi}

Para a comparação da situação real com a previsão do Modelo I para o Shopping Iguatemi, a Figura 5.21 indica que o modelo conseguiu captar os locais onde as classes são mais altas, apesar de não acertar exatamente as classes em si. No modelo há a ocorrência de uma célula B3, B5 e C4, enquanto que no caso real atual há mais classes A5.

No entanto, o modelo erra na variável número absoluto de unidades comerciais e subestima significativamente a célula que representa o Shopping em si na variável proporção de uso comercial, que na situação real pertence hoje à classe B5 e é previsto como A1.

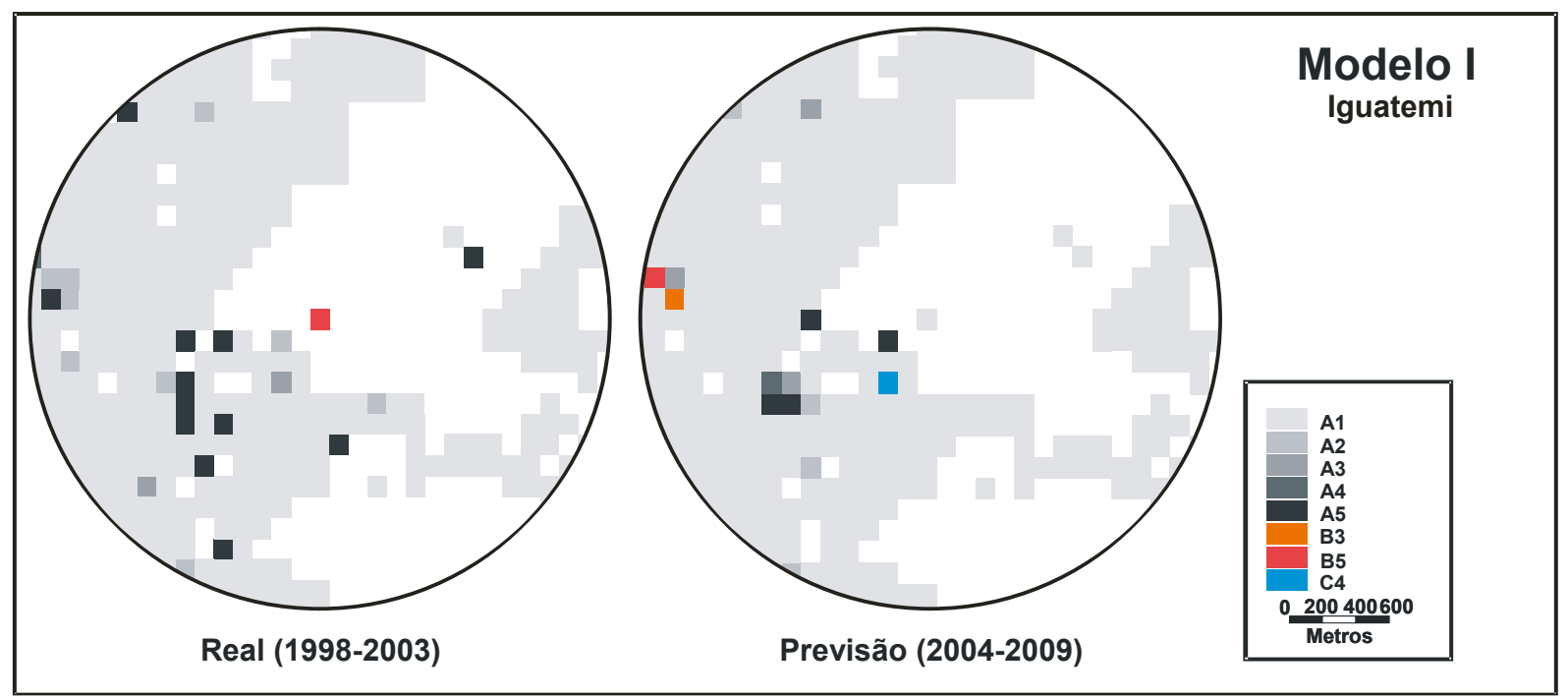

Figura 5.21: Real x Previsão Modelo I - Iguatemi 


\subsubsection{Modelo I - Previsão - ZCN}

Para a análise da previsão do Modelo I para a ZCN foi produzida a Figura 5.22. Pode-se inferir que o modelo, de uma maneira geral, acerta as regiões onde as classes são mais elevadas. Porém, erra nas classes em si e, adicionalmente, produz um incremento nos valores, representado pelas células em verde (E2 e E3).

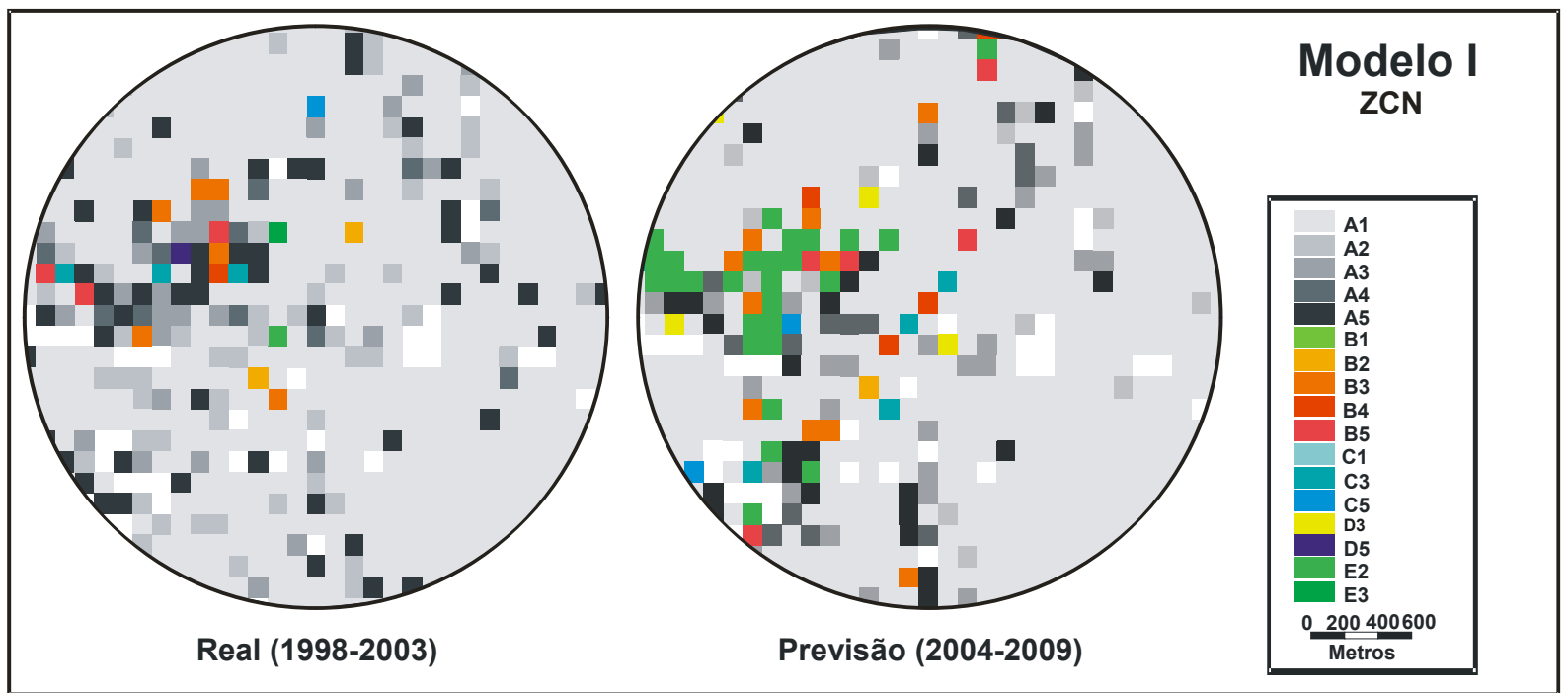

Figura 5.22: Real x Previsão Modelo I - ZCN

\subsection{Modelo II - resultados da previsão para o período 2004-2009}

Para a tentativa de se visualizar o cenário para um período de projeção do futuro, aplicouse o modelo espacial determinado anteriormente para estimar a ocupação comercial no período 2004-2009. O mapa temático segundo as classes de variáveis relacionadas à ocupação comercial para o período 2004-2009 está ilustrado na Figura 5.23. 


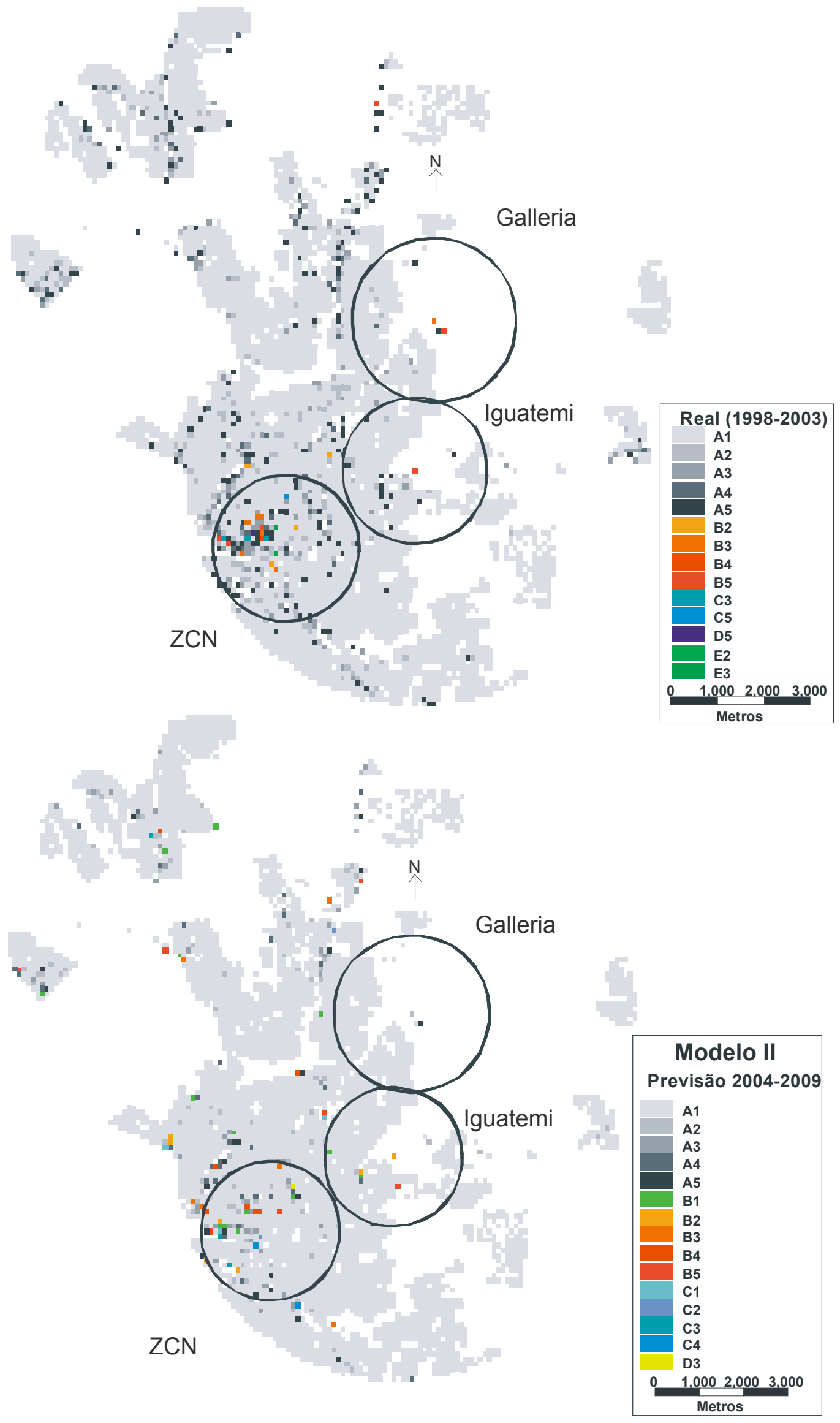

Figura 5.23: Ocupação comercial real x prevista pelo Modelo II no período 2004-2009 
Nos subitens a seguir serão apresentadas as análises dos resultados da previsão realizadas pelo Modelo II para as áreas ao redor dos Shoppings Centers Galleria e Iguatemi, bem como para a região da ZCN.

\subsubsection{Modelo II - Previsão - Shopping Galleria}

A Figura 5.24 mostra a previsão do Modelo II para o Shopping Galleria. Da mesma forma como ocorreu para a fase de validação, o modelo parece não ser capaz de acertar a célula que representa o Shopping em si, pois a classe na situação real atual é B3 e o modelo previu como sendo A2.

Nas duas células bem próximas ao Shopping o modelo erra nas classes, que na situação real é A5 e B5 e na previsão se torna A1 e A5, respectivamente.

Nas zonas periféricas ele não consegue captar nenhuma diferença, classificando todas as células como A1.

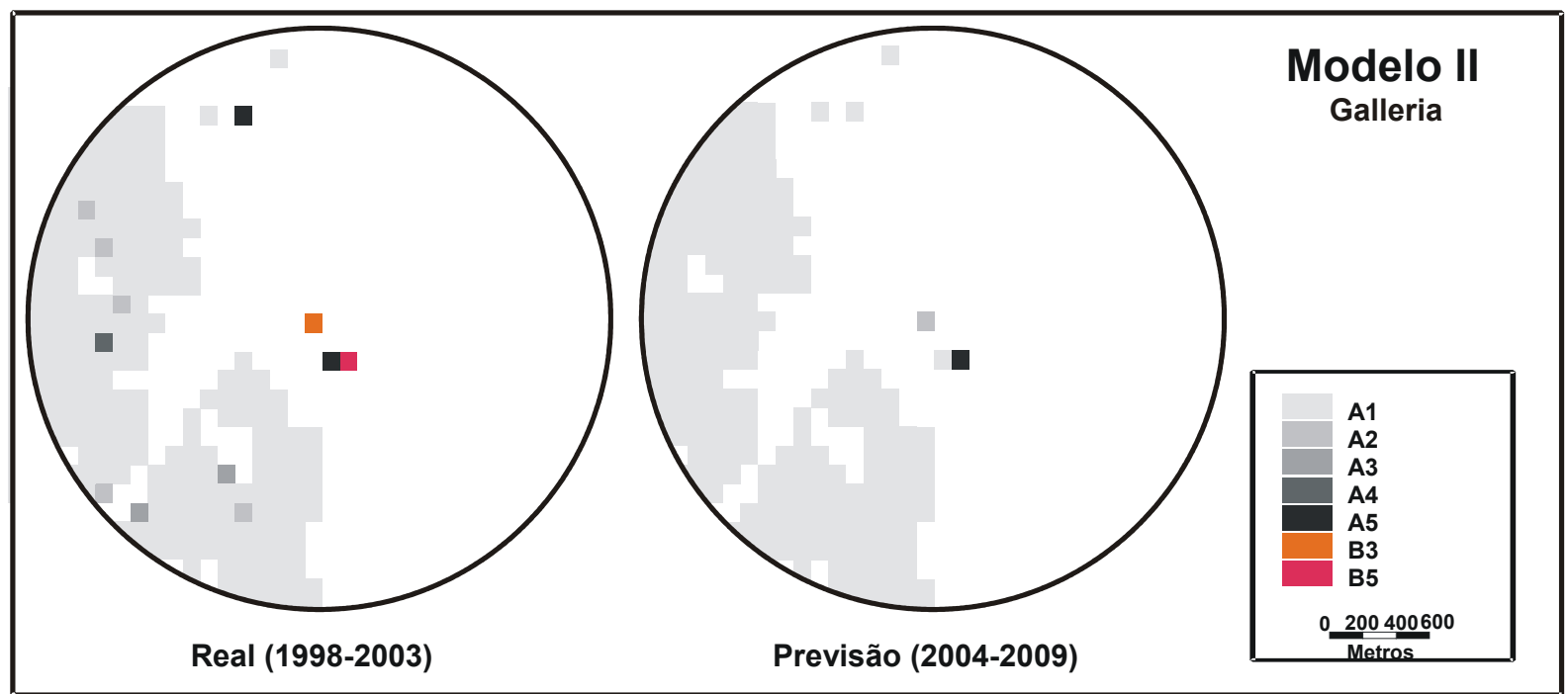

Figura 5.24: Real x Previsão Modelo II - Galleria 


\subsubsection{Modelo II - Previsão - Shopping Iguatemi}

Para a comparação da situação real com a previsão do Modelo II para o Shopping Iguatemi, a Figura 5.25 indica que o valor que representa o shopping foi reduzido de B5 para B2, porém, menos do que observado no Modelo I (que apresentou a classe A1 para a previsão).

Além disso, o modelo captou levemente os locais onde as classes são mais altas, apesar de não acertar exatamente as classes em si. No modelo há a ocorrência de uma célula A4, B1, B2 e B5, enquanto que no caso real há mais classes A5.

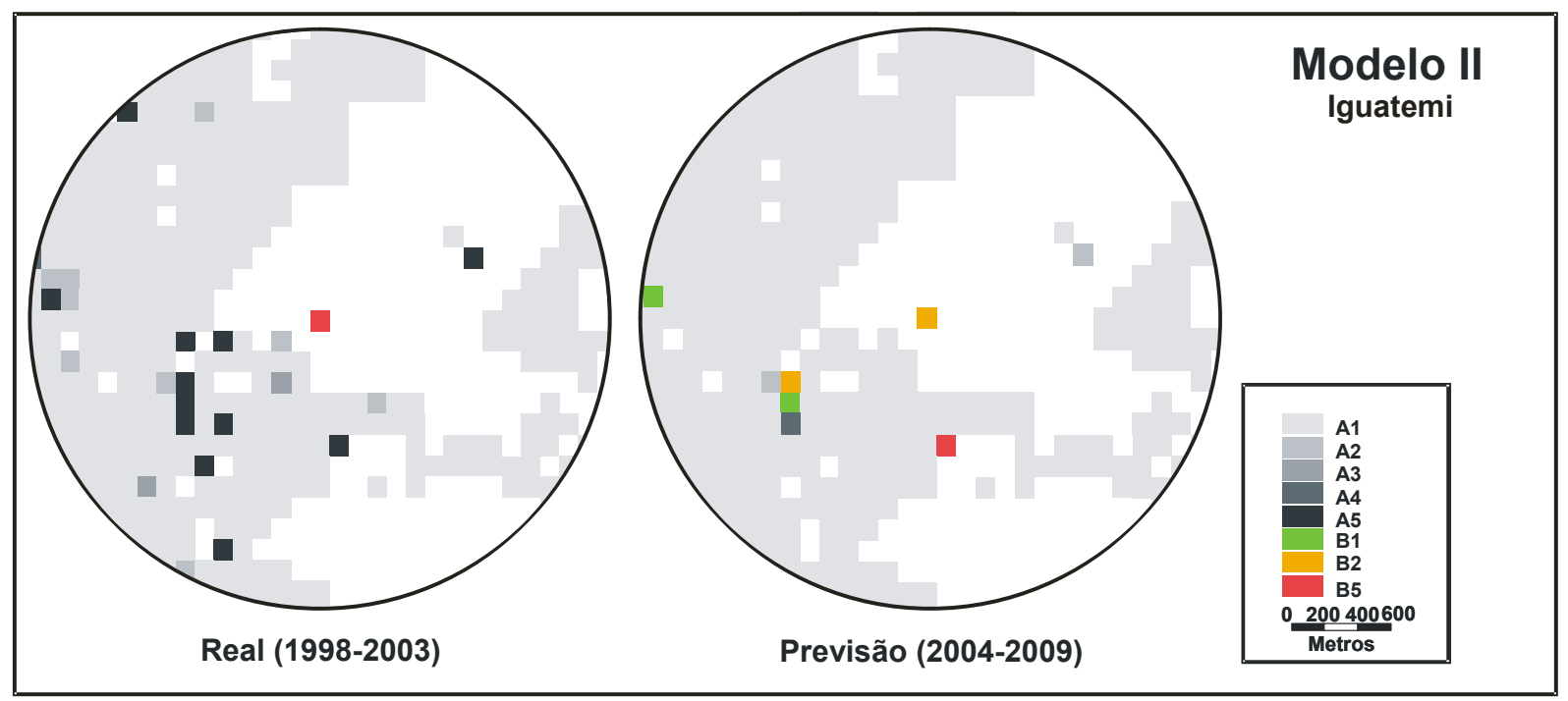

Figura 5.25: Real x Previsão Modelo II - Iguatemi

\subsubsection{Modelo II - Previsão - ZCN}

A análise da previsão do Modelo II para a ZCN é auxiliada através da Figura 5.26. Neste caso, o modelo aparentemente quase não consegue prever as regiões onde as classes são mais elevadas. A previsão é muito diferente do padrão observado na situação real atual. 


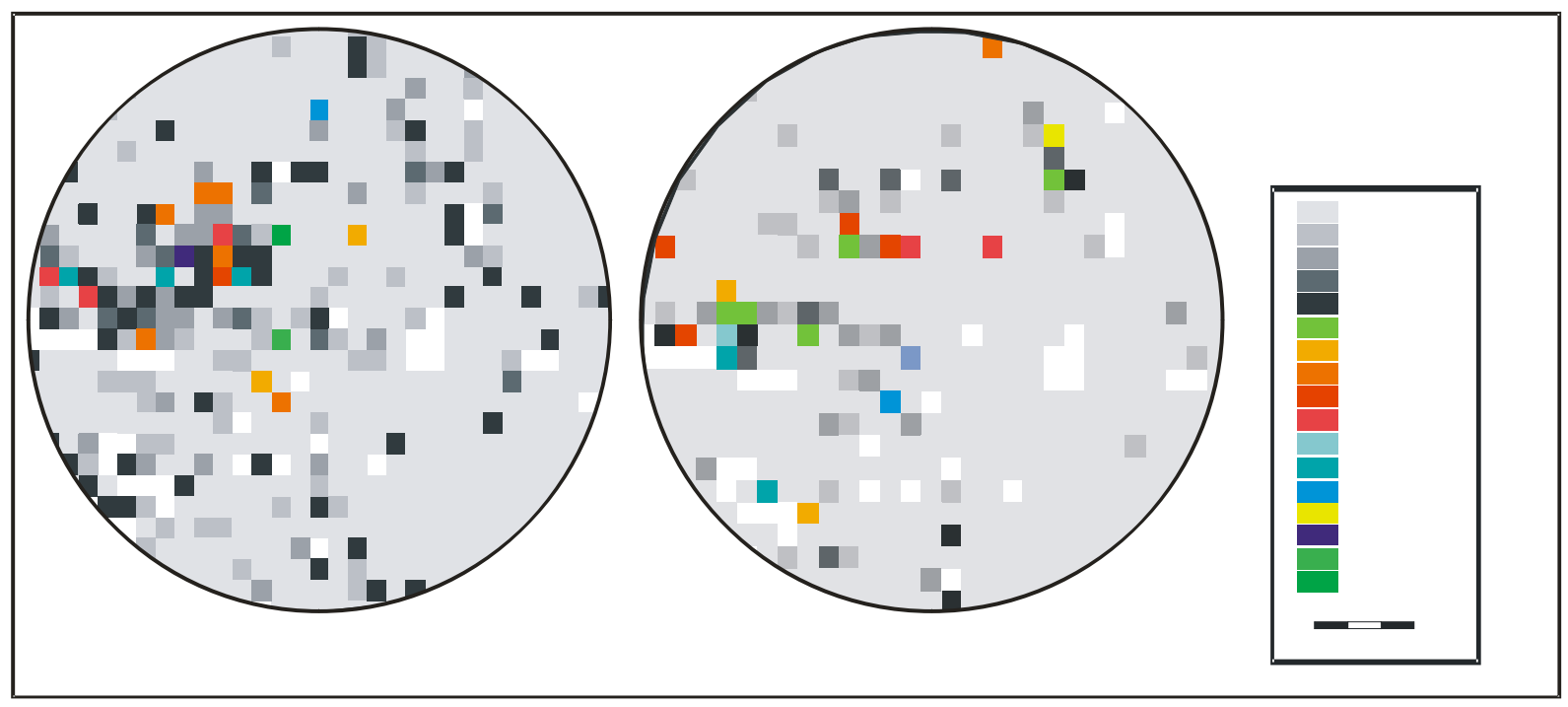

Figura 5.26: Real x Previsão Modelo II - ZCN

\subsection{Discussão final dos resultados}

Para o Modelo I, é apresentada a contagem do número absoluto de unidades comerciais dentro de cada classe da variável proporção de uso comercial para os Shopping Centers estudados, focos do presente estudo. A contagem está representada pelas barras verticais, mostradas nas Figuras 5.27 e 5.28 .

A Figura 5.27 mostra a distribuição de dados ao longo do tempo considerando o Shopping Galleria, e a Figura 5.28 mostra o caso do Shopping Iguatemi. O foco desta análise está voltado para aquelas ocorrências dentro da classe de $80 \%$ a $100 \%$ de proporção de uso comercial, ou seja, aquela que representa os Shopping Centers, pelo seu alto percentual de ocupação.

É importante salientar que a primeira classe (de 0 a 20\%) foi suprimida da análise por conter a grande maioria dos registros, o que dificultaria a interpretação do que ocorre para as 
outras classes. Além disso, não é relevante, neste caso, saber como é o comportamento das regiões que possuem valores baixos para a variável em questão.

Analisando-se a Figura 5.27, que representa o Shopping Galleria para o Modelo I, observase uma diminuição na proporção de uso comercial após 1979, permanecendo estabilizada até 2006, quando voltaria a crescer novamente segundo os resultados de previsão do modelo para 2009. Com relação ao representado pelo Modelo I para o Shopping Iguatemi (Figura 5.28), observa-se um contínuo crescimento no número de ocupações por proporção de uso comercial desde o primeiro período até 2003, sendo a previsão para 2009 apresentada pelo modelo, a de uma estabilização.

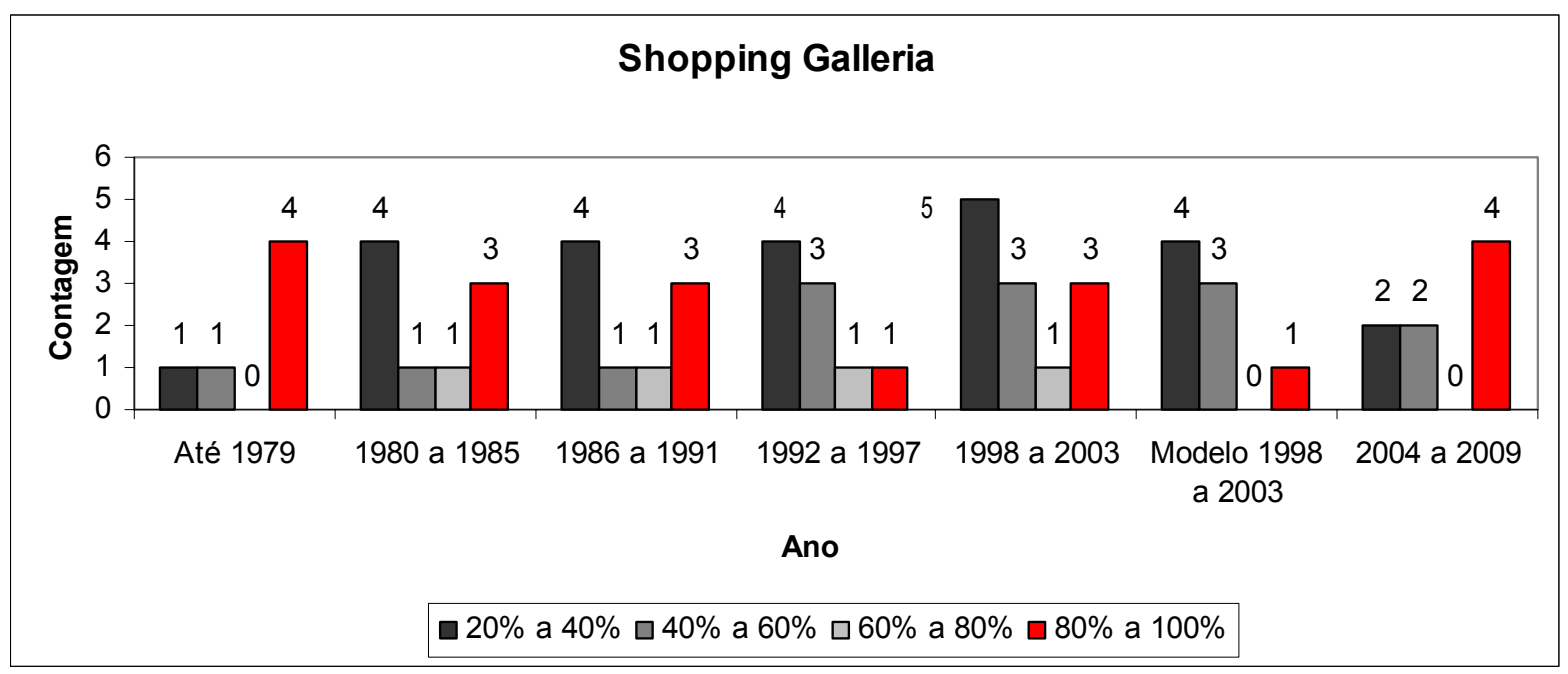

Figura 5.27: Número de ocupações por proporção de uso comercial para o Shopping Galleria - Modelo I

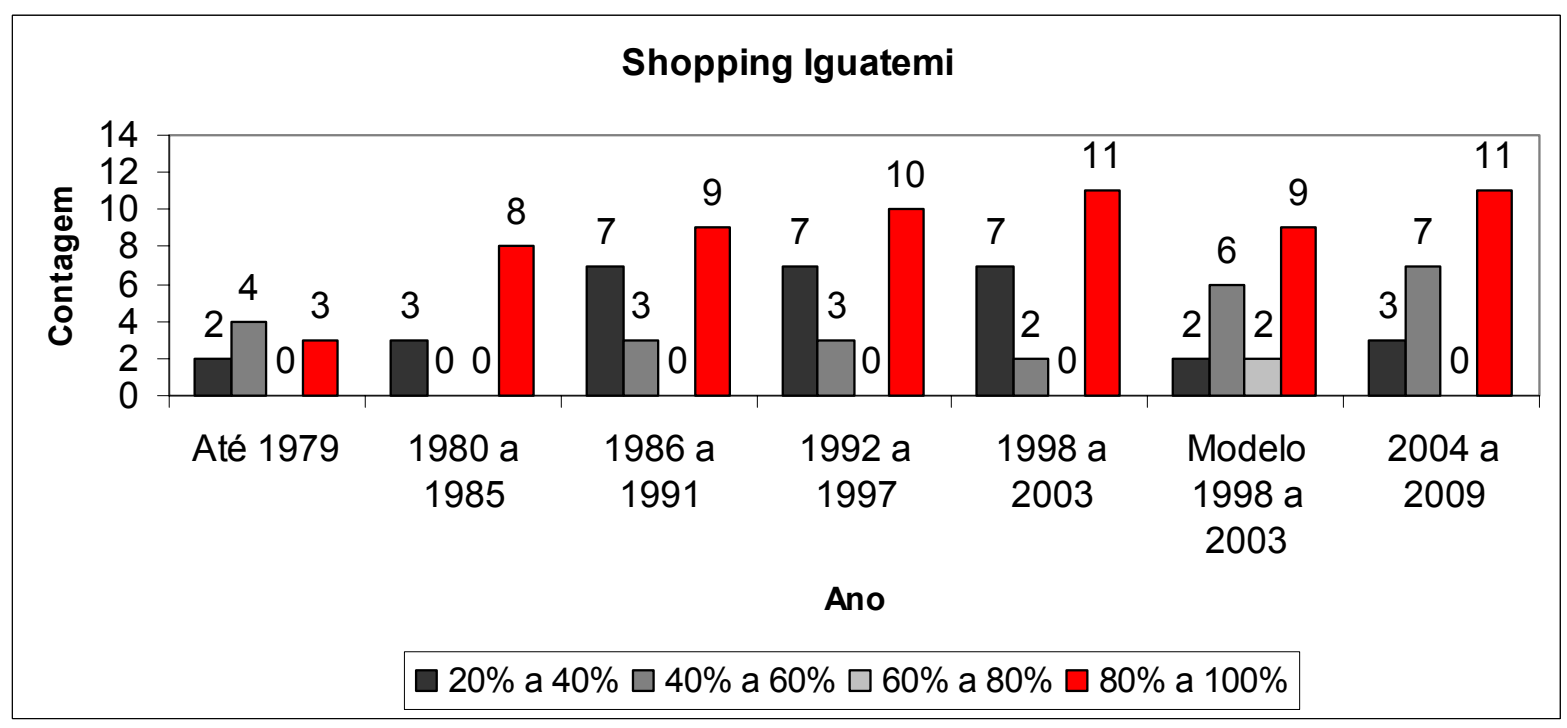

Figura 5.28: Número de ocupações por proporção de uso comercial para o Shopping Iguatemi - Modelo I 
A exemplo do que foi feito para o Modelo I, a análise da contagem do número absoluto de unidades comerciais por classe da variável proporção de uso comercial foi realizada também para o Modelo II.

Analisando-se as Figuras 5.29 e 5.30, que representam os Shoppings Galleria e Iguatemi para o Modelo II, observa-se que, ao julgar pelas tendências observadas nos anos anteriores, o Modelo II não é capaz de estimar o padrão que o Modelo I captou em relação ao crescimento da ocupação comercial ao redor de ambos os Shopping Centers.

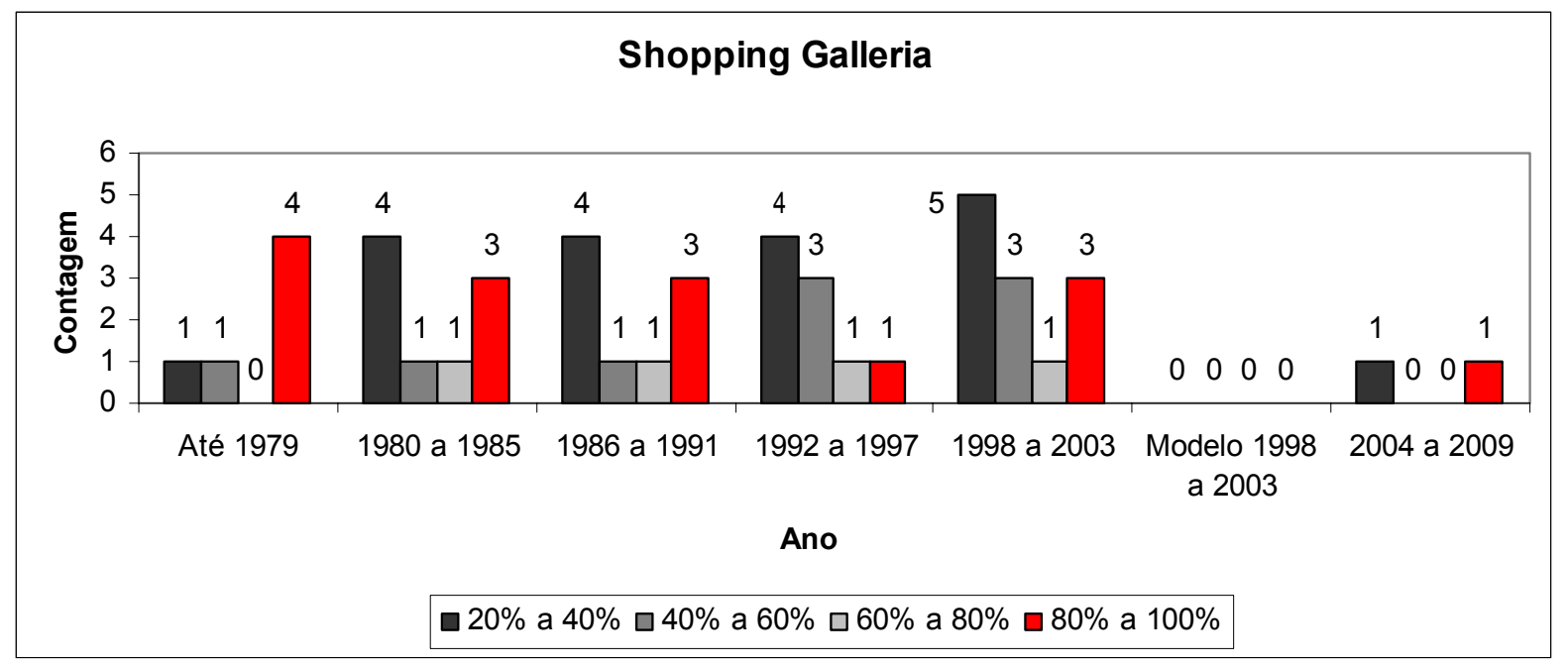

Figura 5.29: Número de ocupações por proporção de uso comercial para o Shopping Galleria- Modelo II

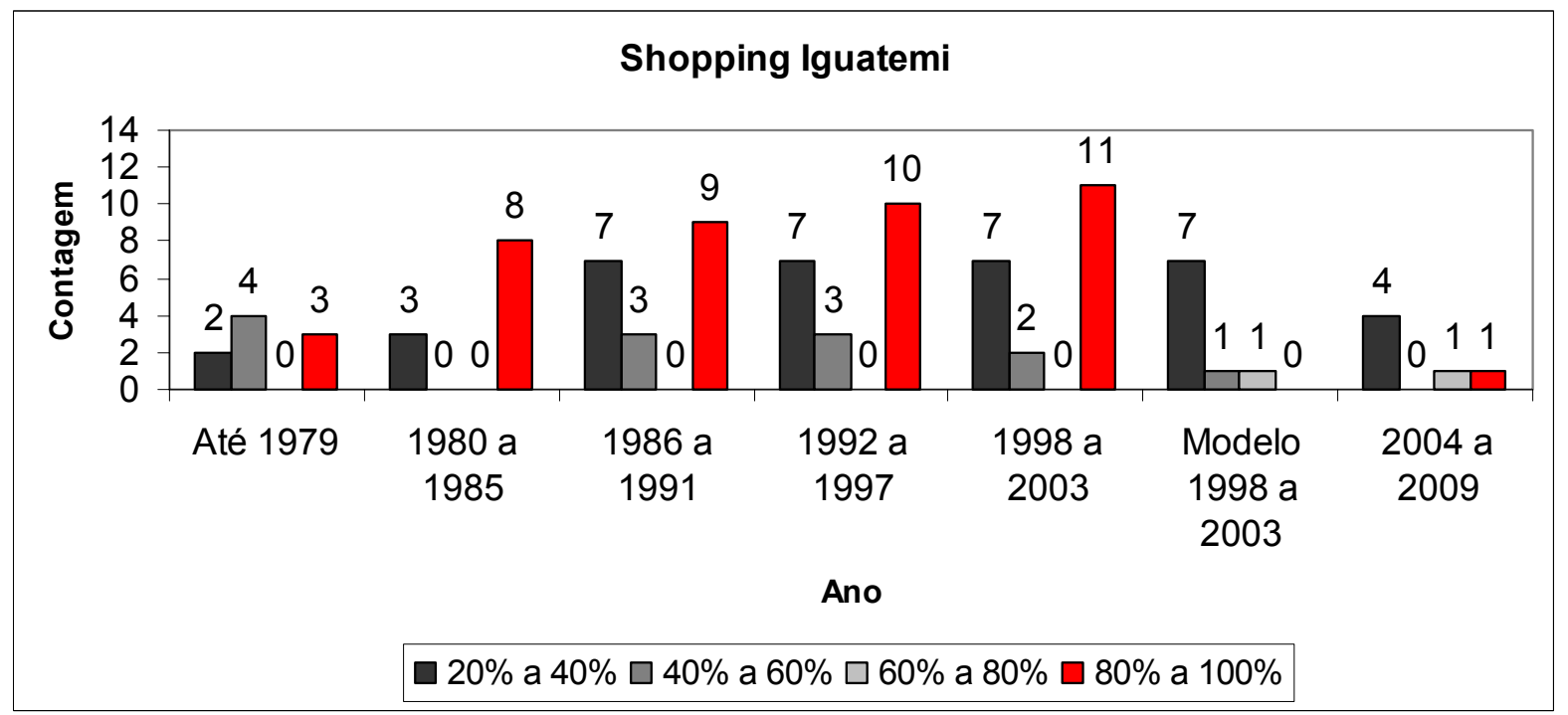

Figura 5.30: Número de ocupações por proporção de uso comercial para o Shopping Iguatemi - Modelo II 
No próximo capítulo são apresentadas as conclusões do presente trabalho, com algumas recomendações e discussões sobre os resultados aqui obtidos. 


\section{Conclusões e recomendações}

Uma vez atingido o primeiro objetivo proposto para esta pesquisa, o de modelar os padrões de crescimento dos PGVs utilizando técnicas de análise e modelagem espacial, foi possível avaliar a hipótese de que Pólos Geradores de Viagens (PGVs) existentes influenciam a localização e o tamanho de novos PGVs. Ao testar essa hipótese em um estudo de caso aplicado na cidade de Campinas, São Paulo, algumas conclusões relevantes foram obtidas.

Primeiro, conforme os resultados obtidos, verifica-se que é possível construir um modelo que represente o crescimento da ocupação comercial ao longo do tempo, a partir de variáveis relativamente fáceis de serem obtidas, e com base somente na localização e no tamanho dos PGVs existentes. O modelo desenvolvido para o caso aqui estudado apresentou um bom ajuste aos dados reais de Campinas.

Analisando-se as distribuições espaciais para os valores da variável de ocupação comercial proporção de uso comercial, por meio de sua representação em mapas temáticos classificados segundo 
quadrantes do gráfico de Moran (ou Box Map), observa-se que é possível caracterizar razoavelmente bem as regiões onde a ocupação comercial é mais ou menos intensa, ao longo dos períodos considerados.

A inserção das variáveis de infra-estrutura viária no modelo desenvolvido no sentido de ampliar a investigação no presente estudo, embora melhore o desempenho do modelo, parece não colaborar na projeção de tendências. Isso pode ser explicado pelo fato de não terem sido obtidas as informações das vias principais por período, somente na situação atual. Com isso, não foi possível o conhecimento da importância de cada via principal na cidade, que, muito provavelmente, acompanharia o crescimento dos usos comerciais observados nos períodos analisados.

Considerando-se os resultados do Modelo I, a previsão da contagem do número absoluto de unidades comerciais por classe da variável proporção de uso comercial aponta para uma manutenção do crescimento ao redor do Shopping Iguatemi e para um ligeiro incremento na classe mais alta (de 80 a 100\%), no caso do Shopping Galleria, embora acompanhada por uma redução nas outras classes. O Modelo II não foi capaz de estimar o padrão que o Modelo I detectou.

O modelo desenvolvido ( $3 \mathrm{IN}, 1$ OUT), tanto com as variáveis introduzidas na primeira parte da pesquisa (Modelo I) como na segunda (Modelo II), não foi capaz de prever alterações nos padrões de uso do solo que impliquem em impactos adicionais imediatos e significativos na infra-estrutura de transportes decorrentes do crescimento de atividades comerciais nas vizinhanças de Pólos Geradores de Viagens. Embora ambos os modelos tenham apresentado 
comportamentos diversos nas previsões, praticamente não apontaram para um crescimento dos PGVs.

Quanto à extrapolação para o período 2004-2009, para as duas situações analisadas (Modelo I e Modelo II), pode-se observar que, para ambas, as células que representam os Shoppings são alteradas para classes mais baixas, enquanto que, muito provavelmente, deveria receber um incremento.

Portanto, a análise das projeções futuras não parece caracterizar adequadamente o impacto do surgimento de novos pólos comerciais ao redor dos Shopping Centers estudados, ainda que, para as regiões de vizinhança, ambos os modelos tenham sido capazes de captar os locais de maior ocorrência de classes mais altas, embora não necessariamente acertando as classes.

Para trabalhos futuros seria interessante que apenas os registros inseridos nas áreas dos PGVs analisados fossem adicionados ao modelo, para que os padrões contidos nessas áreas pudessem ser captados sem a interferência dos padrões de outras regiões. Isso não excluiria a necessidade de se proceder à análise do conjunto total da amostra, uma vez que, quanto mais registros a rede puder utilizar para a fase de treinamento, mais robusto será o modelo. 
De uma maneira geral, a natureza das análises aqui desenvolvidas pode ser útil ao planejamento regional para a previsão de impactos do surgimento de PGVs, dada a inter-relação entre uso e ocupação do solo e oferta de transportes, podendo ser aplicada para outros tipos de uso do solo e talvez também em modelos com combinações de usos (comercial e industrial, por exemplo). Nessa perspectiva, seria fundamental a inclusão de outras variáveis explicativas nos modelos a serem testados, de forma a melhorar a sua capacidade de representação do fenômeno real, na linha em que trabalhou Santos (2005). 


\section{Referências bibliográficas}

ABRASCE (2005) Associação Brasileira de Shopping Centers. Disponível em http://www.abrasce.com.br/. Acesso em 20/12/2005.

ANSELIN, L. (1992) Spatial Data Analysis with GIS: An Introduction to Application in the Social Sciences. Technical Report 92-10, National Center for Geographic Information and Analysis, University of California, Califórnia, EUA, 1992. (Disponível em: www.ncgia.ucsb.edu/Publications/Tech_Reports/92/92-10.PDF. Acesso em: 11 de set. de 2004)

ANSELIN, L. (1995) Local Indicators of Spatial Association - LISA, Geographical Analysis, 27, 93115.

ANSELIN, L. (2003) GeoDa 0.9 User's Guide. Spatial Analysis Laboratory and Center for Spatially Integrated Social Science. University of Illinois, Urbana-Champaign.

ANSELIN, L.; BAO, S. (1997) Exploratory spatial data analysis linking SpaceStat and ArcView. In: FISHER M.; GETIS, A. (Eds.) Recent Developments in Spatial Analysis. Berlin: Springer-Verlag, 1997. 
ANSELIN, L.; SMIRNOV, O. (1998) The SpaceStat Extension for ArcView 3.0. Regional Research Institute, West Virginia University, Morgantown.

ANTP (1999) Circulação com qualidade na cidade do século XXI. Associação Nacional de Transportes Públicos. São Paulo.

ANTP (2005) Planejando o desenvolvimento das Cidades. Associação Nacional de Transportes Públicos. São Paulo. Disponível em: http://www.antp.org.br/telas/desenvolvimento_urbano.htm

ARY, M. B. (2002) Análise da Demanda de Viagens Atraídas por Shopping Centers em Fortaleza. Dissertação de Mestrado. Programa de Engenharia de Transportes. Universidade Federal do Ceará, UFC, Brasil.

BIENENSTEIN, G. (1993) Capital e Espaşo Urbano: O Exemplo do Shopping Center. Dissertação de Mestrado. Departamento de Geografia. Universidade Federal do Rio de Janeiro, UFRJ, Brasil.

CÂMArA, G.; CARvalHO, M.S., CRUZ, O.G., CORREA, V. (2002a) Análise Espacial de Áreas. In: Análise Espacial de Dados Geográficos, eds. FUCKS, S.D., CARVALHO, M.S., CÂMARA, G., MONTEIRO, A.M.V. Divisão de Processamento de Imagens - Instituto Nacional de Pesquisas Espaciais, São José dos Campos, São Paulo. Disponível em: www.dpi.inpe.br/gilberto/livro/analise/

CÂMARA, G.; MONTEIRO, A.M.; FUCKS, S.D.; CARVALHO, M.S. (2002b) Análise Espacial e Geoprocessamento. In: Análise Espacial de Dados Geográficos, eds. FUCKS, S.D., CARVALHO, M.S., CÂMARA, G., MONTEIRO, A.M.V. Divisão de Processamento de Imagens - Instituto 
Nacional de Pesquisas Espaciais, São José dos Campos, São Paulo. Disponível em: www.dpi.inpe.br/gilberto/livro/analise/

CARSJENS, G. J., LIGTENBERG, A. (2006) A GIS-based support tool for sustainable spatial planning in metropolitan areas. Landscape and Urban Planning 80 p. 72-83.

CASELLO, J. M. (2006) Transit competitiveness in polycentric metropolitan regions. Transportation Research Part A 41 p. 19-40.

CET (1983) Companhia de Engenharia de Tráfego. Pólos Geradores de Tráfego. Boletim Informativo $n^{\circ}$ 32. Prefeitura de São Paulo, São Paulo.

CHENG, E. W. L., LI, H., YU, L. (2005) A GIS approach to shopping mall location. Building and Environment 42 p. 884 - 892.

DENATRAN (2001) Manual de Procedimentos para o Tratamento de Pólos Geradores de Tráfego. Departamento Nacional de Trânsito, Ministério da Justiça, Brasília, DF.

ESPEJO, C.P.L. (2001) Estimación de tasas de generación de viajes para actividades comerciales en el A.M.C.: Propuesta Metodológica. Dissertação de Mestrado, Universidad Simon Bolívar, Caracas, Venezuela.

FARAWAY, J., CHATFIELD, C. (1995) Time series forecasting with neural networks: a case study. London, UK. Research Report 95-06, University of Bath, 20p. 
FRÚGOLI JR., H. (1998) Os Shopping Centers e o impacto nas cidades de médio porte. In: Boletim de Conjuntura de Araraquara, p. 50 - 52. $1^{\circ}$ nov. 1998. Faculdade de Ciências e Letras, UNESP, Araraquara.

GIUSTINA, C.D.; CYBIS, H.B.B (2003) Metodologias de análise para estudos de impactos de Pólos Geradores de Tráfego. In: III Semana de Produção e Transportes, Universidade Federal do Rio Grande do Sul, UFRGS, Rio Grande do Sul. Disponível em: http://www.producao.ufrgs.br/dissert_mestrado/art_cybis30.pdf

GRANDO, L. (1986) A interferência dos pólos geradores de tráfego no sistema viário: análise e contribuição metodologica para Shopping Centers. Dissertação de Mestrado. Programa de Engenharia de Transportes, COPPE/ Universidade Federal do Rio de Janeiro, RJ.

GOLDNER, L.G., PORTUGAL, L.S. (1993) Metodologia de Avaliação de Impactos de Tráfego de Shopping Centers: Uma Abordagem Multimodal. In: Anais eletrônicos do VII Congresso de Pesquisa e Ensino em Transportes, ANPET, 1993, São Paulo.

GREENWALD, M. J. (2006) The relationship between land use and intrazonal trip making behaviors: Evidence and implications. Transportation Reserch Part D 11 p. 432-446.

GRIGOLON, A. B.; MANZATO, G. G.; SILVA, A. N. R. (2007) Spatial growth patterns and transportation impacts of major trip generators - the case of Campinas, Brazil. Artigo aceito para a World Conference on Transport Research Society, a ser realizada em Berkeley, Califórnia, EUA. 
GRIGOLON, A.B., SILVA, A.N.R. (2006) Impactos dos padrões de ocupação do solo no entorno de Pólos Geradores de Viagens. In: Anais eletrônicos do XX Congresso de Pesquisa e Ensino em Transportes, ANPET, Brasília, Brasil.

KABOS, S.; CSILLAG, F. (2002) The analysis of spatial association on a regular lattice by joincount statistics without the assumption of first-order homogeneity. Computers \& Geosciences, n. 2, p. 7-35.

KAMPEL, S. A.; CÂMARA, G.; QUINTANILHA, J. A. (2000) Análise exploratória das relações espaciais do desflorestamento na Amazônia legal brasileira. In: Anais do GIS Brasil 2000. Disponível em: www.dpi.inpe.br/gilberto/

KNEIB, E.C. (2004) Caracterização de empreendimentos geradores de viagens: contribuição conceitual à análise de seus impactos no uso, ocupação e valorização do solo urbano. Dissertação de Mestrado em Transportes. Universidade de Brasília. UNB.

KREMPI, A.P. (2004) Explorando recursos de estatística espacial para análise da acessibilidade da cidade de Bauru. Dissertação de Mestrado, Escola de Engenharia de São Carlos, Universidade de São Paulo. São Carlos, São Paulo.

LABHOUET, R.A., BRUNA, G.C. (1991) Atividade terciária e o espaço urbano: shopping center. Trabalho de Conclusão de Curso. Faculdade de Arquitetura e Urbanismo, Universidade de São Paulo, SP. 
LEMOS, D. S. C. P. S; SANTOS, M. P. S.; PORTUGAL, L. S. (2004) Análise da relação entre o sistema de transporte e a exclusão social na cidade do Rio de Janeiro. Revista Engevista, v. 6, n. 3, p. 36-53, 2004.

LEMOS, D. S. C. P. S; SANTOS, M. P. S.; PORTUGAL, L. S. (2005) Análise das relações existentes entre o uso do solo e o sistema de transportes, na cidade do Rio de Janeiro, Brasil. In: Anais eletrônicos do $1^{\circ}$ Congresso Luso-Brasileiro para o Planejamento Urbano Regional Integrado Sustentável, PLURIS 2005, São Carlos, Brasil, 2005.

LEMOS, D. S. C. P. S; SANTOS, M. P. S.; PORTUGAL, L. S. (2006) Acessibilidade e desenvolvimento na região norte fluminense, RJ, Brasil. In: Anais eletrônicos do XIV Congreso Panamericano de Ingeniería de Tránsito y Transporte, PANAM, Las Palmas, Espanha, 2006.

LOPES, S. B. (2005) Estudo da Dependência Espacial em Modelos de Previsão de Demanda por Transporte. Dissertação de Mestrado, Escola de Engenharia de São Carlos, Universidade de São Paulo. São Carlos, São Paulo.

MANZATO, G. G. (2007) Regiões Urbanas Homogêneas e Oferta de Transportes. Dissertação de Mestrado, Escola de Engenharia de São Carlos, Universidade de São Paulo. São Carlos, São Paulo,

MANZATO, G. G.; SILVA, A. N. R. (2006) Incorporando um indicador de oferta de infraestrutura de transportes na definição de regiões metropolitanas. In: Anais eletrônicos do XX Congresso de Pesquisa e Ensino em Transportes, ANPET, Brasília, Brasil. 
MANZATO, G. G.; SOARES, A. J.; SILVA A. N. R. (2006) Aglomerações urbanas e oferta de transportes no estado de São Paulo, Brasil. In: Anais eletrônicos do $2^{\circ}$. Congresso Luso-Brasileiro para o Planeamento Urbano Regional Integrado Sustentável, PLURIS 2006, Braga, Portugal.

MASANO, T.F. (1993) Os Shopping Centers e suas relações físico-territoriais e sócio-negociais no município de São Paulo. Tese de Doutorado, Faculdade de Arquitetura e Urbanismo, Universidade de São Paulo. São Paulo.

MELO Jr., Y. P., MONETTI, E. (2004) A importância na escolha do local de implantação para um shopping center. In: CLACS'04 - I Conferência Latino-Americana de Construção Sustentável / ENTAC'04 - 10. Encontro Nacional de Tecnologia do Ambiente Construido. Escola Politécnica, Departamento de Engenharia de Construção Civil, Universidade de São Paulo, Brasil.

MODES, E.C, VARGAS, H.C. (1987) Impacto de Shopping Centers. Trabalho de Conclusão de Curso. Graduação em Arquitetura e Urbanismo. Universidade de Guarulhos.

MONTESSORO, C. C. L. (2000) Os Shopping Centers e as estratégias de localização. In: $2^{a}$ Semana de Geografia, Presidente Prudente. UNESP - Universidade Estadual Paulista. Presidente Prudente, SP.

NEVES, M.C, RAMOS, F.R, CAMARGO, E. C. G., CÂMARA, G., MONTEIRO, A.M. (2000) Análise espacial de dados sócio-econômicos de São Paulo. Disponível em www.dpi.inpe.br/gilberto/ papers/marcos_gisbrasil2000.pdf. Acesso em 15/11/2005. 
ORFORD, S. (2004) Identifying and comparing changes in the spatial concentrations of urban poverty and affluence: a case study of inner London. Computers, Environment and Urban Systems, v. 28, n. 6, p. 701-717.

PAEZ, A. (2006) Exploring contextual variations in land use and transport analysis using a probit model with geographical weights. Journal of Transport Geography 14 p. 167 - 176.

PEDROSA, B. M.; CÂMARA, G. (2002) Modelagem Dinâmica e Geoprocessamento, In: Análise Espacial de Dados Geográficos, eds: Fucks, S. D.; Carvalho, M. S.; Câmara, G.; Monteiro, A. M. V. Divisão de Processamento de Imagens - Instituto Nacional de Pesquisas Espaciais, São José dos Campos, São Paulo. Disponível em: www.dpi.inpe.br/gilberto/livro/analise/

PING, J. L.; GREEN, C. J.; ZARTMAN, R. E.; BRONSON, K. F. (2004) Exploring spatial dependence of cotton yield using global and local autocorrelation statistics. Field Crops Research, v. 89, p. 219-236.

PORTUGAL, L. S.; GOLDNER, L. G. (2003) Estudo de Pólos Geradores de Tráfego e de seus impactos nos sistemas viários e de transportes. $1^{\mathrm{a}} \mathrm{ed}$, Ed. Edgard Blücher Ltda, São Paulo.

PREFEITURA MUNICIPAL DE CAMPINAS. Disponível em www.campinas.sp.gov.br. Acesso em 14/03/2006.

PREMO, L. S. (2004) Local spatial autocorrelation statistics quantify multi-scale patterns in distributional data: an example from the Maya Lowlands. Journal of Archaeological Science, v. 31, n. 7, p. $855-866$. 
QUEIROZ, M. P. (2003) Análise Espacial dos Acidentes de Trânsito do Município de Fortaleza. Dissertação (Mestrado) - Universidade Federal do Ceará, Fortaleza.

RAMOS, R. A. R.; SILVA, A. N. R. (2002) Oportunidades e desafios de técnicas emergentes para o Planeamento Urbano: o caso dos modelos de Cellular Automata. In: VII Encontro de Utilizadores de Informação Geográfica, ESIG 2002, Lisboa, Portugal.

RAMOS, R. A. R.; SILVA, A. N. R. (2003a) A data-driven approach for the definition of metropolitan regions. In: Anais eletrônicos do VIII International Conference on Computers in Urban Planning and Urban Management, CUPUM, Sendai, Japão.

RAMOS, R. A. R.; SILVA, A. N. R. (2003b) Um contributo para a delimitação da área metropolitana do noroeste de Portugal. Revista Portuguesa de Estudos Regionais, p. 61-82.

RAMOS, R. A. R.; SILVA, A. N. R. (2007) A spatial analysis approach for the definition of metropolitan regions - the case of Portugal. Environment and Planning B, v. 34, n. 1, p. 171-185, 2007.

RAMOS, R. A. R.; SILVA, A. N. R.; MIRANDA, V. P. (2004) A comparison of two methods for the definition of regional metropolitan areas through an application in the north of Portugal. In: Anais eletrônicos do $44^{\text {th }}$ European Congress of the European Regional Science Association, Porto, Portugal.

RUMELHART, D. E.; HINTON, G. E.; WILLIAMS, R. J. (1986) Learning internal representations by error propagation. $1^{\text {a }}$ Edition, MIT Press, Cambridge, MA, USA. 
SANTOS, V. S. (2005) Modelagem da Dinâmica Populacional Intra-Urbana com Cellular Automata e Avaliação Multicritério para Antecipar Necessidades de Transportes. Dissertação (Mestrado) - Escola de Engenharia de São Carlos, Universidade de São Paulo, São Carlos, 2005.

SCARLATO, F.C. (1989) Metropolização de São Paulo e o Terceiro Mundo. 2ª.ed., Editora Iglu, São Paulo.

SILVA, E. A. (2002) Cenários da expansão urbana na área metropolitana de Lisboa. Revista de Estudos Regionais - Região Lisboa e Vale do Tejo, n. 5, p. 23-41.

SILVA, M. A. S. (2004) Mapas Auto-Organizáveis na Análise Exploratória de Dados Geoespaciais Multivariados. Dissertação (Mestrado) - Instituto Nacional de Pesquisas Espaciais, São José dos Campos.

SILVA, A. N. R.; RAMOS, R. A. R.; SOUZA, L. C. L.; RODRIGUES, D. S.; MENDES, J. F. G. (2004) SIG - Uma Plataforma para Introdução de Técnicas Emergentes no Planejamento Urbano, Regional e de Transportes: Uma Ferramenta 3D para Análise Ambiental Urbana, Avaliação Multicritério, Redes Neurais Artificiais. São Carlos: Edição dos autores.

SILVA, A. A.; VALA, F. (2001) Acessibilidades e construção na área metropolitana de Lisboa, 1991-2001. Revista de Estudos Regionais - Região Lisboa e Vale do Tejo, n. 3, p. 25-40, 2001.

SILVEIRA, I.T. (1991) Análise de Pólos Geradores de Tráfego Segundo sua Classificação, Área de Influência e Padrões de Viagem. Dissertação de Mestrado. COPPE, Universidade Federal do Rio de Janeiro, UFRJ, Rio de Janeiro. 
TEIXEIRA, G. L. (2003) Uso de Dados Censitários para Identificação de Zonas Homogêneas para Planejamento de Transportes Utilizando Estatística Espacial. Dissertação (Mestrado) - Faculdade de Tecnologia, Universidade de Brasília, Brasília.

TAYLOR, C. E. (1992) "Fleshing Out" Artificial Life II. In: Artificial Life, Santa Fe, New Mexico: p. 25-38.

VARGAS, H.C. (1993a) Comércio: localização estratégica on estratégia na localização? Tese de Doutorado, Faculdade de Arquitetura e Urbanismo, Universidade de São Paulo. São Paulo.

VARGAS, H.C. (1993b) Shopping centers: novas relações entre a atividade comercial e o espaço urbano. In: Encontro Nacional da Anpur, Belo Horizonte.

VIHER, B., DOBNIKAR, A.; D. ZAZULA, (1998) Cellular Automata and Follicle Recognition Problem and Possibilities of Using Cellular Automata for Image Recognition Purposes. International Journal of Medical Informatics, v. 49, p. 231-241.

WEDAGAMA, D. M. P., BIRD, R. N., METCALFE, A. V. (2005) The influence of urban landuse on non-motorised transport casualties. Accident Analysis and Prevention 38 p. 1049-1057.

WHITE, R.; ENGELEN, G. (2000) High-resolution integrated modelling of the spatial dynamics of urban and regional systems. Disponível em: www.elsevier.com/locate/compenvurbsys 
YANG, C., WANG, H.Y.G.Z. (2002) Cellular Automata Modeling in Edge Recognition. Proceedings of the Seventh International Symposium on Artificial Life and Robotics, Japan. Disponível em: http://www.cs.ubc.ca/ cyang/files/publications/AROB_CA $\% 20$ modeling $\% 20$ in $\% 20$ edge $\% 20$ r ecognition_.pdf.

YU, B., YANG, Z., CHENG, C. (2006) Optimizing the distribution of shopping centers with parallel genetic algorithm. Engineering Applications of Artificial Intelligence 20 p. 215-223..

YRIGOYEN, C.C. (2005) Métodos gráficos del análisis exploratorio de datos Espaciales. Instituto L.R. Klein-Dpto. de Economia Aplicada. Universidad Autónoma de Madrid. Dissertação de Mestrado. Disponível em www.uam.es/personal_pdi/economicas/coro/investigacion/aede03.pdf. Acesso em 20/12/2005. 